\title{
Methodology for Applying Monitored Natural Attenuation to Petroleum Hydrocarbon-Contaminated Ground-Water Systems with Examples from South Carolina
}

Water-Resources Investigations Report 00-4161 


\section{Methodology for Applying Monitored Natural Attenuation to Petroleum Hydrocarbon-Contaminated Ground-Water Systems with Examples from South Carolina}

By Francis H. Chapelle, John F. Robertson, James E. Landmeyer, and Paul M. Bradley

U.S. Geological Survey

Water-Resources Investigations Report 00-4161

Prepared in cooperation with the

South Carolina Department of Health and Environmental Control

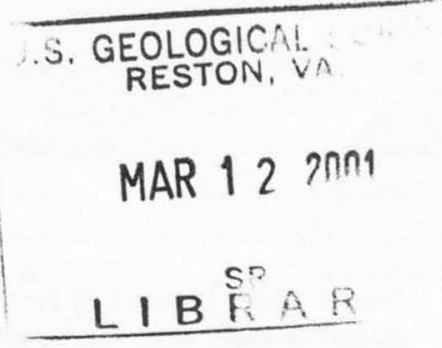

Columbia, South Carolina 2000 


\section{U.S. DEPARTMENT OF THE INTERIOR \\ BRUCE BABBITT, Secretary}

U.S. GEOLOGICAL SURVEY

Charles G. Groat, Director

Use of trade, product, or firm names in this publication is for descriptive purposes only and does not imply endorsement by the U.S. Geological Survey.

For additional information write to:

District Chief

U.S. Geological Survey 720 Gracern Road

Columbia, SC 29210-7651
Copies of this report can be purchased from:

U.S. Geological Survey

Branch of Information Services

Box 25286

Denver, CO 80225

888-ASK-USGS

Additional information about water resources in Florida is available on the World Wide Web at http://sc.water.usgs.gov 


\section{CONTENTS}

Abstract

Introduction

Processes that Contribute to the Natural Attentuation of Petroleum Hydrocarbons ......

Biodegradation

Aerobic Oxidation

Anaerobic Oxidation

Biodegradation of Methyl Tert-Butyl Ether.

Sorption Processes

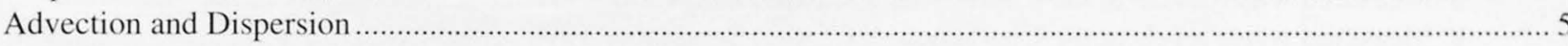

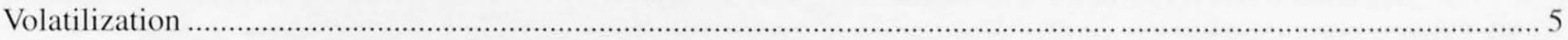

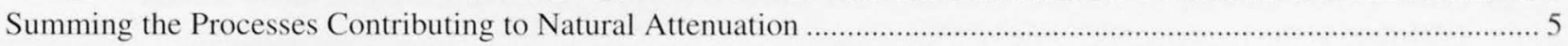

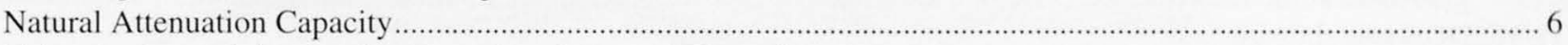

Quantifying the Natural Attenuation Capacity of Ground-Water Systems.................................................................. 8

Estimating Ground-Water Velocity and Hydrodynamic Dispersion ................................................................ 8

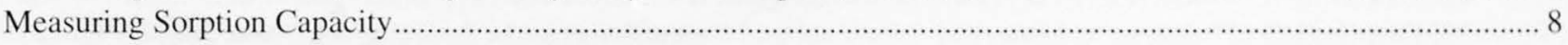

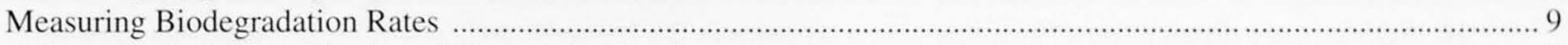

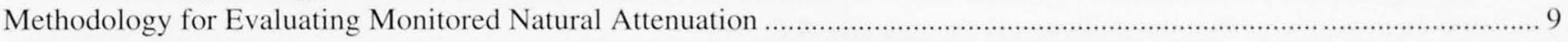

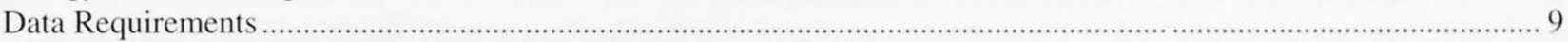

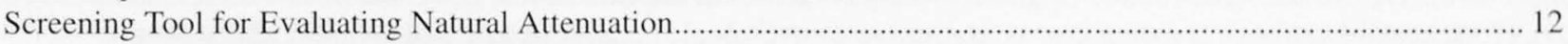

Application of Natural Attenuation Methodology to Two Sites in South Carolina......................................................... 13

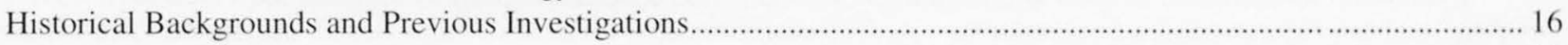

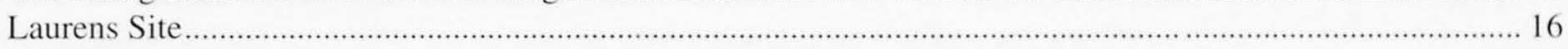

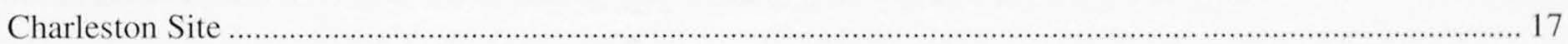

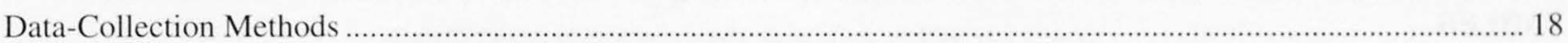

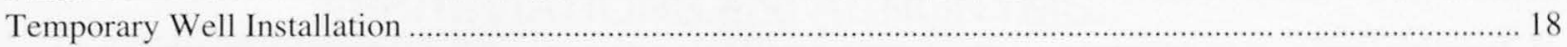

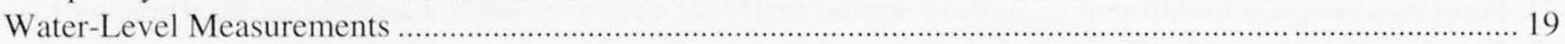

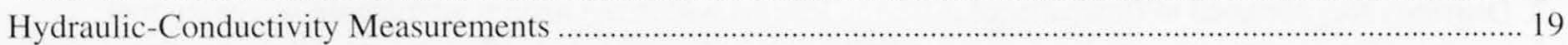

Gasoline-Range Organics Measurements in Soils and Sediments............................................................ 19

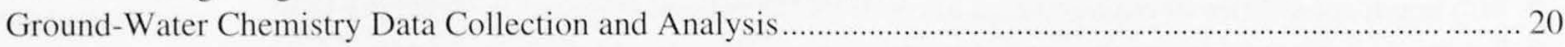

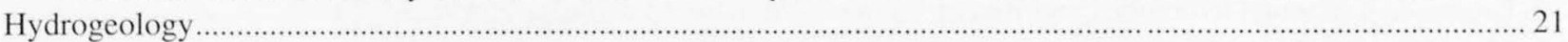

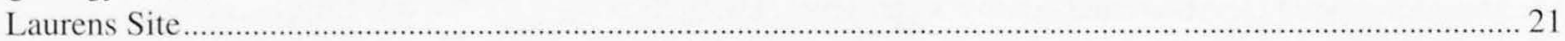

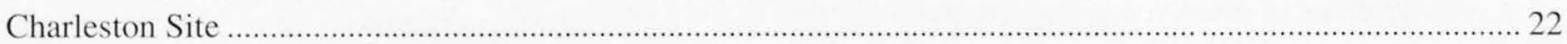

Distribution of Petroleum Hydrocarbons in Sediments and Ground Water ............................................................ 26

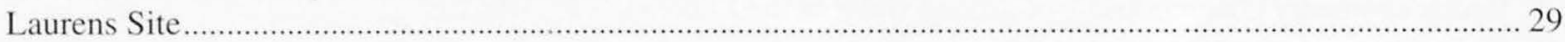

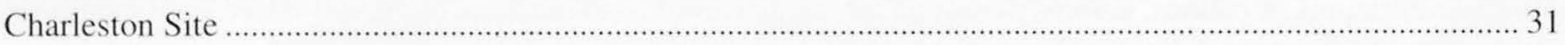

Natural Attenuation of Petroleum Hydrocarbons in Ground Water.................................................................... 36

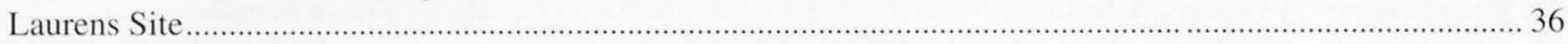

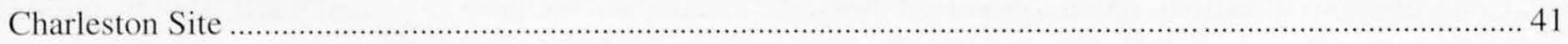

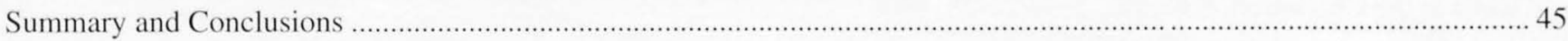

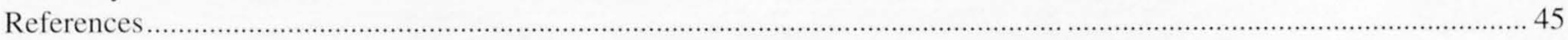




\section{FIGURES}

1. Graphs showing effect of natural attenuation capacity and source-area concentrations on the distance required to decrease contaminant concentrations below maximum contaminant levels .......................................................

2. Diagram of methodology for evaluating monitored natural attenuation............................................................... 10

3. Graph showing effect of natural attenuation capacity on contaminant concentration declines with

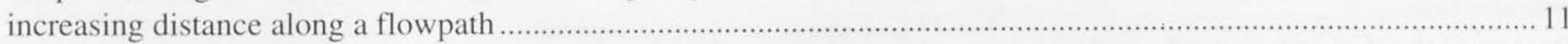

4-9. Maps showing:

4. Study area and location of wells and boreholes at the Laurens, S.C., site …............................................... 14

5. Study area and location of wells and boreholes at the Charleston, S.C., site ………….................................... 15

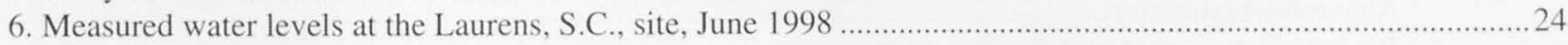

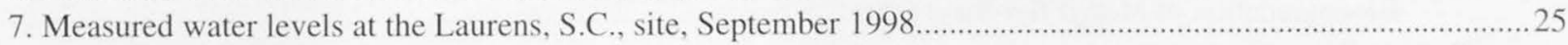

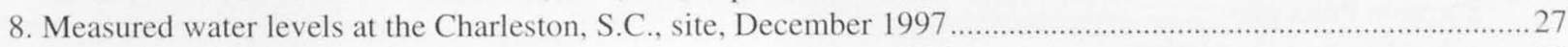

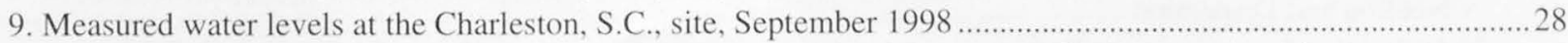

10. Cross section showing the vertical distribution of gasoline-range organics in sediments along section

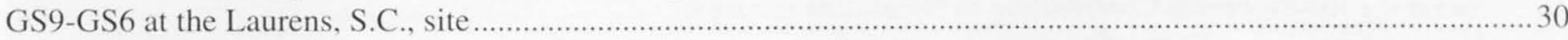

11-16. Diagrams showing

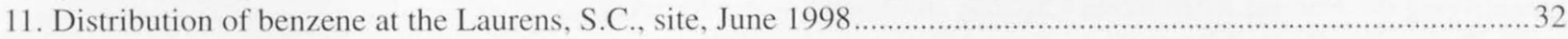

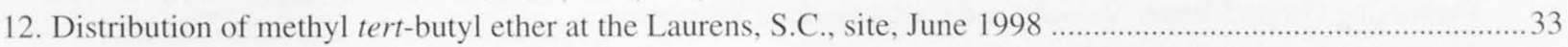

13. Distribution of benzene, toluene, ethylbenzene, and total xylenes at the Laurens, S.C., site, June 1998................34

14. Approximate distribution of gasoline-range organics at the Laurens, S.C., site ................................................... 37

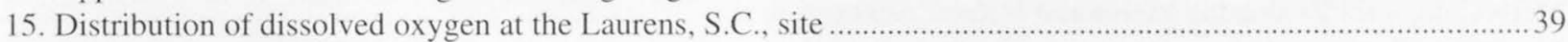

16. Approximate distribution of gasoline-range organics at the Charleston, S.C., site ………................................ 42

17. Schematic diagram showing conceptualization of hydrologic conditions and mobilization of petroleum

hydrocarbons entrained in soils at the Charleston, S.C., site

\section{TABLES}

1. Porosities assigned to different textures of aquifer materials within the natural attenuation screening tool .................. 13

2. Dispersivities assigned to flowpaths of differing lengths within the natural attenuation screening tool ........................ 13

3. Biodegradation-rate constants assigned for different redox conditions within the natural attenuation screening tool ..... 13

4. Maximum solubilities of contaminants allowed by the natural attenuation screening tool ..................................... 13

5. Estimated horizontal hydraulic conductivity values at the Laurens and Charleston, S.C., sites............................... 16

6. Measuring-point elevations and relative water-level elevations at the Laurens, S.C., site ......................................23

7. Concentrations of dissolved petroleum hydrocarbons at the Laurens, S.C., site .................................................31

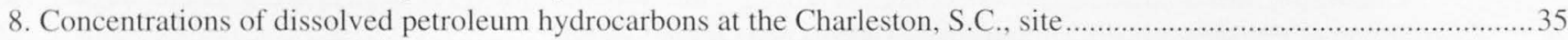

9. Redox chemistry characteristics of ground water at the Laurens, S.C., site ..................................................... 38

10. Concentrations of cations, anions, dissolved inorganic carbon, and methane in ground water from monitoring

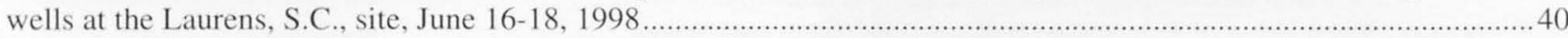

11. Redox chemistry characteristics of ground water at the Charleston, S.C., site .........................................................44

12. Concentrations of cations, anions, dissolved inorganic carbon, and methane in ground water from monitoring wells at the Charleston, S.C., site, June 24-25, 1998 


\section{CONVERSION FACTORS}

$\begin{array}{rll}\text { Mulitply } & \text { By } & \text { To obtain } \\ \text { inch (in.) } & 25.4 & \text { millimeter } \\ \text { inch per year (in/yr) } & 25.4 & \text { millimeter per year } \\ \text { foot }(\mathrm{ft}) & 0.3048 & \text { meter } \\ \text { mile }(\mathrm{mi}) & 1.609 & \text { kilometer } \\ \text { square feet }\left(\mathrm{ft}^{2}\right) & 0.09294 & \text { meter squared } \\ \text { foot per day }(\mathrm{ft} / \mathrm{d}) & 0.3048 & \text { meter per day } \\ \text { foot per year }(\mathrm{ft} / \mathrm{yr}) & 0.3048 & \text { meter per year } \\ \text { gallon }(\mathrm{gal}) & 3.785 & \text { liter } \\ \text { gallon per day per foot }(\mathrm{gal} / \mathrm{d} / \mathrm{ft}) & 3.785 & \text { liter per day per foot } \\ \text { gallon per minute }(\mathrm{gal} / \mathrm{min}) & 3.785 & \text { liter per minute } \\ \text { foot squared per day }\left(\mathrm{ft}{ }^{2} / \mathrm{d}\right) & 0.09290 & \text { meter squared per day }\end{array}$

Temperature: In this report, temperature is given in degrees Celsius $\left({ }^{\circ} \mathrm{C}\right)$, which can be converted to degrees Fahrenheit $\left({ }^{\circ} \mathrm{F}\right)$ by the following equation: ${ }^{\circ} \mathrm{F}=\left(9 / 5 \times{ }^{\circ} \mathrm{C}\right)+32$

Sea level: In this report, "sea level" refers to the National Geodetic Vertical Datum of 1929-A geodetic datum derived from a general adjustment of the first-order level nets of the United States and Canada, formerly called Sea Level Datum of 1929.

Chemical concentration: In this report, chemical concentrations in water are expressed as micrograms per liter $(\mu \mathrm{g} / \mathrm{L})$; chemical concentrations in soil are expressed as micrograms per kilogram $(\mu \mathrm{g} / \mathrm{kg}$ - dry weight).

\section{ABBREVIATIONS and ACRONYMS}

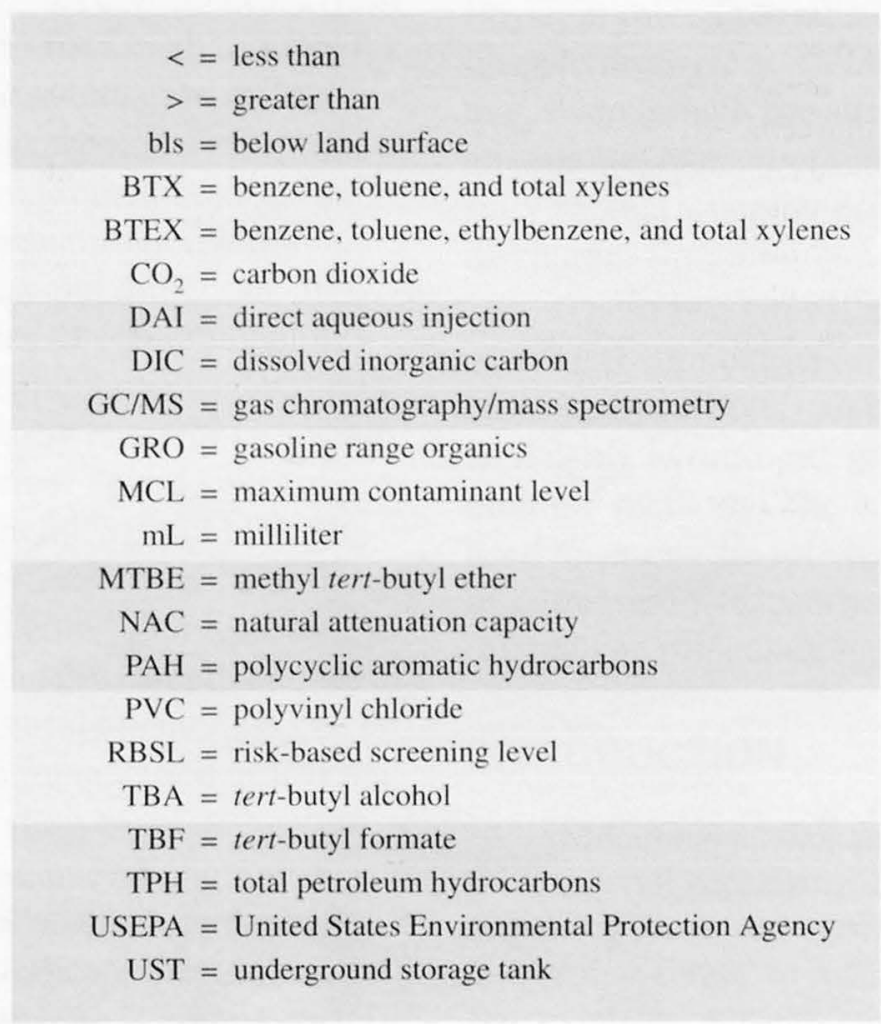




\title{
Methodology for Applying Monitored Natural Attenuation to Petroleum Hydrocarbon-Contaminated Ground-Water Systems with Examples from South Carolina
}

\author{
By Francis H. Chapelle, John F. Robertson, James E. Landmeyer, and Paul M. Bradley
}

\section{Abstract}

Natural attenuation processes such as dispersion, advection, and biodegradation serve to decrease concentrations of dissolved contaminants as they are transported in all ground-water systems. However, the efficiency of these natural attenuation processes and the degree to which they help attain remediation goals, varies considerably from site to site. This report provides a methodology for quantifying various natural attenuation mechanisms. This methodology incorporates information on (1) concentrations of contaminants in space and/or time; (2) ambient reduction/oxidation (redox) conditions; (3) rates and directions of ground-water flow; (4) rates of contaminant biodegradation; and (5) demographic considerations, such as the presence of nearby receptor exposure points or property boundaries. This document outlines the hydrologic, geochemical, and biologic data needed to assess the efficiency of natural attenuation, provides a screening tool for making preliminary assessments, and provides examples of how to determine when natural attenuation can be a useful component of site remediation at leaking underground storage tank sites.

At a site in the Piedmont Physiographic Province (Laurens, South Carolina), hydrologic and water-chemistry data indicate that the natural attenuation capacity for benzene is approximately
5 percent per foot of flowpath. As a result, benzene concentrations would decrease from about 28,000 micrograms per liter in ground water at the source area to less than 5 micrograms per liter 200 feet downgradient and prior to discharging to a stream. Because of this rapid attenuation, contaminants do not presently impact the stream downgradient of the site. In contrast, at a site in the Coastal Plain Physiographic Province (Charleston, South Carolina), hydrologic and water-chemistry data indicate that, even though the site has a substantial natural attenuation capacity, it may not be sufficient to fully protect a nearby point of ground-water discharge.

These two sites illustrate how the efficiency of natural attenuation processes acting on petroleum hydrocarbons can be systematically evaluated using hydrologic, geochemical, and microbiologic methods. These methods, in turn, can be used to assess the role that the natural attenuation of petroleum hydrocarbons can play in achieving overall site remediation.

\section{INTRODUCTION}

Monitored natural attenuation is a method of using naturally occurring, contaminant-degrading and dispersing processes, in combination with environmental monitoring, to remediate contaminated groundwater systems. All anthropogenic chemicals, including 
petroleum hydrocarbons, chlorinated solvents, metals, and radionuclides, are subject to natural attenuation processes. However, the effectiveness of these processes varies widely for different contaminants and among different ground-water systems. These differences are important because of the variety of hydrologic conditions that occur in shallow ground-water systems. The purpose of this report is to provide a methodology for assessing the natural attenuation of petroleum hydrocarbons, a major class of contaminants that have been released to the environment. This methodology is designed to be consistent with existing technical knowledge and regulatory guidance concerning monitored natural attenuation, and is adapted to the hydrologic and geochemical conditions characteristic of South Carolina.

The efficiency of natural attenuation processesdispersion, biodegradation, dilution, volatilization, and adsorption - vary from site to site. This variability, however, is not random and depends on the hydrologic, geochemical, and biologic characteristics of particular ground-water systems. Because these characteristics can be measured, and because these measurements can be interpreted in a logically consistent way, the efficiency of natural attenuation can be accurately assessed and documented. This report identifies the principles governing the natural attenuation of petroleum hydrocarbons, and develops a system for applying these principles that is consistent with Federal and South Carolina regulatory guidance.

\section{PROCESSES THAT CONTRIBUTE TO THE NATURAL ATTENUATION OF PETROLEUM HYDROCARBONS}

\section{Biodegradation}

Biodegradation processes are an important component of the natural attenuation of petroleum hydrocarbons because biodegradation can transform toxic petroleum hydrocarbons to environmentally innocuous compounds such as carbon dioxide and water. However, because most petroleum products are a complex mixture of many hydrocarbons, and because different hydrocarbons are subject to widely varying biodegradation rates, these processes must be carefully assessed in applications of monitored natural attenuation.
The effects of biodegradation processes on the mobility of petroleum hydrocarbons released to ground-water systems, and particularly the role of these processes in degrading and attenuating contamination, have not always been appreciated. As recently as 1981, papers using quantitative modeling techniques for evaluating hydrocarbon mobility did not consider the effects of microbial processes on hydrocarbon attenuation (Yazicigil and Sendlein, 1981).

By 1985, microbiologists had gathered clear evidence that biodegradation of petroleum hydrocarbons occurred in both aerobic and anaerobic aquifer systems. However, the most telling evidence that such processes were important came from numerous field studies showing that petroleum hydrocarbons were selectively removed under a variety of conditions. A study in California (Hadley and Armstrong, 1991), surveyed 7,167 water-supply wells for evidence of chemical contamination. Because gasoline spills had occurred from thousands of leaking underground storage tanks during the previous 50 years, these researchers anticipated that petroleum hydrocarbon contamination, particularly benzene contamination, would be prevalent. To the surprise of the investigators, very little evidence of benzene contamination of ground water was found. After reviewing the possible processes that could remove benzene from ground water, including sorption and evaporation, they concluded that biodegradation processes were the most likely reason for the puzzling "absence" of benzene.

The realization that microbial processes were important in the fate and transport of petroleum hydrocarbons in ground-water systems led to a number of investigations during the late 1980 's. These studies form a basis for evaluating biodegradation as a natural attenuation process and as a possible strategy for remediating hydrocarbon contamination in ground-water systems.

\section{Aerobic Oxidation}

The ability of microorganisms to degrade petroleum hydrocarbons has been widely studied, and many of the biochemical pathways involved in degradation have been worked out in some detail. However, it is difficult to predict how complex natural systems, particularly inaccessible ground-water systems, will react to hydrocarbon contamination. The "shrinking" of plumes containing benzene, toluene, ethylbenzene, and xylene (BTEX) in shallow ground-water systems had been widely reported during the 1980's, often with little documenting evidence. However, Barker and 
others (1987) reported the results of an experiment in which about 476 gallons (gal) of ground water containing 2.4 milligrams per liter $(\mathrm{mg} / \mathrm{L})$ benzene, $1.8 \mathrm{mg} / \mathrm{L}$ toluene, $1.1 \mathrm{mg} / \mathrm{L}$ each of $\mathrm{p}$-xylene, m-xylene, and $\mathrm{o}$-xylene (BTX), and 1,280 $\mathrm{mg} / \mathrm{L}$ chloride were injected into a shallow aerobic aquifer. The chloride was added to act as a conservative tracer. The resulting plume was then monitored by a dense network of multilevel piezometers. Samples from the monitoring wells were collected each day for 3 days after injection and monthly for 4 months thereafter.

By day 53, the combined effects of advection and dispersion had moved the chloride tracer plume between 3 and 16 feet (ft) along the natural gradient prevailing in the aquifer, spreading the plume to about three times its initial size as it moved. The benzene component of the plume behaved similarly to chloride in the first 53 days, spreading as it moved downgradient. The toluene component, however, was actually smaller at day 53 than at the beginning of the experiment. By day 108, the toluene component of the plume had virtually disappeared; furthermore, the benzene component of the plume had shrunk noticeably relative to the chloride tracer. By vertically integrating concentrations of BTX in the plume, it was possible to calculate the mass of each compound present as a function of time. The mass of chloride, as expected, changed very little. The masses of each BTX compound, however, decreased rapidly. By 108 days, the mass of toluene and the xylene isomers had decreased to nearly zero. Although benzene was more resistant to degradation than the other compounds, the mass of remaining benzene was virtually zero by 400 days after injection.

This experiment differed from real petroleum hydrocarbon spills in several ways. First, the large mass of aliphatic and alicyclic hydrocarbons present in all fuels was not included in the experiment because of the mass's lack of aqueous solubility. Thus, any effects of these compounds on BTX degradation were absent from the experiment. However, as great quantities of aliphatic compounds are not transported downgradient of petroleum spills, the experiment accurately simulated conditions downgradient of petroleum spills. In part, because of the lack of aliphatic hydrocarbons in the experiment, aerobic conditions prevailed in the aquifer throughout the experiment. Because aerobic bacteria may be more efficient hydrocarbon utilizers than anaerobic bacteria, this experiment probably recorded degradation rates as high as any that would be observed in ground-water systems.
The chief value of the experiment reported by Barker and others (1987) is that it verified numerous observations that BTX compounds were actively biodegraded in ground-water systems. However, because of the aerobic conditions and the lack of an immiscible hydrocarbon phase capable of leaching BTX compounds over time, the time required for complete degradation in this experiment was probably less than that required in most petroleum product spills.

\section{Anaerobic Oxidation}

One of the first consequences of petroleumhydrocarbon contamination of shallow ground-water systems is the development of anaerobic conditions near the plume. One well-documented example of this was a crude oil spill that occurred near Bemidji, Minn., in August 1979. Prior to the spill, the aquifer was aerobic (dissolved oxygen $\sim 10 \mathrm{mg} / \mathrm{L}$ ). Soon after the spill, however, increased levels of microbial respiration created anaerobic conditions near the oil lens. This, in turn, provided an opportunity for studying the anaerobic degradation of petroleum hydrocarbons in an anaerobic ground-water system under field conditions (Baedecker and others, 1988; 1993). Concentrations of all the BTEX compounds were observed to decrease substantially. In fact, all of the alkylbenzene compounds were observed to decrease. Because of the proximity to the oil lens, these concentration decreases could not be attributed to hydrodynamic processes, but rather were interpreted as reflecting anaerobic microbial degradation (Cozzarelli and others, 1988).

Further evidence that microbial processes are involved with degradation was provided by the observed distribution of organic acids in the anaerobic plume. Near the oil lens, fairly high concentrations of organic acids, particularly acetic acid, were observed. These acids have been shown to be intermediate products of anaerobic benzene and toluene degradation in laboratory experiments, and their presence is evidence that anaerobic microbial processes were actively degrading the hydrocarbons in this field situation. Downgradient of the oil lens, concentrations of the organic acids decreased because of consumption by a combination of methanogenesis (Baedecker and others, 1988) and Fe(III) reduction (Lovley and others, 1989). 


\section{Biodegradation of Methyl Tert-Butyl Ether}

Methyl tert-butyl ether (MTBE) was introduced in the 1970's as an octane replacement for tetraethyl lead. Since that time, MTBE has been employed as a fuel oxygenate to lower carbon monoxide emissions in accordance with the Clean Air Acts Amendments of 1990. MTBE is currently added to 30 percent of the gasoline consumed in the United States (Squillace and others, 1997). Because MTBE is highly soluble in water, is readily transported in ground- and surfacewater systems, has a low taste and odor threshold, and is tentatively classified by the U.S. Environmental Protection Agency (USEPA) as a possible human carcinogen, the potential contamination of drinkingwater supplies with MTBE has rapidly become a national concern. This concern has prompted the USEPA to establish a drinking-water advisory of 20 to 40 micrograms per liter $(\mu \mathrm{g} / \mathrm{L})$ for MTBE.

Because approximately 60 percent of the drinking water consumed in the continental United States comes from surface-water systems, the potential contamination of these systems with MTBE and tert-butyl alcohol (TBA) is particularly problematic. Although contamination of surface-water sources with fuel oxygenates can result from atmospheric deposition, stormwater runoff, and releases directly to surfacewater systems by industrial and recreational activities, the dissolved concentrations of MTBE associated with these processes are reported to be quite low (less than $10 \mu \mathrm{g} / \mathrm{L})$. In contrast, leakage from underground gasoline storage tanks and subsequent discharge of contaminated ground water can deliver high concentrations of fuel oxygenates to local surface-water systems. At a gasoline-spill site in Beaufort, S.C., for example, contaminated ground water containing $10,000 \mu \mathrm{g} / \mathrm{L}$ dissolved MTBE was transported to a nearby stream (Landmeyer and others, 1998). However, ground water discharging to a surface-water body must pass through bed sediments containing highly active microbial communities, which are capable of efficient degradation of otherwise recalcitrant compounds (Bradley and Chapelle, 1997). Thus, the potential exists for bed-sediment microbial communities to degrade MTBE and substantially diminish the effect of these contaminants on surface-water quality.

\section{Sorption Processes}

Sorption refers to the distribution of a solute between the aqueous phase and the solid phase. The solute may be adsorbed onto the surfaces of the solid matrix or absorbed into the interior of the sorbent matrix. Sorption, therefore, can act to remove solute from solution (adsorption) or add solute to solution (desorption). These combined adsorption-desorption processes are called "reversible sorption" and can have important effects on the transport of solutes in groundwater systems.

When a plume first develops from a new contaminant source, the sorptive capacity of the aquifer sediments is largely unfilled. As solutes migrate away from the source, they tend to adhere to aquifer sediments, and gradually saturate the sorptive capacity of the aquifer material. This initially retards the transport of contaminants relative to the velocity of ground water. In time, the sorptive capacity of the sediments becomes saturated, and the effects of retardation becomes less and less. The principal effect of sorption on the development of plumes is to retard the spread of contaminants rather than stop it. The steady-state configuration of plumes (that is, their extent when contaminant delivery from the source is balanced by the sum of the natural attenuation mechanisms) is independent of the sorption capacity of the aquifer. However, low-sorptive capacity aquifers will reach the steady-state configuration sooner than high-sorptive capacity aquifers.

Desorption, the processes by which solutes are released from contaminated aquifer sediments, is an important factor in any remediation effort. Aquifer sediments that contain large amounts of contaminant mass in the adsorbed phase, can continue to act as sources of contaminants for long periods of time. Desorption over time contributes to the contaminant "rebound" effect commonly observed in pump-andtreat remediation systems once the pumps are turned off, and can greatly increase the time needed to effect site cleanup. As a general rule, plumes develop rapidly in low-sorption capacity aquifers, and can be remediated rapidly as well. Conversely, in high-sorption capacity aquifers, plumes develop more slowly and take longer to remediate. For these reasons, remediation strategies should always include a quantitative evaluation of aquifer sorption capacity. 


\section{Advection and Dispersion}

Advection refers to the migration of solutes resulting from the movement of the fluid phase in which the solutes are dissolved. In sandy aquifers with relatively high horizontal hydraulic conductivity ( $K>10$ feet per day (ft/d)), advection is the dominant transport mechanism for relatively soluble contaminants such as chlorinated ethenes. If subsurface sediments were homogeneous, consideration of advective transport alone would account for much of the transport behavior of subsurface contaminants. However, the lithology, and thus the hydraulic conductivity, of ground-water systems are highly heterogeneous. Because of this heterogeneity, solutes advectively transported are subject to variations in transport speed. If it were possible to account for these variations, then advection alone could be used to describe solute transport. However, because these variations in advective transport are so complex, it is not practical to account for them in a meaningful way.

The traditional method for incorporating unknowns associated with advective transport is by "hydrodynamic dispersion." Dispersion is a process that causes a solute to occupy a larger volume of porous media than would be expected by advection alone. In part, dispersion accounts for the tendency of solutes to diffuse along concentration gradients, thus increasing the volume of the plume. But, dispersion is also a mathematical way of accounting for the uncertainty associated with hydraulic conductivity found in all ground-water systems. The most widely used form of the coefficient of hydrodynamic dispersion is:

$$
D=D_{0} \tau+\alpha v,
$$

where $D_{0}$ is the diffusion coefficient $\left(L^{2} T^{-1}\right)$ for the solute in question, $\tau$ is a dimensionless tortuosity factor, $\alpha$ is the dispersivity of the porous media $(L)$, and $v$ is pore-water velocity $\left(L T^{-1}\right)$. Under conditions where ground-water flow is substantial, the first term of equation 1 is negligible compared to the second term, and the equation reduces to:

$$
D=\alpha \nu \text {. }
$$

Thus, the "advective mixing," or dispersion, of a solute is proportional to how fast ground water is flowing $(v)$ and the ability of the aquifer material to "mix" the water $(\alpha)$. In reality, dispersivity is simply a representation of uncertainty in the hydraulic conductivity of aquifers - and, thus, uncertainty in the ground-water velocity field, which contributes to solute transport. Because this uncertainty is additive with distance along a given flowpath, dispersivity also increases as the plume grows. This scale-dependent behavior is a characteristic feature of dispersivity (Gelhar and others, 1992).

\section{Volatilization}

When petroleum hydrocarbons are spilled onto soil, they tend to migrate downward under the force of gravity until reaching the water table. Gasoline and other fuels are lighter than water and tend to spread, forming a lens of free-phase hydrocarbon liquid floating on the water table. Above this lens, gases in the unsaturated zone tend to be at or near saturation with the more volatile components present in the hydrocarbon. This is sometimes referred to as the zone where the air is at "residual saturation" with respect to the hydrocarbon. The diffusive transport of volatile hydrocarbons upward from the zone of residual saturation is one component of natural attenuation.

In addition to volatilization, the unsaturated zone is conducive to microbial growth. The volatile components of hydrocarbons, short-chained alkanes, cyclic alkanes, and aromatic components are readily oxidized by many kinds of soil bacteria. The presence of air allows oxygen to diffuse into the system with the consequent potential for aerobic metabolism. Thus, in addition to volatilization losses, there are substantial losses of hydrocarbons due to biodegradation in the unsaturated zone.

\section{Summing the Processes Contributing to Natural Attenuation}

Many factors affect the natural attenuation of solutes in ground-water systems, as previously discussed. These include hydrodynamic dispersion, advection, sorption, volatilization and biodegradation. In ground-water plumes, where volatilization losses are negligible, these processes can be summed mathematically to give overall concentration changes of a solute $C$ with time $(\partial C / \partial t)$. In this treatment, volatilization losses from the ground-water plume are considered negligible. In this case, $\partial C / \partial t$ is equal to the sum of hydrodynamic dispersion,

$D \frac{\partial^{2} C}{\partial x^{2}}$, advection $-v \frac{\partial C}{\partial x}$, sorption $-\frac{\rho_{b} K_{d}}{n} \frac{\partial C}{\partial x}$, and 
biodegradation $-k C$, to give the governing equation for solute transport as:

$$
\frac{\partial C}{\partial t}=D \frac{\partial^{2} C}{\partial x^{2}}-v \frac{\partial C}{\partial x}-\frac{\rho_{b} K}{n} \frac{\partial C}{\partial x}-k C,
$$

where $D$ is the coefficient of hydrodynamic dispersion (in feet squared per day), $v$ is the velocity of groundwater flow (in feet per day), $\rho_{b}$ is bulk density, $K_{d}$ is a linear sorption distribution coefficient, $n$ is porosity, and $k$ is a first-order biodegradation rate constant $\left(\right.$ days $\left.^{-1}\right)$ (Freeze and Cherry, 1979). The coefficient of hydrodynamic dispersion, in turn, is proportional to ground-water velocity and scale-dependent aquifer dispersivity $\alpha(\mathrm{ft})$.

In the equation 3 formulation, sorption is assumed to be adequately described by equilibrium between the adsorbed and aqueous phases $\left(K_{d}\right)$. The kinetics of biodegradation are assumed to be first order, which is a reasonable assumption if concentrations of contaminants are low relative to the capacity of indigenous microorganisms to use them (Bekins and others, 1998). However, other formulations of the biodegradation term based on full Monod kinetics are possible if the first order assumption is not considered reasonable. This (or other) formulations make it possible to quantify the effects of natural attenuation processes in ground-water systems.

\section{Natural Attenuation Capacity}

The concept of "assimilative capacity" is well known in soil science (Charbeneau and Daniel, 1993) and surface-water hydrology (Chapra, 1996), and refers to the capacity of a system to absorb and/or transform pollutants. By analogy, a "natural attenuation capacity" (NAC) can be defined for ground-water systems as the ability to lower contaminant concentrations along aquifer flowpaths.

In surface-water systems, assimilative capacity depends upon hydrologic (streamflow, mixing, and hydrodynamic dispersion), and biologic (biological oxygen demand) factors, and is assessed using analytical or digital water-quality models. Similarly, the NAC of ground-water systems depends upon hydrologic (dispersion and advection) and biologic (biodegradation rates) factors that can also be assessed using quantitative models. As we have seen, the sum of dispersive, advective, sorptive, and biodegradative processes acting on a solute in a one-dimensional flow system is given by equation 3 .

Appropriate procedures for solving equation 3 depend on hydrologic characteristics of the groundwater system in question, and the specific problems being addressed. When a contaminant plume has reached approximate steady-state conditions (that is, the plume is not expanding or contracting with time and $\partial \mathrm{C} / \partial t=0$ ), the sorption term becomes small relative to the other three terms, and the solute-transport equation simplifies to the ordinary differential equation:

$$
D \frac{d^{2} C}{d x^{2}}-v \frac{d C}{d x}-k C=0
$$

For boundary conditions of $C=C_{0}$ at $x=0$, and $C=0$ as $x \rightarrow \infty$, equation 2 has the particular solution:

$$
C(x)=C_{o} \exp ^{\left[\frac{-v+\sqrt{v^{2} 4 D k}}{2 D}\right] x .} .
$$

Equation 5 indicates that the steady-state solute concentration decrease away from a constant source is dependent on hydrodynamic dispersion $(D)$, the biodegradation rate constant $(k)$, and ground-water velocity $(v)$. With this usage, a positive value of $k$ indicates contaminant loss. The slope of the solute concentration profile along a flowpath is proportional to the value of

$$
\left[\frac{-v+\sqrt{v^{2} 4 D k}}{2 D}\right]
$$

which has units of feet ${ }^{-1}$. This represents the capacity of an aquifer to lower contaminant concentrations as ground water moves downgradient, and can be referred to as the NAC of a ground-water system. Multiplying equation 6 by 100

$$
N A C=\left[\frac{-v+\sqrt{v^{2} 4 D k}}{2 D}\right] \times 100,
$$


expresses NAC in units of "percent of contaminant concentration decline per foot." In other words, if a system has a NAC of 1 percent per foot, contaminant concentrations will decrease, on average, 1 percent for each foot of an aquifer flowpath segment. NAC represents an average concentration decrease summed over an entire flowpath segment, and does not imply that a given concentration decrease will occur for each individual foot of aquifer flowpath.
This reasoning identifies two ways that the NAC of a ground-water system can be used to achieve site remediation. The first way is if the NAC is sufficient to achieve plume containment without additional remediation procedures. In this case, monitored natural attenuation may be an acceptable stand-alone remedial strategy. In many other cases, however, the NAC may not be sufficient as a stand-alone remediation strategy. In these cases, engineering methods (for example, excavation,
The concept of NAC, as defined in equation 7 , is useful because it illustrates those characteristics of a hydrologic system that affect the efficiency of natural attenuation. For example, if the biodegradation rate constant is small $\left(\sim 0.001\right.$ days $\left.^{-1}\right)$ relative to the ground-water velocity $(\sim 1 \mathrm{ft} / \mathrm{d})$ and aquifer dispersivity (10 ft), the NAC of the system will also be small $(0.0990$ percent per foot of flowpath). Because of this small NAC, contaminants will be transported relatively long distances downgradient of a source area (fig. 1A). Conversely, if the biodegradation rate constant is high $\left(0.01\right.$ days $\left.^{-1}\right)$ relative to ground-water velocity $(0.2 \mathrm{ft} / \mathrm{d})$ and aquifer dispersivity ( $1 \mathrm{ft}$ ), the NAC will be proportionally higher (4.77 percent per foot of flowpath) and the transport of contaminants will be more restricted (fig. 1A).

In addition to $\mathrm{NAC}$, the distance that contaminants are transported in a ground-water system depends on contaminant concentrations at the source area $\left(C_{\mathrm{o}}\right.$ in eq. 5). If contaminant concentrations at the source are relatively high, a longer groundwater flowpath will be required for a given NAC to reach a maximum concentration level (MCL) than if source-area concentrations are lower (fig. 1B).
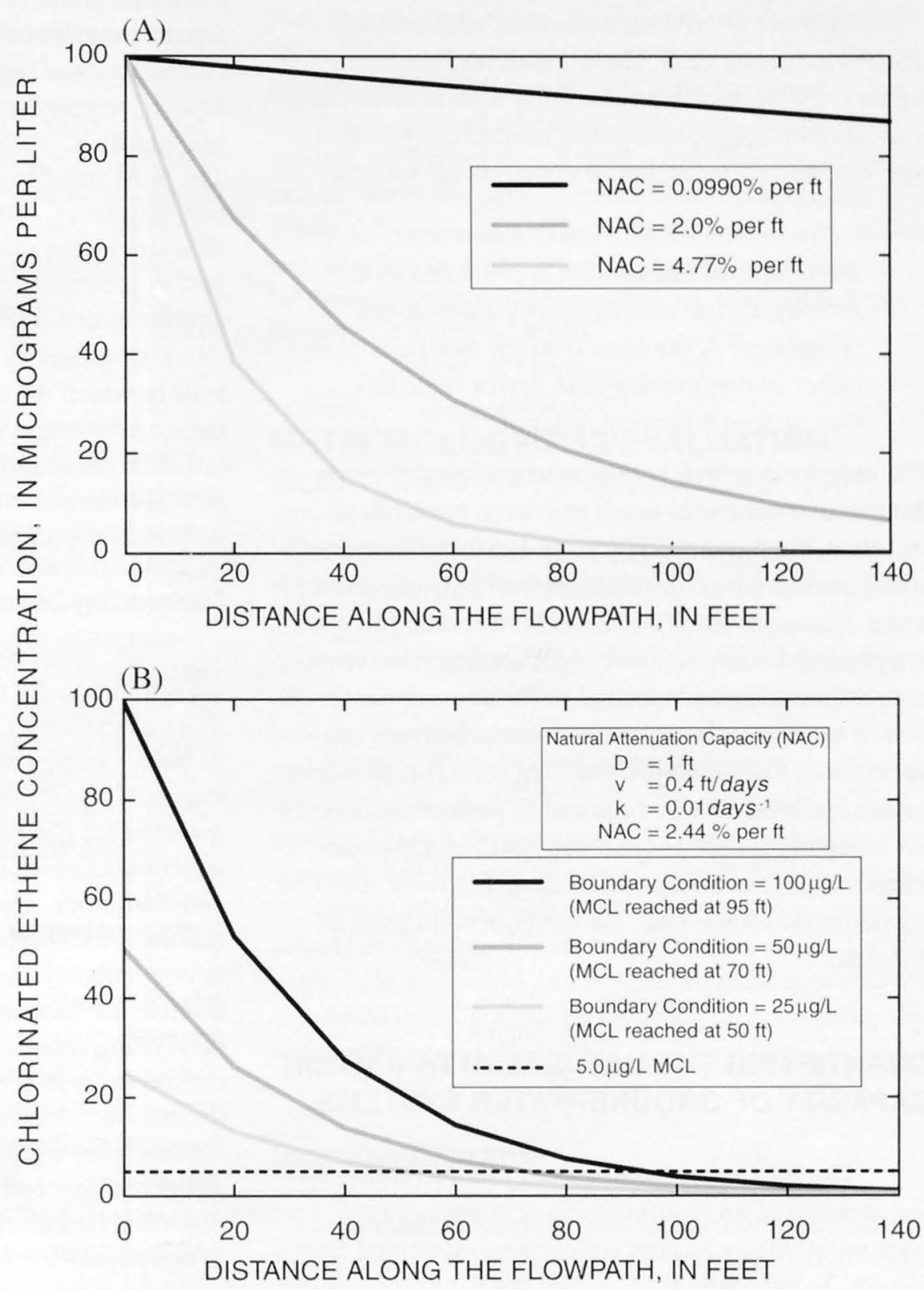

Figure 1. Effect of (A) natural attenuation capacity and (B) source-area concentrations on the distance required to decrease contaminant concentrations below maximum contaminant levels. 
in situ chemical oxidation, and in-situ bioremediation) must be used to lower source-area concentrations to levels that the NAC of an aquifer can continue to lower contaminant concentrations to MCL's in agreement with given points of compliance. Alternatively, the velocity of ground-water flow away from a contaminant-source area can be decreased using conventional pump-and-treat technology which, in turn, increases the NAC (fig. 1A).

This use of NAC is consistent with recent USEPA guidance (U.S. Environmental Protection Agency, 1999), which stresses that natural attenuation is most often appropriate when used in conjunction with engineered reduction of contaminant sources.

"In the majority of cases where moni-
tored natural attenuation is proposed as a
remedy, its use may be appropriate as one
component of the total remedy, that is,
either in conjunction with active remedia-
tion or as a follow-up measure."

The manner in which natural attenuation and active remediation measures (such as source removal, pumpand-treat, chemical oxidation, or enhanced bioremediation) are combined depends on the NAC of a groundwater system. If the NAC is small, for example, then active remediation measures will need to remove or immobilize a high proportion of the contaminant source to protect downgradient receptors from contamination. Conversely, if the NAC is large, then less source removal may be required to protect downgradient receptors. In either case, the NAC of a groundwater system must be quantified to effectively combine contaminant source-removal methods with natural attenuation.

\section{QUANTIFYING THE NATURAL ATTENUATION CAPACITY OF GROUND-WATER SYSTEMS}

The NAC of ground-water systems represents the capacity of an aquifer to lower contaminant concentrations as ground water moves downgradient (eq. 7). To calculate NAC, estimates for ground-water velocity $(v)$, the dispersion coefficient $(D)$, and the biodegradation rate constant $(k)$ are needed. Estimates for these parameters, in turn, can be obtained from site-specific hydrologic data.

\section{Estimating Ground-Water Velocity and Hydrodynamic Dispersion}

Estimates for ground-water velocities can be obtained from standard hydrologic techniques. The basic equation is Darcy's Law

$$
v=[d h / d x K] / n,
$$

where $v$ is velocity (in feet per day), $d h / d x$ is the hydraulic gradient (dimensionless) as determined from aquifer water-level measurements, $K$ is the hydraulic conductivity of the aquifer (in feet per day), and $n$ is aquifer porosity (dimensionless). Many methods exist to quantify $K$, including pumping tests and slug tests. The most suitable method is commonly dictated by site characteristics. Values for aquifer porosity can be measured from undisturbed sediment cores, but can just as accurately be estimated from the texture of the aquifer material (Freeze and Cherry, 1979).

Dispersivity can be directly measured by tracer tests in which the dispersion of a nonreactive solute is measured along a ground-water flowpath. In a compilation of measured dispersivity values from the literature, Gelhar and others (1992) showed that dispersivity increases in proportion to the length of the flowpath.

\section{Measuring Sorption Capacity}

The sorption of organic solutes on aquifer materials is traditionally measured using methods similar to those described by Schwartzenbach and Westall (1981). In brief, samples of approximately 5 grams of dried, sterilized aquifer material collected from the field site in question are placed in separate vials and amended with aqueous solutions of known petroleum-hydrocarbon concentrations. The vials are then equilibrated with the sediment for approximately 12 hours on a shaker table to continuously stir the solution. Samples of the liquid fraction are then analyzed for the petroleum hydrocarbons being considered. The amount of adsorbed compound is then estimated as the difference between the amount added and the amount present in the liquid fraction after equilibration with aquifer sediments. Adsorbed concentrations are then regressed against dissolved concentrations to obtain adsorption isotherms. When adsorption is linear, that is, concentrations of aqueous and adsorbed petroleum hydrocarbons can be fit to a line, adsorption can be described by the slope of the aqueous-adsorbed concentration plot. The slope of this straight line, $K_{d}$, is a semiquantitative indicator of the tendency of the compound to sorb. 


\section{Measuring Biodegradation Rates}

Microbial utilization of substrates (contaminants) conforms to enzyme saturation (Monod) kinetics according to the Michaelis-Menton equation

$$
V=\left[v_{\max } /\left(K_{s}+S\right)\right](S B),
$$

where $V$ is the rate of substrate uptake (moles of substrate per time per gram of cells), $v_{\max }$ is the maximum rate of substrate uptake, $K_{s}$ is the substrate concentration at which $v=1 / 2 v_{\max }, S$ is substrate concentration (moles per liter), and $B$ is the amount of cells (grams). At low substrate concentrations where $S \sim K$ (that is, substrate uptake is not limited by enzyme availability), and when the microbial population is neither increasing or decreasing with time, the Michaelis-Menton equation is approximated by first-order kinetics

$$
V \sim k S,
$$

where $k$ is a rate constant (units of $t^{-1}$ ). In many substrate-limited ground-water systems, first-order kinetics are an adequate approximation of contaminant degradation, and this approach has been widely used to simulate solute-transport of organic contaminants. This simplification, however, is not recognized as appropriate for sites with (1) high contaminant concentrations ( $>1 \mathrm{mg} / \mathrm{L})$ where the availability of degradation enzymes is substantially less than the availability of the contaminant (Bekins and others, 1998), (2) contaminant concentrations that are toxic to microorganisms,

(3) more than one substrate that limit microbial degradation rates, and (4) microbial populations that are increasing or decreasing.

One approach to measuring biodegradation rates is to collect aquifer material, construct static or flowthrough microcosms in the laboratory, and measure the decrease in concentrations of particular compounds, or the production of ${ }^{14} \mathrm{CO}_{2}$ from radio-labeled compounds (Chapelle and others, 1996). These methods are advantageous because they can be applied to a wide range of hydrologic systems and because abiotic controls can be used to separate biotic from abiotic effects. However, the laboratory approach introduces uncertainties due to sediment disturbance and difficulties in reproducing in situ conditions.

Two methods for estimating biodegradation rates from field data are a dispersion-model approach (Chapelle and others, 1996), and a conservative-tracer approach (Wiedemeier and others, 1996). Both methods were developed specifically for dissolved BTEX compounds.

Many studies have documented biodegradation rate constants for BTEX compounds in recent years. Compilations of this data (Wiedemeier and others, 1996) suggest that biodegradation rates of petroleum hydrocarbons are surprisingly similar in ground-water systems that otherwise have very different characteristics. In particular, if the oxic/anoxic nature of the aquifer is known, biodegradation rates for BTEX compounds and MTBE can be predicted fairly well. Oxic conditions prevail when concentrations of dissolved oxygen are higher than $2 \mathrm{mg} / \mathrm{L}$. Anoxic conditions prevail when dissolved oxygen concentrations are below $0.5 \mathrm{mg} / \mathrm{L}$. Mixed oxic/anoxic conditions, which are common in ground-water systems, are indicated by dissolved oxygen concentrations between 0.5 and $2 \mathrm{mg} / \mathrm{L}$.

\section{METHODOLOGY FOR EVALUATING MONITORED NATURAL ATTENUATION}

Preceding sections of this report have shown: (1) that petroleum hydrocarbons are acted on by a variety of natural attenuation processes in ground-water systems that include dispersion, sorption, and biodegradation; (2) that petroleum hydrocarbons are subject to both aerobic and anaerobic biodegradation processes, and that the efficiency of these biodegradation processes depends on the distribution of redox processes in the aquifer; (3) that these natural attenuation processes can be quantified in terms of a NAC, which depends on the interaction of dispersive and biodegradative processes; and (4) an example of how these concepts can be applied in the field was given. In this section, these concepts are combined into a general methodology for assessing monitored natural attenuation.

\section{Data Requirements}

A methodology for evaluating monitored natural attenuation, and the data requirements needed to make this assessment, are shown in figure 2. This methodology is designed to be generally applicable to all ground-water systems, and is intended to aid the decision-making process for using natural attenuation as a part of site remediation. 
1.

Deliniate Contaminant Source Areas

Characterize contaminant source area(s) including

1. Presence/absence of NAPL (Non-Aqueous Phase Liquid).

2. Area/volume of contaminated aquifer sediments.

3. Concentration/mass of contaminants
2.

Define Contaminant

\section{Plume}

Characterize extent and concentrations

of contaminants emanating from source areas.

\section{3.}

\section{Aquifer Characteristics}

Measure hydrologic characteristics needed to determine rates and directions of ground-water flow including:

1. Aquifer hydraulic conductivity

2. Aquifer porosity

3. Hydraulic gradients

\section{4.}

Dispersive Characteristics

Estimate aquifer dispersivity from scale of the plume

5.

Sorptive Characteristics

Measure sorptive capacity of aquifer sediments

7.

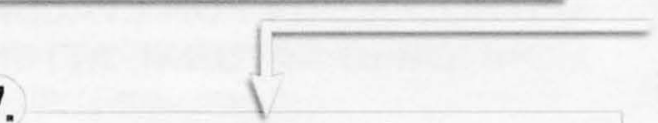

6.

Redox Characteristics

Measure redox-sensitive water-chemistry

characteristics to determine distribution

of TEAPS (Terminal Electon Accepting Process) in the aquifer.

\section{Biodegradation Processes}

Determine the presence of reductive, oxidative, or

cometabolic biodegradation processes.

9.

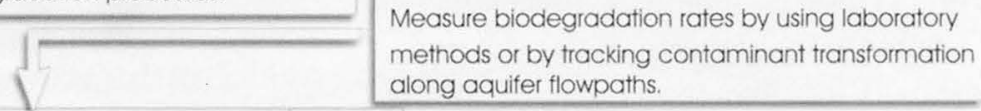

\section{Evaluate Natural Attenuation} Capacity (NAC)

10.

Given aquifer dispersion (D), ground-water velocity (v), and biodegradation rate $(\mathrm{k})$, calculate natural attenuation capacity from the relation:

$$
N A C=\left[\frac{-v+\sqrt{v^{2}+4 D k}}{2 D}\right] \times 100
$$
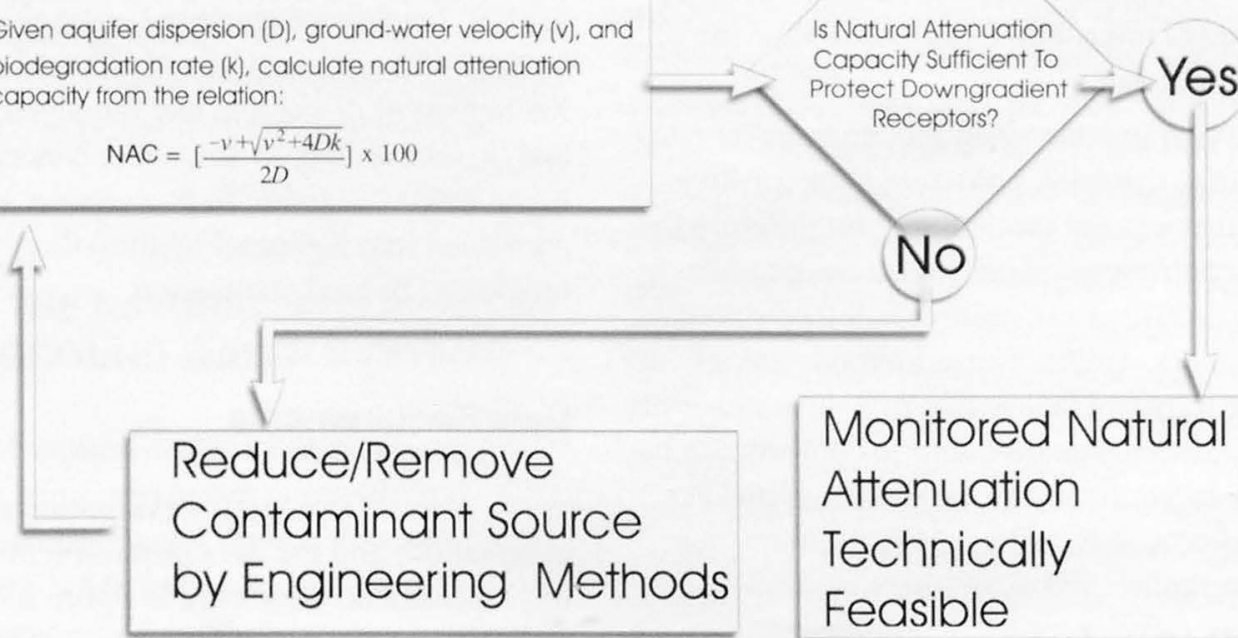

Figure 2. Methodology for evaluating monitored natural attenuation. 
Methodology includes the following steps:

1. Delineate the source area. Without knowing the location of contaminated aquifer sediments in the source area (that is, the part of the aquifer originally contaminated by petroleum hydrocarbons), without knowing the approximate area or volume of contaminated aquifer sediment, and without knowing aqueous concentrations of a contaminant at the source areas, evaluation of monitored natural attenuation is not technically feasible.

2. Define the areal and vertical extent of the contaminant plume emanating from the source areas. Documenting contaminant concentration changes within the plume is especially important, as well as documenting the presence or absence of chlorinated ethene transformations occurring in the plume. Most of the uncertainty associated with estimating degradation kinetics comes directly from uncertainties associated with contaminant concentration changes in the plume.

3. Quantify hydrologic characteristics of the aquifer including the areal and vertical distribution of hydraulic conductivity and porosity. In addition, prepare potentiometric maps to indicate directions of ground-water flow and hydraulic gradients. Use Darcy's Law (eq. 8) to estimate the range of ground-water flow rates at the site.

4. Estimate aquifer dispersivity from the scale of the plume and from the heterogeneity of aquifer hydraulic conductivity.

5. Estimate sorptive characteristics of aquifer sediments using laboratory partition measurements.

6. Characterize the oxic/anoxic nature of the system.

7. Estimate biodegradation rates for individual petroleum hydrocarbons in the plume of environmental concern, such as benzene or MTBE, using either a dispersion model approach or a conservativetracer approach. Laboratory estimates of biodegradation rates are meaningful only if the redox conditions present in the field are adequately duplicated in laboratory microcosms.

8. Estimate the NAC of the aquifer (eq. 7), which gives NAC in units of percent contamination loss per foot of flowpath, and where $v$ is ground-water velocity, $D$ is the coefficient of hydrodynamic dispersion, and $k$ is a first-order biodegradation rate constant. As a general rule, a NAC between 0.005 and 1.0 percent per foot of flowpath indicates relatively inefficient natural attenuation (fig. 3).

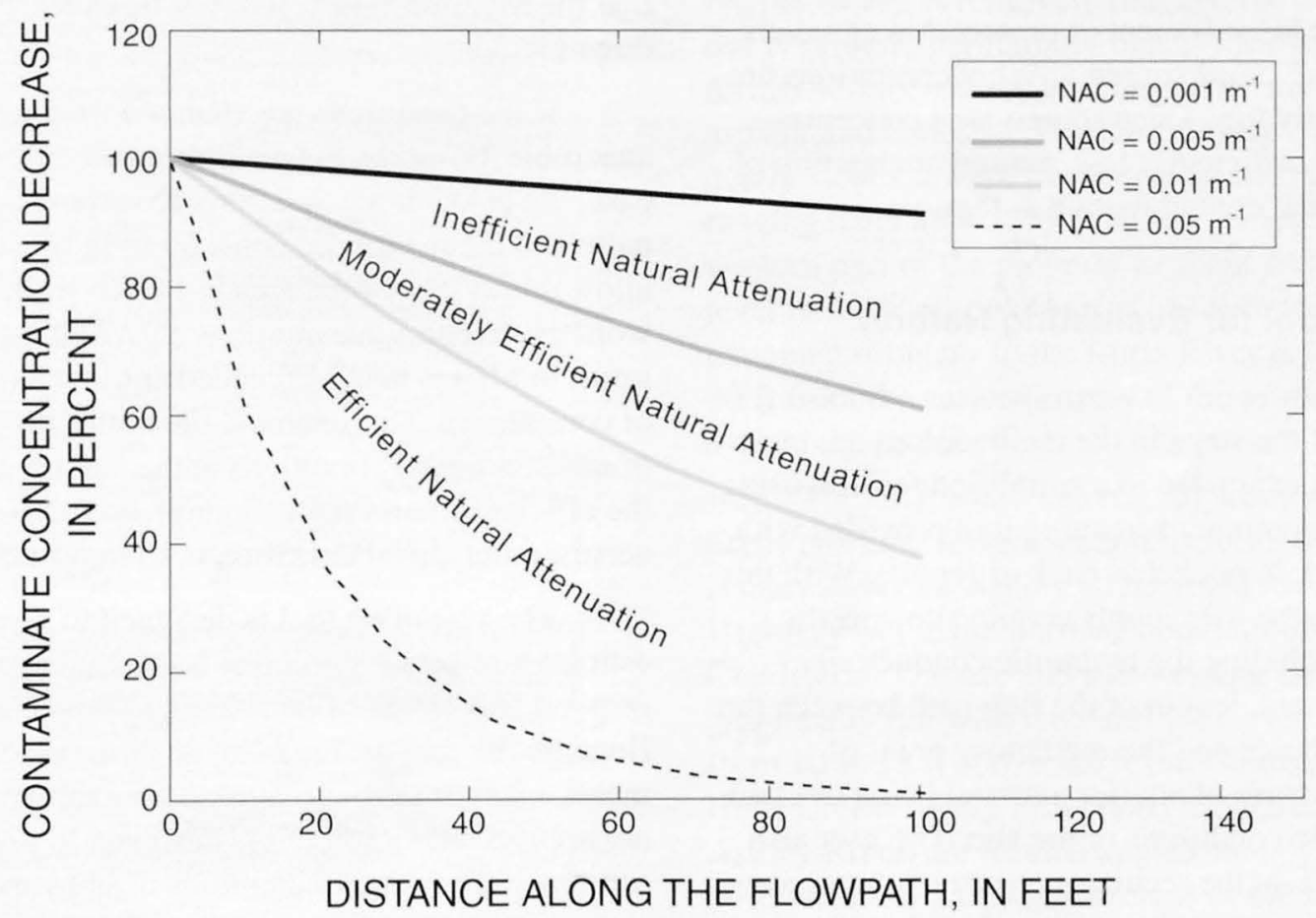

Figure 3. Effect of natural attenuation capacity (NAC) on contaminant concentration declines with increasing distance along a flowpath. NAC less than $0.005 \mathrm{ft}^{-1}$ indicates inefficient natural attenuation, NAC between 0.01 and $0.005 \mathrm{ft}^{-1}$ indicates moderately efficient natural attenuation, and NAC between 0.05 and $0.01 \mathrm{ft}^{-1}$ indicates efficient natural attenuation. 
Conversely, a NAC of more than 1.0 percent per foot of flowpath indicates relatively efficient natural attenuation (fig. 3).

9. In this step, a decision is made. If the NAC of a system is sufficient to lower plume concentrations to specified levels (usually MCL's) at specified locations in an aquifer (usually a sensitive receptor or a property boundary), monitored natural attenuation is an appropriate stand-alone remedial strategy. However, if source-area concentrations are too high for the NAC to lower contaminant concentrations sufficiently, engineered source-area remediation will be required. Source-area remediation can involve contaminant removal (excavation), in situ oxidation, in situ reduction, and/or pump-and-treat technology. In this case, the goals for source-area remediation can be identified by the NAC of the system. If NAC is low, contaminant concentrations in the source areas may need to be lowered substantially to reach remediation goals. Conversely, if the NAC is high, contaminant concentrations in the source area will need to be lowered less to reach remediation goals. In either case, the flowchart continues to cycle back to the question: "Is the NAC sufficient to protect downgradient receptors?" until source-area concentrations are sufficiently low. Once source-area concentrations are sufficiently low, natural attenuation of the residual contamination is feasible.

\section{Screening Tool for Evaluating Natural Attenuation}

Many of the steps in the methodology given in figure 2 can be evaluated in a simplified fashion using an interactive computer screening tool provided with this report (disk in pocket at back of report). With this screening tool, the user inputs certain site-specific information including the hydraulic conductivity, hydraulic gradient, length of the flowpath between the contaminant source and the regulatory point of compliance, texture of aquifer material (sand or clay), and oxic/anoxic conditions of the site. The user also assigns an MCL at the regulatory point of compliance. The tool then assigns a dispersivity based on the length of the specified flowpath, a porosity based on aquifer material texture, and biodegradation rates based on the particular hydrocarbon under consideration and the ambient oxic/anoxic conditions.
The screening tool then calculates ground-water velocity and the NAC of the aquifer in units of percent per foot of flowpath. Finally, the tool calculates the contaminant concentration in the source area that will degrade below the MCL at the specified regulatory point of compliance using equation 5 .

For example, if the hydraulic conductivity $(K)$ equals $1 \mathrm{ft} / \mathrm{d}$, the length of the flowpath equals $100 \mathrm{ft}$, the hydraulic gradient equals 0.01 , and an MCL of $5 \mu \mathrm{g} / \mathrm{L}$ are entered-and if aerobic conditions are specified, the contaminant of concern is specified as benzene, the aquifer material is specified as clay, and the "calculate" button is clicked - the tool will calculate a ground-water velocity of $0.0286 \mathrm{ft} / \mathrm{d}$, a NAC of 27.46 percent per foot of flowpath, and then indicate that a benzene concentration of $60,000 \mu \mathrm{g} / \mathrm{L}$ at the source area would degrade below the MCL of $5 \mu \mathrm{g} / \mathrm{L}$ at the point of compliance. The tool will not allow contaminant concentrations at the source to exceed the solubility limit of the particular hydrocarbon in gasoline, which is $60,000 \mu \mathrm{g} / \mathrm{L}$ for benzene. In this scenario, even if benzene concentrations at the source area are at the solubility limit of benzene, the NAC of this system is so high (27 percent per foot of flowpath) that the MCL of $5 \mu \mathrm{g} / \mathrm{L}$ will not be exceeded $100 \mathrm{ft}$ downgradient.

If the conditions are changed from aerobic to anaerobic, however, the result is much different. In this case, the NAC drops to 3.39 percent per foot of flowpath, and the maximum concentration of benzene allowable at the source area is $147.65 \mu \mathrm{g} / \mathrm{L}$. In other words, benzene concentrations above $147.65 \mu \mathrm{g} / \mathrm{L}$ will result in MCL's being exceeded at the regulatory point of compliance. This example illustrates the importance of environmental conditions at the site for assessing the efficiency natural attenuation, and shows why accurate site characterization is so important.

The screening tool is designed to give users estimates of how a particular hydrologic system will respond to releases of petroleum hydrocarbons. Because the tool makes many assumptions and estimates, using it as the sole basis for evaluating a site is not appropriate. Rather, it is designed to give overall estimates. The data assumptions used by the tool for assigning porosity are given in table 1; the assumptions used for dispersivity are given in table 2; biodegradation rates assumptions are given in table 3 ; and maximum contaminant concentrations, based on contaminant solubility, are given in table 4. 
Table 1. Porosities assigned to different textures of aquifer materials within the natural attenuation screening tool

\begin{tabular}{lc}
$\begin{array}{c}\text { Aquifer material } \\
\text { texture }\end{array}$ & $\begin{array}{c}\text { Assigned porosity } \\
\text { value }\end{array}$ \\
\hline Sand & 0.20 \\
Mixed sand and clay & .27 \\
Clay & .35 \\
\hline
\end{tabular}

Table 2. Dispersivities assigned to flowpaths of differing lengths within the natural attenuation screening tool

$[<$, less than; $>$, greater than $]$

\begin{tabular}{cc}
\hline $\begin{array}{c}\text { Length of flowpath } \\
\text { (feet) }\end{array}$ & $\begin{array}{c}\text { Assigned dispersivity } \\
\text { (feet) }\end{array}$ \\
$<100$ & 1 \\
$100-200$ & 2 \\
$200-300$ & 3 \\
$300-400$ & 4 \\
$400-500$ & 5 \\
$500-1,000$ & 10 \\
$>1,000$ & 20 \\
\hline
\end{tabular}

Table 3. Biodegradation-rate constants assigned for different redox conditions within the natural attenuation screening tool

[MTBE, methyl tert-butyl ether]

\begin{tabular}{lccc}
\hline \multirow{2}{*}{ Contaminant } & \multicolumn{3}{c}{ Biodegradation-rate constant $\left(\right.$ days $\left.^{-1}\right)$} \\
\cline { 2 - 4 } & $\begin{array}{c}\text { Fully } \\
\text { aerobic }\end{array}$ & $\begin{array}{c}\text { Aerobic/ } \\
\text { anaerobic }\end{array}$ & $\begin{array}{c}\text { Fully } \\
\text { anaerobic }\end{array}$ \\
\hline Benzene & 0.01 & 0.005 & 0.001 \\
MTBE & .006 & .001 & .003 \\
Toluene & .05 & .03 & .01 \\
Xylene & .008 & .005 & .005 \\
Naphthalene & .05 & .03 & .01 \\
\hline
\end{tabular}

Table 4. Maximum solubilities of contaminants allowed by the natural attenuation screening tool [MTBE, methyl tert-butyl ether]

\begin{tabular}{lc}
\hline Contaminant & $\begin{array}{c}\text { Maximum solubility limit } \\
\text { (micrograms } \\
\text { per liter) }\end{array}$ \\
\hline Benzene & 60,000 \\
MTBE & $5,000,000$ \\
Toluene & 20,000 \\
Xylene & 20,000 \\
Naphthalene & 20,000 \\
\hline
\end{tabular}

\section{APPLICATION OF NATURAL ATTENUATION METHODOLOGY TO TWO SITES IN SOUTH CAROLINA}

Two gasoline-spill sites, one each in Laurens and Charleston, S.C., were chosen to represent two of the most common environmental settings in the State. Differences in aquifer composition and characteristics can affect contaminant migration and attenuating factors. The Laurens site (fig. 4) is underlain by a saprolitic water-table aquifer typical to the Piedmont Physiographic Province, and accounts for about 63 percent of the State's land area. The Charleston site (fig. 5) is underlain by a sandy surficial aquifer typical of most areas in the Coastal Plain Physiographic Province of South Carolina, and accounts for about 35 percent of the State's land area.

The Laurens site (fig. 4), known as the former North Harper Street British Petroleum (BP) station, is located on U.S. Highway 221 (North Harper Street) just within the northeastern city limits of Laurens. The area surrounding the site is characteristic of Piedmont upland topography, consisting of rolling hills and ridges bisected by moderately steep stream valleys. The northwestern part of the site, adjacent to North Harper Street, is relatively flat, and the use of fill material is evident, particularly beneath the location of the former service-station building. This area is paved with asphalt and concrete. The land surface of the site gently slopes toward the southeast with elevations ranging from about $659 \mathrm{ft}$ above sea level in the northwestern part of the property to about $647 \mathrm{ft}$ above sea level in the southeastern part of the property. A small, unnamed tributary to the Little River is located about $30 \mathrm{ft}$ from the eastern corner of the property and flows toward the south.

The Charleston site (fig. 5), known as the former Oasis gasoline service station, is located west of the Ashley River on Ashley River Road (South Carolina Highway 61) in the northwestern part of the city of Charleston. The site and surrounding area is topographically flat with land-surface elevations ranging from 10 to $13 \mathrm{ft}$ above sea level. Church Creek and Bulls Creek, tidally influenced tributaries of the Ashley River, are located approximately $2,000 \mathrm{ft}$ northwest and 3,000 ft southeast of the site, respectively. The site is bounded on the southeast and southwest by drainage ditches that converge at the south corner of the property. Approximately 40 percent of the site's land area, specifically the northern corner of the property, is paved with asphalt. 


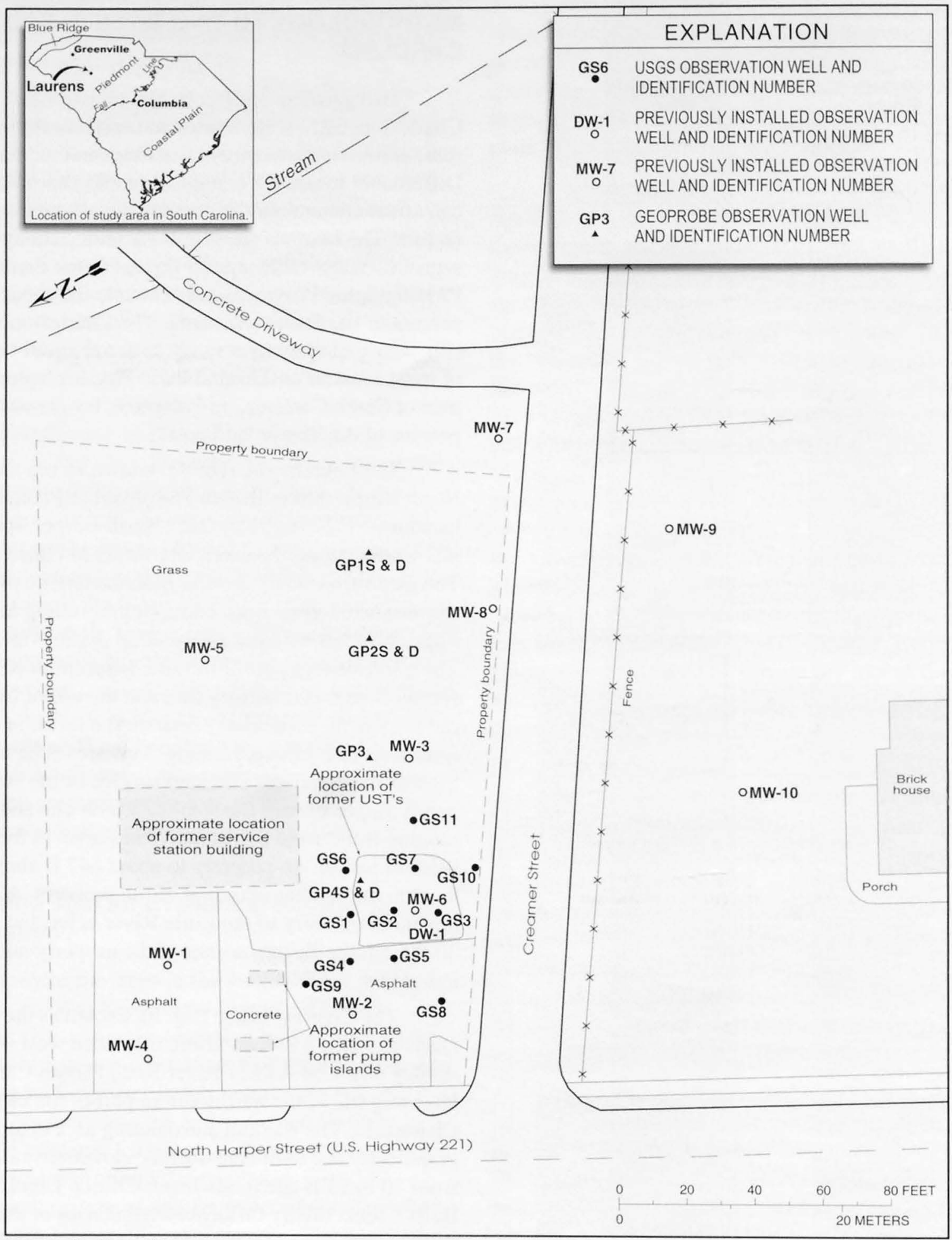

Base modified from Alpha

Environmental Sciences, Inc., 1997

Figure 4. Study area and location of wells and boreholes at the Laurens, S.C., site. 


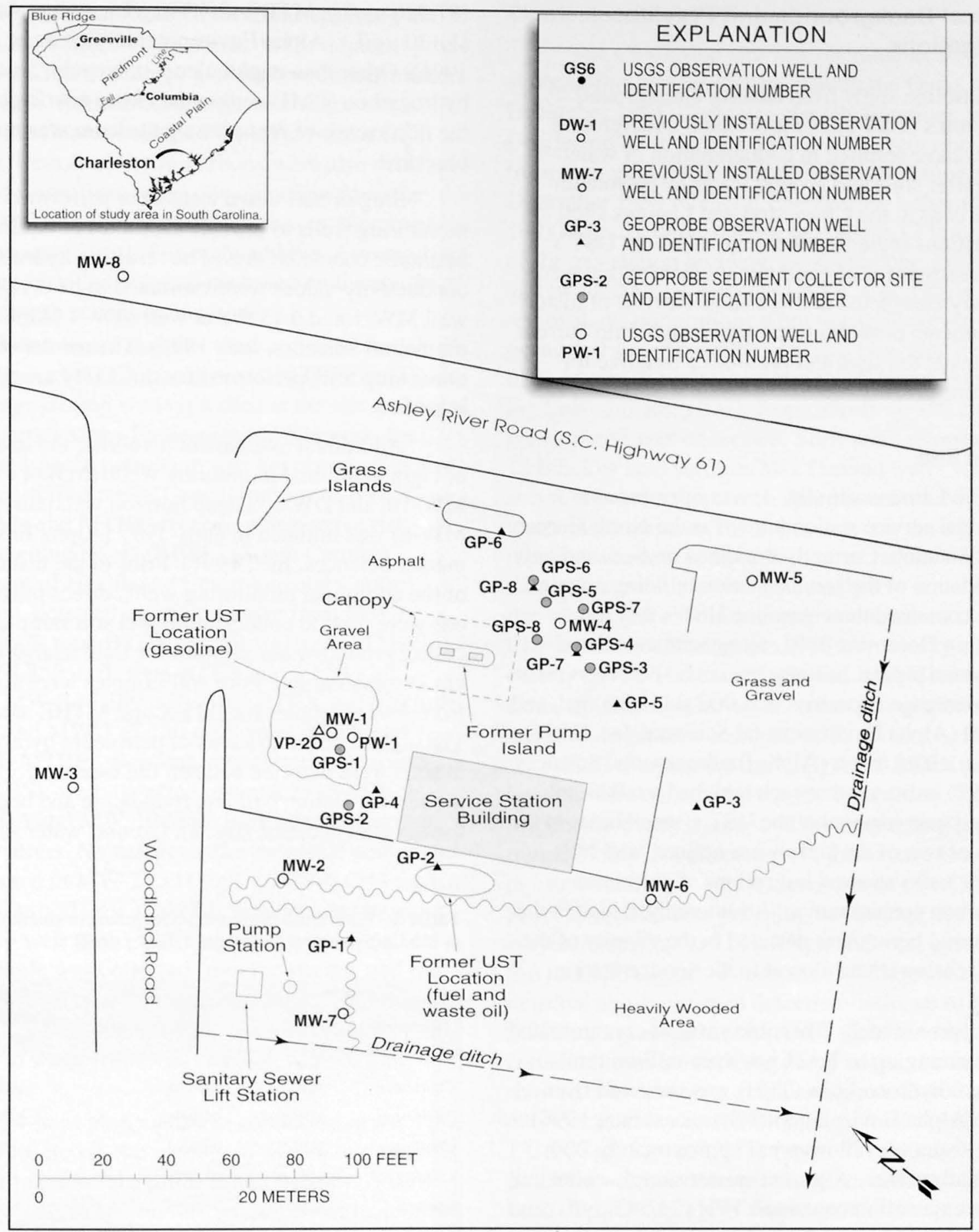

Base modified from General

Engineering Laboratories, 1993

Figure 5. Study area and location of wells and boreholes at the Charleston, S.C., site. 


\section{Historical Backgrounds and Previous Investigations}

Gasoline spills from leaking underground storage tanks (UST's) and associated underground pipelines have resulted in contamination of watertable-aquifer soils and ground water by petroleum hydrocarbons at the Charleston and Laurens sites. Investigations regarding the removal of the UST's and the assessment of contaminant distribution were previously completed at these sites. Review of historical documents provides important insight into current conditions at the sites and provides a baseline for subsequent investigation.

\section{Laurens Site}

The Laurens site (fig. 4) was operated as a commercial service station known as the North Harper Street BP station. Currently the site is unused, and only the foundation of the service-station building remains. The site contained three gasoline UST's that were removed in December 1991, along with associated underground piping. Initially, the tanks were reported to have had storage capacities of 4,000 gal, 2,000 gal, and 1,000 gal (Alpha Environmental Sciences, Inc., 1996). However, a later report (Alpha Environmental Sciences, Inc., 1997) indicated that each tank had a 6,000-gal capacity. Upon removal of the UST's, small holes in the bottoms of two of the tanks were noticed, and soils below the tanks showed indications of petroleumhydrocarbon contamination. Additionally, a leak in the underground piping was detected in the vicinity of the fuel-dispensing island closest to the service-station building.

Approximately 200 cubic yards of contaminated soil containing up to 1,324 parts per million total petroleum hydrocarbons (TPH) was removed from the site (Alpha Environmental Sciences, Inc., 1996). Ground-water elevations were approximately $22 \mathrm{ft}$ below land surface. A ground-water sample collected from the excavation contained TPH $(21,543 \mu \mathrm{g} / \mathrm{L})$ and total BTEX $(34,100 \mu \mathrm{g} / \mathrm{L})$ (Alpha Environmental Sciences, Inc., 1996).

Monitoring wells MW-1, MW-2, and MW-3 (fig. 4) were installed, and ground water from the wells was sampled (Alpha Environmental Sciences, Inc., 1996). Elevated concentrations of BTEX compounds, MTBE, and naphthalene were detected in water from all three wells. Water from well MW-2 contained the highest concentrations - total BTEX
$(87,920 \mu \mathrm{g} / \mathrm{L}), \operatorname{MTBE}(2,480 \mu \mathrm{g} / \mathrm{L})$, and naphthalene $(1,130 \mu \mathrm{g} / \mathrm{L})$ (Alpha Environmental Sciences, Inc., 1996). Other than naphthalene, polycyclic aromatic hydrocarbon (PAH) compounds were not detected, and the occurrence of free-phase petroleum was not observed.

Slug or bail-down tests were performed at two monitoring wells to provide estimates of aquifer hydraulic characteristics. The resulting hydraulic conductivity values were estimated to be $0.11 \mathrm{ft} / \mathrm{d}$ at well MW-1 and $0.15 \mathrm{ft} / \mathrm{d}$ at well MW-3 (Alpha Environmental Sciences, Inc., 1996). The results of additional slug tests performed for this study are tabulated in table 5 .

Additional assessment involving the installation of eight additional monitoring wells (MW-4 through MW-10, and DW-1, a deep horizon well paired with MW-6) was initiated in early 1997 (Alpha Environmental Sciences, Inc., 1997). Prior to the installation of the additional monitoring wells, direct-push methods were used to collect additional soil samples and to collect ground-water samples for field analysis using a gas chromatograph. Four soil samples were collected from four coreholes for BTEX and MTBE analysis. The highest concentrations of petroleum hydrocarbons in soils were detected beneath the western corner of the service-station building foundation and beneath the former UST location (fig. 4). Ground-water samples

Table 5. Estimated horizontal hydraulic conductivity values at the Laurens and Charleston, S.C., sites

\begin{tabular}{l|cccc|}
$\begin{array}{c}\text { Site } \\
\text { location }\end{array}$ & Well & $\begin{array}{c}\text { Test } \\
\text { date }\end{array}$ & $\begin{array}{c}\text { Test } \\
\text { No. }\end{array}$ & $\begin{array}{c}\text { Hydraulic } \\
\text { conductivity }(\boldsymbol{k}) \\
\text { (feet per day) }\end{array}$ \\
\hline Charleston & MW-2 & $9 / 09 / 98$ & 1 & 20 \\
Charleston & MW-3 & $9 / 09 / 98$ & 1 & 20 \\
Charleston & MW-5 & $9 / 09 / 98$ & 1 & 40 \\
Charleston & MW-6 & $9 / 09 / 98$ & 1 & 40 \\
Laurens & MW-1 & $5 / 22 / 98$ & 1 & 3 \\
Laurens & MW-2 & $5 / 20 / 98$ & 1 & 3 \\
Laurens & MW-3 & $5 / 22 / 98$ & 1 & .5 \\
Laurens & MW-3 & $9 / 17 / 98$ & 2 & .4 \\
Laurens & MW-5 & $5 / 22 / 98$ & 1 & 8 \\
Laurens & MW-5 & $5 / 22 / 98$ & 2 & 8 \\
Laurens & MW-7 & $5 / 20 / 98$ & 1 & 3 \\
Laurens & MW-7 & $9 / 17 / 98$ & 2 & 1 \\
Laurens & MW-8 & $5 / 20 / 98$ & 1 & 1 \\
Laurens & DW-1 & $5 / 20 / 98$ & 1 & 2
\end{tabular}


were collected from fourteen locations spanning the property, including five locations on the adjacent property across Creamer Street. The highest concentrations of petroleum hydrocarbons in ground water were detected in samples collected from the former UST locations. Petroleum hydrocarbons were also detected in ground water from areas downgradient from the former UST locations, as well as areas on the property across Creamer Street. The eight additional monitoring wells were installed at locations based on the results of the direct-push screening methods.

Ground-water samples were collected for laboratory analysis of BTEX compounds, MTBE, and PAHs from all monitoring wells installed at the site and adjacent property (Alpha Environmental Sciences, Inc., 1997). Free-phase petroleum was not observed in any of the monitoring wells. Concentrations of BTEX compounds and MTBE exceeding respective riskbased screening levels (RBSL) (South Carolina Department of Health and Environmental Control, $1995)$ were detected in ground water from MW-6 $(81,620 \mu \mathrm{g} / \mathrm{L}$ total BTEX and 59,500 $\mu \mathrm{g} / \mathrm{L}$ MTBE), MW-2 $(63,850 \mu \mathrm{g} / \mathrm{L}$ total BTEX and $4,650 \mu \mathrm{g} / \mathrm{L}$ MTBE), MW-3 (7,389 $\mu \mathrm{g} / \mathrm{L}$ total BTEX and $829 \mu \mathrm{g} / \mathrm{L}$ MTBE), and MW-1 (2,150 $\mu \mathrm{g} / \mathrm{L}$ total BTEX and $65.6 \mu \mathrm{g} / \mathrm{L}$ MTBE). Benzene concentrations exceeding the RBSL were detected in water from MW-9 $(5.79 \mu \mathrm{g} / \mathrm{L})$ and MW-10 $(95.6 \mu \mathrm{g} / \mathrm{L})$, located across Creamer Street. Naphthalene, the only PAH compound, was detected in MW-3 (331 $\mu \mathrm{g} / \mathrm{L}), \mathrm{MW}-6(544 \mu \mathrm{g} / \mathrm{L})$, and MW-2 $(630 \mu \mathrm{g} / \mathrm{L})$. MTBE was detected in water from deep well DW-1 (2.65 $\mu \mathrm{g} / \mathrm{L})$. A single surfacewater sample was collected from the stream, and the only petroleum hydrocarbon detected was MTBE $(1.31 \mu \mathrm{g} / \mathrm{L})$. Petroleum hydrocarbons were not detected in water from wells MW-4, MW-5, MW-7, and MW-8.

A 24-hour pump test was conducted in a temporary well located in the vicinity of MW-4 to provide estimates of surficial aquifer characteristics. A flow rate of 0.5 gallon per minute ( $\mathrm{gal} / \mathrm{min}$ ) was maintained throughout the test. Using various assumptions, such as a saturated aquifer thickness of $25 \mathrm{ft}$, a hydraulic gradient of 0.04 , and an aquifer material porosity of 30 percent, the following estimates were obtained: a transmissivity value of 57 gallons per day per foot ( $\mathrm{gal} / \mathrm{d} / \mathrm{ft}$ ); a storativity value of 0.23 ; a hydraulicconductivity value of $0.30 \mathrm{ft} / \mathrm{d}$; and a seepage velocity of 14.9 feet per year (ft/yr) (Alpha Environmental Sciences, Inc., 1997).

\section{Charleston Site}

The Charleston site was operated as a commercial gasoline service station, named the Oasis, until December 1991. Currently, the site functions as Charleston Auto Repair. Five UST's were removed from two areas at the former Oasis gas station in December 1991 (General Engineering Laboratories, 1991) (fig. 5). One area, located about $13 \mathrm{ft}$ northwest of the gas-station building, contained one 2,000-gal and two 8,000-gal gasoline UST's. Upon their removal, no perforations were noted; however, the excavated soils showed visual and olfactory indications of petroleum contamination (General Engineering Laboratories, 1991). Approximately 350 cubic yards of soil was excavated. Soils were removed to $12 \mathrm{ft}$ below land surface (bls). Ground water was found at $8 \mathrm{ft}$ bls, and a petroleum sheen was noticed on the water-table surface. The depth to water during tank removal was low compared to more recent water-level data collected at the site. Unusually low water levels due to drought conditions were documented in the Charleston area during late 1991 (Vroblesky and others, 1995). The excavation was backfilled with clean fill material; however, some contaminated soils were left in place.

Soil samples for the analysis of BTEX and TPH content were collected from the excavation, the dispensing-pump island, and the connecting piping trench. Samples collected from the excavation and the piping trench contained concentrations of toluene (up to 1,180 micrograms per kilogram $(\mu \mathrm{g} / \mathrm{kg}$, dry weight)) ethylbenzene (up to $214 \mu \mathrm{g} / \mathrm{kg}$ ), and total xylenes (up to $1,350 \mu \mathrm{g} / \mathrm{kg}$ ). Benzene and TPH were not detected above elevated detection limits up to 31.3 and $3,170 \mu \mathrm{g} / \mathrm{kg}$, respectively. Analysis of the soil sample collected from beneath the pump island, however, showed concentrations of toluene (up to $43,400 \mu \mathrm{g} / \mathrm{kg}$ ), ethylbenzene (up to $18,800 \mu \mathrm{g} / \mathrm{kg}$ ), total xylenes (up to $131,000 \mu \mathrm{g} / \mathrm{kg}$ ), and TPH (up to $571,000 \mu \mathrm{g} / \mathrm{kg}$ ). Benzene was not detected above an elevated detection limit of $4,820 \mu \mathrm{g} / \mathrm{kg}$. A single ground-water sample was collected from the center of the excavation and concentrations were detected as follows: total BTEX $(58,200 \mu \mathrm{g} / \mathrm{L}), \mathrm{TPH}(278,000 \mu \mathrm{g} / \mathrm{L})$, and lead $(273 \mu \mathrm{g} / \mathrm{L})$; MTBE did not exceed the detection limit of $2,000 \mu \mathrm{g} / \mathrm{L}$.

Two 550-gal UST's used to contain fuel oil and waste oil and located directly behind the gas-station building, also were removed (General Engineering Laboratories, 1991). Numerous perforations were noted in these tanks, but the soils did not appear to be 
affected by petroleum contamination. About 50 cubic yards of soil was removed to $8 \mathrm{ft}$ bls, and the hole was backfilled with clean fill material. Ground water was not found in the excavation. Naphthalene and TPH analyses of three soil samples collected from the bottom of the excavation did not indicate measurable contamination.

Based on the evidence of petroleum contamination found during UST-removal activities, an investigation to assess the extent of contamination was initiated (General Engineering Laboratories, 1992; 1993a). Four monitoring wells (MW-1 through MW-4) were installed, and soil samples were collected with a split-spoon sampler every $3 \mathrm{ft}$ for lithologic description and photoionization-detector screening. Ground water collected from the wells was analyzed for BTEX compounds. Total BTEX concentrations ranged from less than detection limits at MW-3 to $19,850 \mu \mathrm{g} / \mathrm{L}$ at MW-1. The highest benzene concentration $(2,580 \mu \mathrm{g} / \mathrm{L})$ was detected in water from MW-4; a concentration of $139 \mu \mathrm{g} / \mathrm{L}$ was detected in water from MW-2.

After initially sampling the four monitoring wells, an expanded assessment was initiated (General Engineering Laboratories, 1993a). Ten temporary wells dug with a hand auger were installed to further address the horizontal extent of contamination. Ground-water samples for BTEX analysis were collected from the open auger holes, and the holes were backfilled after sample collection. Elevated BTEX concentrations were detected in two of the temporary wells located in the southernmost and northernmost grass islands, respectively adjacent to Ashley River Road.

Based on BTEX concentration data collected from the four monitoring wells and the temporary wells, four additional monitoring wells (MW-5 through MW-8) were installed (General Engineering Laboratories, 1993a). Well PW-1 was installed next to MW-1 and was screened in a deeper horizon than the other wells at the site. Following the installation of the additional monitoring wells, ground-water samples for the analysis of BTEX compounds and lead were collected from all monitoring wells. As was observed in the previous sampling event, elevated BTEX concentrations were detected in water samples from wells MW-1, MW-2, and MW-4. Lead was detected in water from all wells at concentrations ranging from 15 to $241 \mu \mathrm{g} / \mathrm{L}$. Because the highest lead concentrations occurred at wells where BTEX compounds were not detected, its occurrence was attributed to aquifer solids as opposed to leaded gasoline (General Engineering Laboratories, 1993a).

Negative-displacement slug tests were performed at three monitoring wells to provide estimates of aquifer hydraulic characteristics. The resulting hydraulic conductivity values ranged from 32 to $36 \mathrm{ft} / \mathrm{d}$ at wells MW-2, MW-4, and MW-6 (General Engineering Laboratories, 1993a).

Following the completion of the expanded assessment, ground-water sampling was continued on a quarterly basis (General Engineering Laboratories, 1993b, 1993c, 1994). One important finding of these monitoring events included the appearance of free-phase petroleum (approximately 0.32 -ft thick) in well MW-4 (General Engineering Laboratories, 1993b) where product recovery efforts were initiated. Free-phase petroleum was not detected in any wells during subsequent monitoring events; however, elevated concentrations of petroleum hydrocarbons (up to $36,480 \mu \mathrm{g} / \mathrm{L}$ total BTEX) persisted in well MW-4 (General Engineering Laboratories, 1993c, 1994). Additionally, MTBE was detected in water from MW-4 at a concentration of $11,900 \mu \mathrm{g} / \mathrm{L}$. Similarly, elevated BTEX concentrations (up to $9,910 \mu \mathrm{g} / \mathrm{L}$ ) persisted in well MW-1. Benzene was detected at a concentration of $1,830 \mu \mathrm{g} / \mathrm{L}$ in water from well MW-2 during the first quarterly monitoring (General Engineering Laboratories, 1993b), but was not detected in MW-2 during subsequent sampling events (General Engineering Laboratories, 1993c, 1994).

\section{Data-Collection Methods}

Standard methods were used to collect and analyze most of the data presented in this report. In some cases involving the collection of ground-water data, however, relatively new methods were used. Although considered nonstandard, sufficient technical documentation of the methods is available and referenced. Specific methods are discussed in the following sections.

\section{Temporary Well Installation}

A total of seven temporary monitoring wells, including three screened at a deeper horizon in the water-table aquifer and paired with shallow-screened temporary wells, were installed at the Laurens site. These wells are identified by the prefix "GP" followed by consecutive numbers 1 through 4 (fig. 4). Wells GP1, 
GP2, and GP4 were installed in pairs (separate holes) and are further identified to denote relative depth. The suffix "S" denotes the shallowest of the pair, screened to bracket the water table, and the suffix " $D$ " denotes the deepest of the pair, with a fully saturated screened interval. Temporary wells were installed at locations along certain flow lines or in areas where data gaps potentially existed. At the Charleston site, eight temporary monitoring wells were installed in the shallow surficial aquifer with screened intervals positioned to bracket the water table. These wells are identified by the prefix "GP-" followed by a consecutive number 1 through 8 (fig. 5).

All temporary wells were installed using directpush methods, and were constructed with 1-inch (in.) inside-diameter PVC monitor pipe and slotted screen sections. At most locations, a steel drive point and probe rod was hydraulically hammered into the surficial aquifer to the desired depth. Immediately following probe extraction, the screen and riser pipe was inserted into the open hole and pushed by hand to refusal. A solid PVC drive plug at the bottom of the screened section facilitated insertion. If the desired depth of the well was not achieved by hand pushing, the PVC pipe was hydraulically pushed to the desired depth. At two locations at the Charleston site (GP-7 and GP-8), wells were constructed in holes where continuous cores had been collected by direct-push methods (corresponding to corehole locations GPS-4 and GPS-6, respectively). Clean filter sand was poured down the sides of the hole to fill the annular space to about $2 \mathrm{ft}$ bls. Granular bentonite, which was placed in the annulus above the sand pack to about 8 in. bls, was hydrated with deionized water to create a seal. The wells were finished slightly above grade using a cam-locking, watertight manhole cover and sand-cement pad.

\section{Water-Level Measurements}

Water levels were measured at both sites on various dates to characterize the shape and slope of the water-table surface at each site. Measuring points were established at the tops of the PVC casing at all monitoring wells, and the elevation of each measuring point was determined by differential leveling to provide a common datum for water-level comparison at each site. The datum used at each site was arbitrary based on measuring-point elevations of $100.00 \mathrm{ft}$ at well MW-2 at the Laurens site and $10.00 \mathrm{ft}$ at well MW- 8 at the Charleston site.
The depth to water, relative to the established measuring point at each well, was measured to the nearest $0.01 \mathrm{ft}$ using an electric water-level indicator. Multiple measurements were taken at each well to ensure accuracy and to ensure that equilibrium had been achieved, particularly in wells with fully saturated screened intervals.

\section{Hydraulic-Conductivity Measurements}

Negative-displacement, or rising-head, slug tests were performed at several wells at each site to provide estimates of horizontal hydraulic conductivities in the water-table aquifers. At the Charleston site, water-level fluctuations were monitored during each test using a 10-pound-per-square-inch pressure transducer and a data logger. At the Laurens site, water-level recoveries were slow enough to measure with an electric waterlevel indicator. However, wells MW-3 and MW-7 were retested at a later date using a data logger and pressure transducer to monitor water-level fluctuations. All test data were analyzed using the Bouwer and Rice method (Bouwer and Rice 1976; Bouwer, 1989).

Slug tests at the Charleston site were completed at monitoring wells MW-2, MW-3, MW-5, and MW-6 on September 9, 1998. Slug tests at the Laurens site were completed at monitoring wells MW-2, MW-7, MW-8, and DW-1 on May 20, 1998, and at monitoring wells MW-1, MW-3, and MW-5 (two tests) on May 22, 1998. Additional tests were performed at wells MW-3 and MW-7 at the Laurens site on September 17, 1998.

\section{Gasoline-Range Organics Measurements in Soils and Sediments}

Soil samples were collected with direct-push methods at both sites for lithologic description and laboratory analysis of gasoline-range organics (GRO) content. Two-foot-long core samples were collected by hydraulically hammering a 1 -in. inside-diameter, thinwall, stainless-steel coring tube with a retractable, piston-type probe tip to the desired beginning depth. The probe tip was then released from its locked position, and the coring tube was advanced $2 \mathrm{ft}$ while the probe tip remained stationary. The soil sample was then retrieved; a clean coring-tube assembly was advanced to the previous terminal depth, and the process was repeated for each subsequent sample collected. An acetate tube liner facilitated sample extrusion. 
Soil samples were collected from 8 locations at the Charleston site on February 3 and 5, 1998. Soilsampling locations at the Charleston site were identified by the prefix "GPS-" followed by consecutive numbers 1 through 8 (fig. 5). Soil samples were collected from 11 locations at the Laurens site. Soilsampling locations at the Laurens site were identified by the prefix "GS" followed by consecutive numbers 1 through 11 (fig. 4). Samples were collected from locations GS1 through GS7 during January 12-13, 1998, and from locations GS8 through GS11 on February 4, 1998. Each sampled interval (2-ft length) from an individual location was further identified by the central depth where the core was collected. For example, sample GS5-17 was collected from location GS5 at the Laurens site, and the sampled interval was from 16 to $18 \mathrm{ft}$ bls. The land-surface elevation of each soil-sampling location was determined by differential leveling to provide a common datum for lithologic and chemical data comparison at each site. The datum used at each site was arbitrary based on measuring-point elevations of $100.00 \mathrm{ft}$ at well MW-2 at the Laurens site and $10.00 \mathrm{ft}$ at well MW-8 at the Charleston site.

Soil samples for laboratory analysis of GRO content were obtained from various depth intervals determined by relative depth position and indications of contamination by petroleum hydrocarbons. Four to five samples were collected for analysis from each hole at the Charleston site, and three to nine samples were collected for analysis from each hole at the Laurens site. Seven split-spoon samples were collected for replicate analysis. Samples were collected in wide-mouth glass jars and packed tightly in the jars to minimize air space. The jars were then sealed with Teflon-lined caps and were immediately placed on ice where they remained until delivery to a South Carolina Department of Health and Environmental Control certified commercial laboratory for analysis. Samples were analyzed for GRO content using USEPA method 5030/8015b (U.S. Environmental Protection Agency, 1986; 1996) and percent solids using USEPA method 160.3 (U.S. Environmental Protection Agency, 1983). Resulting GRO concentrations were reported in micrograms per kilograms based on dry weight.

\section{Ground-Water Chemistry Data Collection and Analysis}

Ground-water samples were collected for laboratory analysis and for field parameters from monitoring wells at both sites. Samples were collected from the Charleston site during June 24-25, 1998, and from the Laurens site during June 16-18, 1998.

All wells were purged and ground-water samples were collected using a peristaltic pump. A length of high-density polyethylene tubing, used in conjunction with the peristaltic pump, was dedicated to each well to eliminate the possibility of cross contamination. Each well was purged of three casing volumes prior to sampling. The 1-in. inside-diameter PVC monitoring-well pipes at the Laurens site were slow to recover, so these wells were pumped dry three times prior to sampling.

Ground-water samples were collected and analyzed for BTEX compounds and MTBE using USEPA method 8260a (U.S. Environmental Protection Agency, 1986; 1996) at a South Carolina Department of Health and Environmental Control certified commercial laboratory. Samples were collected by slowly filling $40-\mathrm{mL}$ volatile organic compound vials taking care to minimize agitation and potential volatile organic compound losses from aeration of the sample. The samples were preserved with hydrochloric acid and sealed with Teflon-septum caps. The sealed samples were inspected to ensure the absence of trapped air. If bubbles were present, the sample was discarded, and another sample was collected. The samples were immediately placed on ice for storage until delivery to the commercial laboratory. Trip blanks accompanied all samples from time of collection until delivery to the laboratory. Samples were tracked using the chain-ofcustody procedures of the laboratory.

Analysis of MTBE in ground-water samples also was accomplished using gas chromatography/mass spectrometry (GC/MS) with direct aqueous injection (DAI) (Church and others, 1997). Tert-butyl alcohol (TBA) and tert-butyl formate (TBF) also were analyzed by the DAI-GC/MS method. The DAI-GC/MS method has shown analytical agreement with conventional purgeand-trap methods for MTBE detection over a wide range of concentrations; moreover, the method is capable of concurrently detecting MTBE and TBA in water at concentrations less than $1 \mu \mathrm{g} / \mathrm{L}$ (Church and others, 1997). Samples for MTBE, TBA, and TBF analysis by DAI-GC/MS were collected by slowly filling $20-\mathrm{mL}$ 
headspace vials in a manner minimizing sample agitation. A Teflon-lined butyl-rubber stopper was crimped over the opening of the vial, leaving no headspace in the vial. The sealed samples were inspected to ensure the absence of trapped air, and samples were discarded and recollected if bubbles were present. The samples were not preserved with acid, but were placed on ice until delivered for laboratory analysis at the Oregon Graduate Institute of Science and Technology, Beaverton, Oregon.

Ground-water samples for the analysis of methane and dissolved inorganic carbon (DIC) were collected by injecting $5 \mathrm{~mL}$ of filtered water through the septated stopper of a sample-rinsed and sealed 20 - $\mathrm{mL}$ headspace vial. A syringe was used to pass the water through a 0.45 -micron porous-membrane filter. Samples were immediately placed on ice for storage until analyzed at the U.S. Geological Survey South Carolina District laboratory. Methane in the sample headspace was quantified by thermal-conductivitydetection gas chromatography, and dissolved methane concentrations were calculated using Henry's Law coefficients (Stumm and Morgan, 1981). Laboratory preparation of DIC samples included the addition of a 42.5 percent phosphoric acid solution. Headspace DIC was quantified by thermal-conductivity-detection gas chromatography. The DIC concentrations were corrected for atmospheric carbon dioxide $\left(\mathrm{CO}_{2}\right)$ present in ambient-air samples, which were collected daily in the field.

To determine concentrations of inorganic ions, ground-water samples were collected in sample-rinsed polyethylene bottles after using a syringe to pass the sample water through a 0.45 -micron porous-membrane filter. The samples were not acidified and were packed in ice until analyzed at the U.S. Geological Survey South Carolina District laboratory. Cations and anions were identified and quantified by ion-exchange chromatography using chemical suppression and conductivity detection.

Replicate samples representing greater than 10 percent of the total number of samples collected at each site also were collected for each type of laboratory analysis. Replicate samples were collected from monitoring wells MW-1 and MW-2 at the Charleston site and from monitoring wells MW-2 and MW-3 at the Laurens site.

Concentrations of dissolved oxygen, ferrous iron, sulfide, and manganese were measured in the field using Chemetrics colorimetric-test kits. Dissolved oxygen was quantified using the rhodazine-D method for concentrations less than $1 \mathrm{mg} / \mathrm{L}$ (Chemetrics, Inc., 1984; American Society for Testing and Materials,
1994) and the indigo-carmine method for concentrations greater than $1 \mathrm{mg} / \mathrm{L}$ (Gilbert and others, 1982). Ferrous iron and dissolved sulfide concentrations were determined using the phenanthroline method (method $3500-\mathrm{Fe}-\mathrm{D}$ ) and the methylene-blue method (method 4500-S ${ }^{2}$-D), respectively (American Public Health Association and others, 1998). The periodate method (method 314C) was used to determine dissolved manganese concentrations in ground water (American Public Health Association and others, 1998). Water temperature and $\mathrm{pH}$ were measured in the field using a digital $\mathrm{pH}$ meter equipped with a combination $\mathrm{pH}$ electrode and an automatic temperature compensator.

\section{Hydrogeology}

\section{Laurens Site}

The water table beneath the Laurens site occurs in a layer of residual soils (saprolite) that were formed by the decomposition of crystalline rock. The saprolitic water-table aquifer is underlain by parent bedrock, and a transitional zone of partially weathered rock exists between the two units. The upper part of the bedrock probably contains water-bearing fractures and fracture zones composing a deeper flow system that is hydraulically connected with the saprolitic aquifer; however, the extent of bedrock fracturing and interconnection of the two flow systems has not been investigated at this site. While drilling well DW-1 into the lower part of the saprolite aquifer, bedrock was thought to be about $38 \mathrm{ft}$ bls (Alpha Environmental Sciences, Inc., 1997).

According to the geologic mapping of Nelson and others (1998), the metamorphic bedrock beneath the Laurens site and the surrounding area is biotite gneiss of the Laurens thrust sheet, with possible zones of intrusive biotite granite gneiss. The mineral composition of the biotite gneiss is predominantly plagioclase, quartz, and biotite with varying texture and layering (Nelson and others, 1998).

The soils recovered during sampling activities were generally described as micaceous clayey sand, sandy clay, and clay. Dark-brown biotite was abundant in most cored intervals below 6 to $8 \mathrm{ft}$ bls. Some zones were characterized by quartz and plagioclase gravel and sand with varying amounts of biotite and clay. A 2 -ftdeep zone of weathered granite, consisting of gravelsized grains (up to $0.05 \mathrm{ft}$ ) of quartz, plagioclase feldspar, and biotite in a white clay matrix, was observed in corehole GS4. 
Horizontal hydraulic conductivities of saproliteaquifer sediments were estimated by aquifer testing at the Laurens site (table 5). Estimated hydraulic conductivity values ranged from 0.4 to $8 \mathrm{ft} / \mathrm{d}$, with an average value of $3 \mathrm{ft} / \mathrm{d}$. The average hydraulic conductivity determined during previous investigation at the site was $0.19 \mathrm{ft} / \mathrm{d}$ (Alpha Environmental Sciences, Inc., 1996; 1997).

Ground-water recharge to the water-table aquifer beneath the Laurens site and surrounding areas occurs through local infiltration of precipitation. Based on measurements recorded at the Laurens weather station, located about 2 miles (mi) west of the site, the average annual precipitation during 1961-90 was $48.54 \mathrm{in} / \mathrm{yr}$ (National Oceanic and Atmospheric Administration, 1999). Total annual precipitation measured at the Laurens weather station during 1998 was 50.83 in. Similar to conditions observed at the Charleston Airport, however, monthly precipitation totals during the summer and fall of 1998 were substantially lower than normal. The recharge rate at the Laurens site is not known. However, the average annual recharge in a North Carolina Piedmont basin, which is partially underlain by a similar rock type, was estimated by hydrograph separation techniques to be 6.71 in. (Daniel and Harned, 1998).

Ground water at the site primarily discharges to the small stream east of the property (fig. 4). Evapotranspiration also provides an important mechanism for water removal from the saprolitic aquifer. Average annual evapotranspiration during 1948-90 was 26 to 30 in. in the Laurens area (Cherry and Badr, 1998). Additionally, ground water from the saprolitic aquifer could recharge the deeper, fractured-rock flow system, depending on the extent of hydraulic connection.

The depth to the water table beneath the Laurens site varies from about 14 to $17 \mathrm{ft}$ bls in the paved area adjacent to North Harper Street to about 6 to $9 \mathrm{ft}$ bls in the eastern part of the property where land-surface elevations are lower. The water table fluctuates in response to rainfall infiltration. Water-level fluctuations of about $3.5 \mathrm{ft}$ were observed in wells in the western part of the study area, whereas fluctuations of about $2.5 \mathrm{ft}$ were observed in areas of lower landsurface elevations in the eastern part of the study area. The highest water levels observed during this investigation were measured on March 3, 1998, whereas the lowest water-level conditions were observed on September 9, 1998 (table 6).
The dominant direction of ground-water flow is toward the southeast (figs. 6 and 7). However, a more southward direction of flow was evident during low water-table conditions (fig. 7), as compared to high water-table conditions (fig. 6). Additionally, the slope of the water-table surface during low water-table conditions is much gentler than that observed during periods of high water levels. The hydraulic gradient between wells MW-2 and MW-7 ranged between 0.012 and $0.025 \mathrm{ft} / \mathrm{ft}$ during low and high water-level conditions, respectively.

\section{Charleston Site}

The unconfined surficial aquifer beneath the Charleston site consists of Quaternary terrace deposits of the Wando Formation of upper Pleistocene age. Wando Formation sediments were deposited in various environments, including barrier, backbarrier, and fluvial depositional environments, representing three transgressive/regressive cycles (McCartan and others, 1980). In the vicinity of the Charleston site, sediments of the Wando Formation have been described as clayey fine sand with clay, sand, and shell layers deposited in a backbarrier environment (McCartan and others, 1984; 1990). This description is consistent with the surficial aquifer sediments observed at the site during soil-sampling activities. Generally, the sediments beneath the site were found to be very fine to fine sand, silt, clayey sand, and clay. Soils from the 9- to $11-\mathrm{ft}$ depth interval were generally not recorded due to the presence of well-sorted, water-saturated sands. Layers containing shell material were observed in core samples from about 10 to $18 \mathrm{ft}$ bls.

The Wando Formation unconformably overlies the upper Oligocene and upper Eocene-age deposits of the Tertiary Cooper Group (herein referred to as the Cooper Marl), which includes the Ashley Formation, the Parkers Ferry Formation, and the Harleyville Formation (Ward and others, 1979). The indurated, irregular erosional surface of the youngest of these deposits, the Oligocene Ashley Formation, provides the basal contact for the Wando Formation. The Cooper Group is made up of dense, phosphatic, calcarenite and calcilutite. Based on gamma-ray logs of nearby wells (one located approximately $2 \mathrm{mi}$ west of the site), the thickness of the Cooper Group in the vicinity of the Charleston site was estimated to be about $300 \mathrm{ft}$ (Park, 1985). Sediment of the Cooper Group is dense enough that only a few feet of thickness is sufficient to retard the vertical movement 
Table 6. Measuring-point elevations and relative water-level elevations at the Laurens, S.C., site [MP, measuring point; TOC, top of casing; NA, not applicable]

\begin{tabular}{|c|c|c|c|c|c|}
\hline Well & Date & $\begin{array}{l}\text { MP elevation } \\
\text { (in feet; datum is } \\
\text { arbitrary) }\end{array}$ & $\begin{array}{l}\text { Depth to water } \\
\quad \text { (in feet) }\end{array}$ & $\begin{array}{c}\text { Water-level elevation } \\
\text { (in feet; datum is } \\
\text { arbitrary) }\end{array}$ & Remarks \\
\hline MW-1 & $\begin{array}{r}3 / 6 / 98 \\
6 / 16 / 98 \\
9 / 17 / 98 \\
4 / 13 / 99\end{array}$ & $\begin{array}{l}100.65 \\
100.65 \\
100.65 \\
100.65\end{array}$ & $\begin{array}{l}14.04 \\
14.32 \\
17.54 \\
16.38\end{array}$ & $\begin{array}{l}86.61 \\
86.33 \\
83.11 \\
84.27\end{array}$ & $\mathrm{MP}=\mathrm{Black}$ mark TOC \\
\hline MW-2 & $\begin{array}{r}3 / 6 / 98 \\
6 / 17 / 98 \\
9 / 17 / 98 \\
4 / 13 / 99\end{array}$ & $\begin{array}{l}100.00 \\
100.00 \\
100.00 \\
100.00\end{array}$ & $\begin{array}{l}13.43 \\
13.76 \\
16.97 \\
15.81\end{array}$ & $\begin{array}{l}86.57 \\
86.24 \\
83.03 \\
84.19\end{array}$ & $\mathrm{MP}=$ Black mark TOC \\
\hline MW-3 & $\begin{array}{r}3 / 6 / 98 \\
6 / 17 / 98 \\
9 / 17 / 98 \\
4 / 13 / 99\end{array}$ & $\begin{array}{l}94.29 \\
94.29 \\
94.29 \\
94.29\end{array}$ & $\begin{array}{r}9.50 \\
10.12 \\
12.17 \\
11.16\end{array}$ & $\begin{array}{l}84.79 \\
84.17 \\
82.12 \\
83.13\end{array}$ & $\mathrm{MP}=$ Black mark TOC \\
\hline MW-4 & $\begin{array}{r}3 / 6 / 98 \\
6 / 16 / 98 \\
9 / 17 / 98 \\
4 / 13 / 99\end{array}$ & $\begin{array}{l}100.34 \\
100.34 \\
100.34 \\
100.34\end{array}$ & $\begin{array}{l}13.63 \\
13.91 \\
17.22 \\
16.05\end{array}$ & $\begin{array}{l}86.71 \\
86.43 \\
83.12 \\
84.29\end{array}$ & $\mathrm{MP}=$ Black mark TOC \\
\hline MW-5 & $\begin{array}{r}3 / 6 / 98 \\
6 / 16 / 98 \\
9 / 17 / 98 \\
4 / 13 / 99\end{array}$ & $\begin{array}{l}91.65 \\
91.65 \\
91.65 \\
91.65\end{array}$ & $\begin{array}{l}6.81 \\
7.40 \\
9.40 \\
8.41\end{array}$ & $\begin{array}{l}84.84 \\
84.25 \\
82.25 \\
83.24\end{array}$ & $\mathrm{MP}=$ Black mark TOC \\
\hline MW-6 & $\begin{array}{r}3 / 6 / 98 \\
6 / 16 / 98 \\
9 / 17 / 98 \\
4 / 13 / 99\end{array}$ & $\begin{array}{l}98.05 \\
98.05 \\
98.05 \\
98.05\end{array}$ & $\begin{array}{c}11.75 \\
11.98 \\
\text { NA } \\
14.05\end{array}$ & $\begin{array}{c}86.30 \\
86.07 \\
\text { NA } \\
84.00\end{array}$ & $\begin{array}{c}\text { MP = } \text { Black mark TOC } \\
\text { Dry hole }\end{array}$ \\
\hline MW-7 & $\begin{array}{r}3 / 6 / 98 \\
6 / 16 / 98 \\
9 / 17 / 98 \\
4 / 13 / 99\end{array}$ & $\begin{array}{l}87.89 \\
87.89 \\
87.89 \\
87.89\end{array}$ & $\begin{array}{l}8.54 \\
6.03 \\
7.04 \\
6.45\end{array}$ & $\begin{array}{l}79.35 \\
81.86 \\
80.85 \\
81.44\end{array}$ & $\begin{array}{l}\text { MP = Black mark TOC } \\
\text { Measurement suspect? }\end{array}$ \\
\hline MW-8 & $\begin{array}{r}3 / 6 / 98 \\
6 / 16 / 98 \\
9 / 17 / 98 \\
4 / 13 / 99\end{array}$ & $\begin{array}{l}91.28 \\
91.28 \\
91.28 \\
91.28\end{array}$ & $\begin{array}{l}7.64 \\
8.23 \\
9.98 \\
9.04\end{array}$ & $\begin{array}{l}83.64 \\
83.05 \\
81.30 \\
82.24\end{array}$ & $\mathrm{MP}=$ Black mark TOC \\
\hline MW-9 & $\begin{array}{r}3 / 6 / 98 \\
6 / 18 / 98 \\
9 / 17 / 98 \\
4 / 13 / 99\end{array}$ & $\begin{array}{l}90.96 \\
90.96 \\
90.96 \\
90.96\end{array}$ & $\begin{array}{r}8.45 \\
9.25 \\
10.44 \\
9.56\end{array}$ & $\begin{array}{l}82.51 \\
81.71 \\
80.52 \\
81.40\end{array}$ & $\mathrm{MP}=$ Highest point $\mathrm{TOC}$ \\
\hline MW-10 & $\begin{array}{r}3 / 6 / 98 \\
6 / 18 / 98 \\
9 / 17 / 98 \\
4 / 13 / 99\end{array}$ & $\begin{array}{l}97.19 \\
97.19 \\
97.19 \\
97.19\end{array}$ & $\begin{array}{l}11.87 \\
12.42 \\
15.71 \\
14.12\end{array}$ & $\begin{array}{l}85.32 \\
84.77 \\
81.48 \\
83.07\end{array}$ & $\mathrm{MP}=$ Highest point $\mathrm{TOC}$ \\
\hline DW-1 & $\begin{array}{r}3 / 6 / 98 \\
6 / 16 / 98 \\
9 / 17 / 98 \\
4 / 13 / 99\end{array}$ & $\begin{array}{l}98.31 \\
98.31 \\
98.31 \\
98.31\end{array}$ & $\begin{array}{l}11.87 \\
12.12 \\
15.42 \\
14.23\end{array}$ & $\begin{array}{l}86.44 \\
86.19 \\
82.89 \\
84.08\end{array}$ & $\mathrm{MP}=\mathrm{Black}$ mark TOC \\
\hline GP1S & $\begin{array}{l}6 / 17 / 98 \\
9 / 17 / 98 \\
4 / 13 / 99\end{array}$ & $\begin{array}{l}89.79 \\
89.79 \\
89.79\end{array}$ & $\begin{array}{l}7.50 \\
8.60 \\
8.07\end{array}$ & $\begin{array}{l}82.29 \\
81.19 \\
81.72\end{array}$ & $\mathrm{MP}=$ Black mark TOC \\
\hline GPID & $\begin{array}{l}6 / 17 / 98 \\
9 / 17 / 98 \\
4 / 13 / 99\end{array}$ & $\begin{array}{l}89.79 \\
89.79 \\
89.79\end{array}$ & $\begin{array}{l}7.51 \\
8.56 \\
7.93\end{array}$ & $\begin{array}{l}82.28 \\
81.23 \\
81.86\end{array}$ & $\mathrm{MP}=$ Black mark TOC \\
\hline GP2S & $\begin{array}{l}6 / 17 / 98 \\
9 / 17 / 98 \\
4 / 13 / 99\end{array}$ & $\begin{array}{l}91.98 \\
91.98 \\
91.98\end{array}$ & $\begin{array}{r}8.36 \\
10.24 \\
9.41\end{array}$ & $\begin{array}{l}83.62 \\
81.74 \\
82.57\end{array}$ & $\mathrm{MP}=$ Black mark TOC \\
\hline GP2D & $\begin{array}{l}6 / 17 / 98 \\
9 / 17 / 98 \\
4 / 13 / 99\end{array}$ & $\begin{array}{l}91.95 \\
91.95 \\
91.95\end{array}$ & $\begin{array}{r}8.38 \\
10.23 \\
9.27\end{array}$ & $\begin{array}{l}83.57 \\
81.72 \\
82.68\end{array}$ & $\mathrm{MP}=$ Black mark TOC \\
\hline GP3 & $\begin{array}{l}6 / 18 / 98 \\
9 / 17 / 98 \\
4 / 13 / 99\end{array}$ & $\begin{array}{l}94.95 \\
94.95 \\
94.95\end{array}$ & $\begin{array}{l}10.72 \\
12.78 \\
11.76\end{array}$ & $\begin{array}{l}84.23 \\
82.17 \\
83.19\end{array}$ & $\mathrm{MP}=$ Black mark TOC \\
\hline GP4S & $\begin{array}{l}6 / 17 / 98 \\
9 / 17 / 98 \\
4 / 13 / 99\end{array}$ & $\begin{array}{l}98.29 \\
98.29 \\
98.29\end{array}$ & $\begin{array}{c}12.26 \\
\text { NA } \\
14.25\end{array}$ & $\begin{array}{c}86.03 \\
\text { NA } \\
84.04\end{array}$ & $\begin{array}{c}\text { MP }=\underset{\text { Black mark TOC }}{\text { Dry hole }}\end{array}$ \\
\hline GP4D & $\begin{array}{l}6 / 17 / 98 \\
9 / 17 / 98 \\
4 / 13 / 99\end{array}$ & $\begin{array}{l}98.33 \\
98.33 \\
98.33\end{array}$ & $\begin{array}{l}12.38 \\
15.53 \\
14.35\end{array}$ & $\begin{array}{l}85.95 \\
82.80 \\
83.98\end{array}$ & $\mathrm{MP}=$ Black mark TOC \\
\hline
\end{tabular}




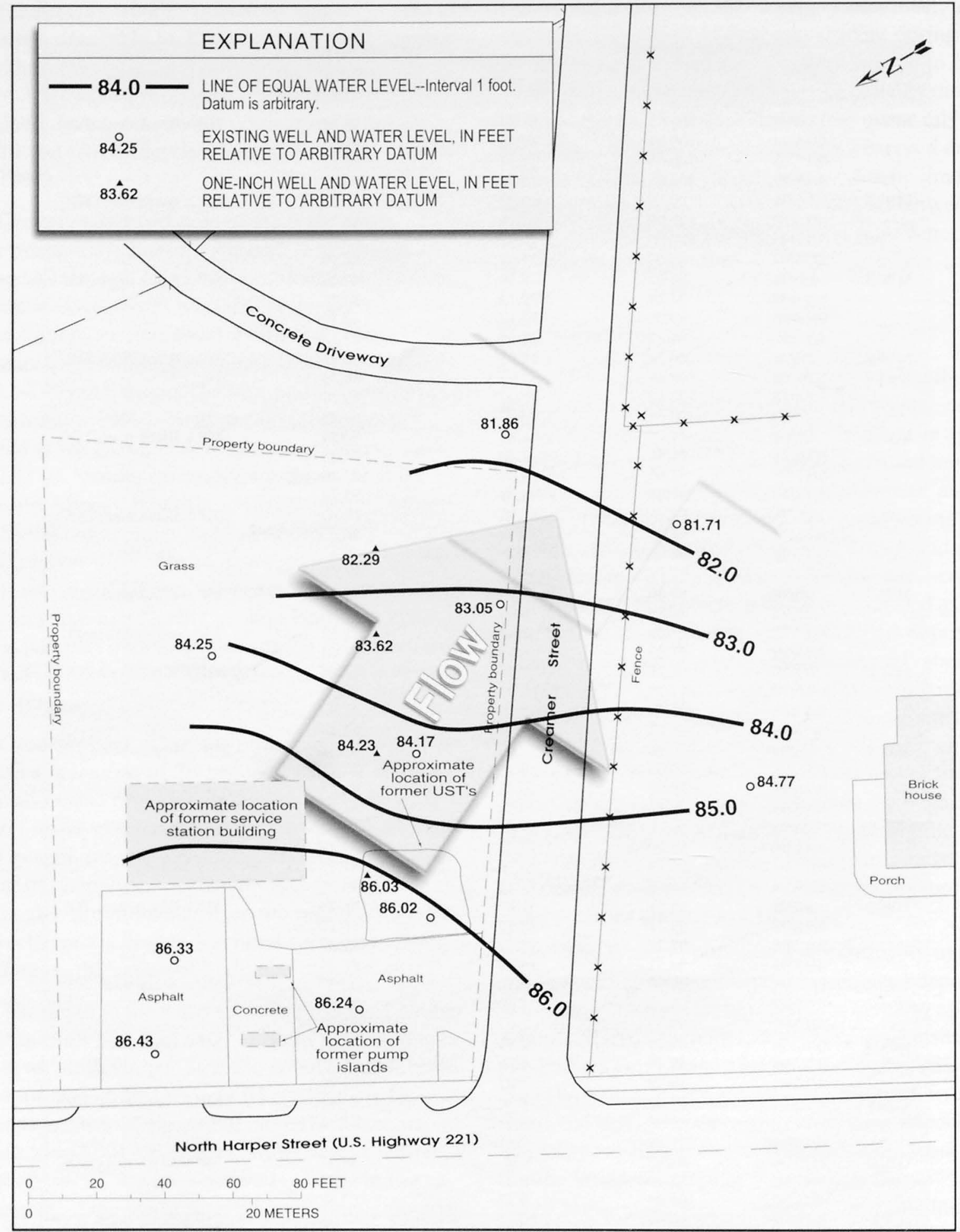

Base modified from Alpha

Environmental Sciences, Inc., 1997

Figure 6. Measured water levels at the Laurens, S.C., site, June 1998. 


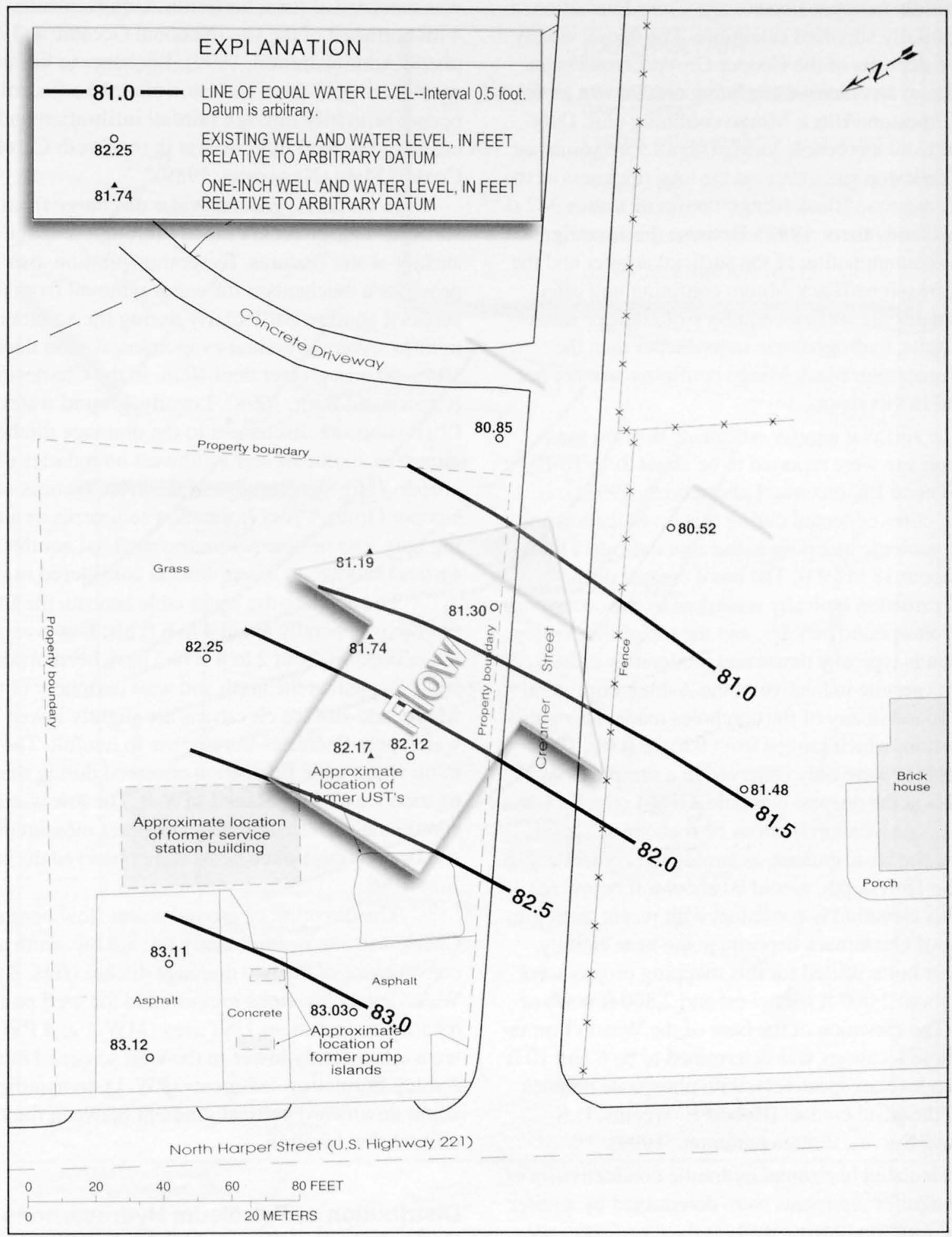

Base modified from Alpha

Environmental Sciences, Inc., 1997

Figure 7. Measured water levels at the Laurens, S.C., site, September 1998. 
of water (Park, 1985). The Cooper Group is underlain by the middle to upper Eocene-age Cross Formation, a dense, partially silicified calcilutite. The dense, areally extensive deposits of the Cooper Group/Cross Formation make up an effective confining unit known as the Santee Limestone/Black Mingo confining unit. Data collected from a corehole located about $5 \mathrm{mi}$ southeast of the Charleston site indicated the total thickness of the Santee Limestone/Black Mingo confining unit is $342 \mathrm{ft}$ (Campbell and others, 1997). Because this investigation concerns contamination of the surficial aquifer and the Santee Limestone/Black Mingo confining unit effectively isolates the surficial aquifer from deeper waterbearing units, hydrogeologic units deeper than the Santee Limestone/Black Mingo confining unit are not discussed in this report.

The surficial aquifer sediments beneath the Charleston site were reported to be about 8 - to $10-\mathrm{ft}$ thick (General Engineering Laboratories, 1993a); however, cores collected during this investigation and ongoing geologic mapping in the area indicate a thickness of about 18 to $19 \mathrm{ft}$. The basal contact of the Wando Formation typically is marked by the occurrence of black phosphatic pebbles, and the top of the Ashley Formation is typically dense and moderately indurated. Dense calcarenite indicative of the Ashley Formation was not found in any of the coreholes made during this investigation, which ranged from 9 to $18 \mathrm{ft}$ bls. Phosphate pebbles were only observed in a sample from 17 to $18 \mathrm{ft}$ bls at the deepest corehole, GPS-1 (fig. 5). Land surface at this location is about $12 \mathrm{ft}$ above sea level; therefore, the basal contact, assuming the contact is just below the $18-\mathrm{ft}$ depth, would be about $6 \mathrm{ft}$ below sea level. This elevation is consistent with recent geologic mapping of Quaternary deposits in the near vicinity. Two auger holes drilled for this mapping project were located about 2,000 ft southwest and 2,800 ft north of the site. The elevation of the base of the Wando Formation at these locations was determined to be 6 and $10 \mathrm{ft}$ below sea level, respectively, with phosphate pebbles marking the basal contact (Robert E. Weems, U.S. Geological Survey, written commun., 1999).

Calculated horizontal hydraulic conductivities of surficial aquifer sediments were determined by aquifer testing at four monitoring wells at the Charleston site (table 5). Estimated hydraulic conductivity values ranged from 20 to $40 \mathrm{ft} / \mathrm{d}$, with an average value of $30 \mathrm{ft} / \mathrm{d}$. The average hydraulic conductivity value determined during previous investigation at the site was $35 \mathrm{ft} / \mathrm{d}$ (General Engineering Laboratories, 1993a).
Annual precipitation for 1961-90 (51.53 in/yr) was recorded at the Charleston Airport, located about 4 mi northeast of the site (National Oceanic and Atmospheric Administration, 1999). Recharge to the surficial aquifer beneath the Charleston site and adjacent areas occurs primarily through rainfall infiltration and was estimated to be $6 \mathrm{in} / \mathrm{yr}$ or less in the South Carolina Coastal Plain (Newcome, 1989).

In this area, ground-water discharge from the surficial aquifer occurs mostly through seepage to surface-water features. Evapotranspiration also provides a mechanism for water removal from the surficial aquifer, particularly during the summer months. Average annual evapotranspiration during 1948-90 was greater than $40 \mathrm{in}$. in the Charleston area (Cherry and Badr, 1998). Locally, ground water at the Charleston site discharges to the drainage ditches along the southeast and southwest boundaries of the property (fig. 5). Because of the effectiveness of the Cooper Group/Cross Formation sediments as a confining unit, loss of water from the surficial aquifer by vertical leakage to lower units is considered minimal.

The depth to the water table beneath the Charleston site is generally about 4 to $6 \mathrm{ft}$ bls; however, shallower depths (about 2 to $4 \mathrm{ft}$ bls) have been observed in wells located on the north and west periphery of the site where land-surface elevations are slightly lower. The water table fluctuates in response to rainfall. The maximum water-table fluctuation observed during this investigation was $2.61 \mathrm{ft}$ at well MW-8. The low water-table conditions, reflected by depth to water measurements and dry drainage-ditch beds, were observed during June 1998.

The direction of ground-water flow beneath the Charleston site is dominantly toward the south and the convergence of the two drainage ditches (figs. 8 and 9). Water-level elevations measured at the well pair located in the former UST area (MW-1 and PW-1) were consistently lower in the well screened in the Ashley Formation sediments (PW-1), indicating a slight downward vertical gradient between the two units at that location.

\section{Distribution of Petroleum Hydrocarbons in Sediments and Ground Water}

Various methods were integrated to assess the horizontal and vertical distribution of petroleum hydrocarbons in the saturated and unsaturated zones of the water-table aquifers beneath both sites. Soil samples 


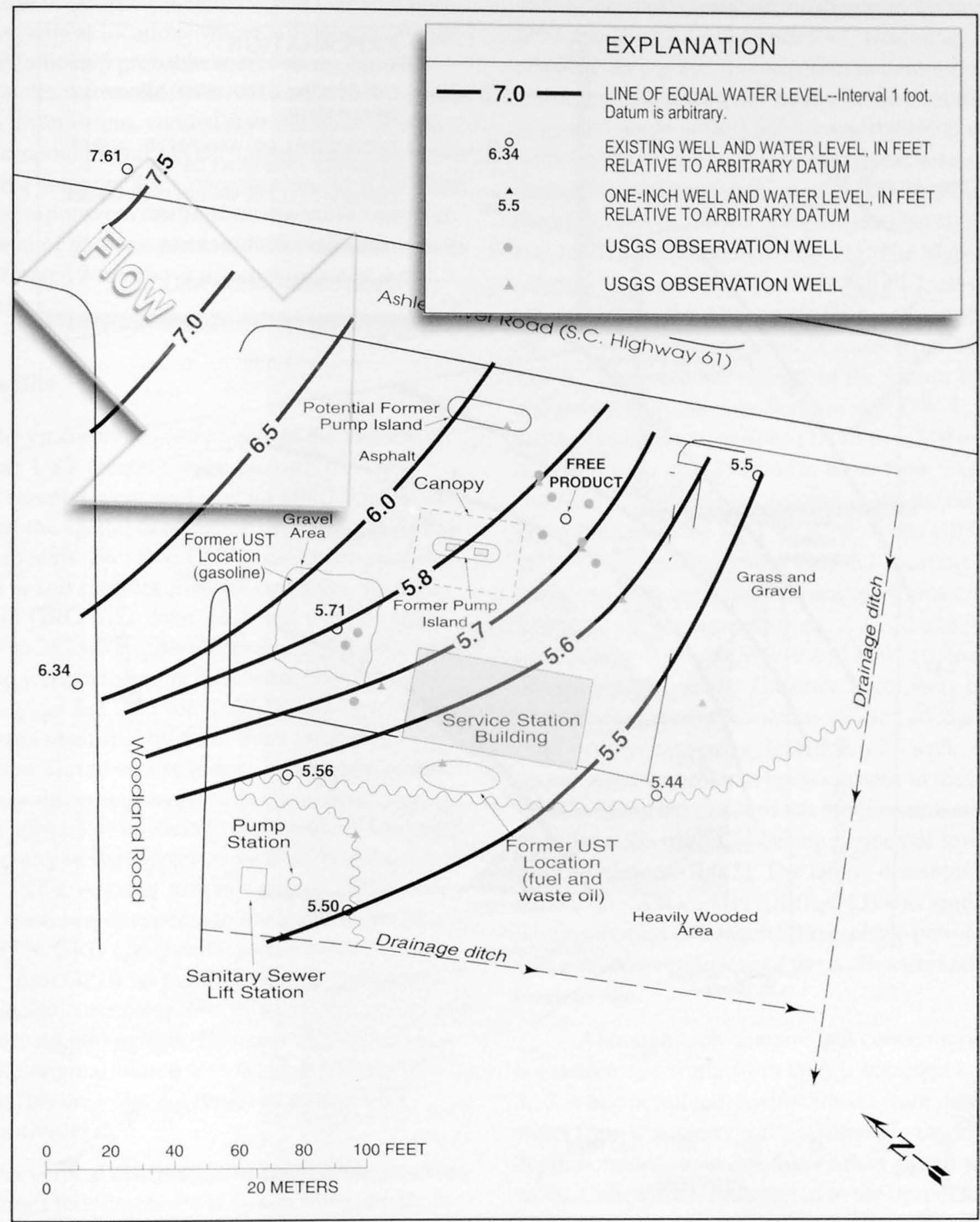

Base modified from General

Engineering Laboratories, 1993

Figure 8. Measured water levels at the Charleston, S.C., site, December 1997. 


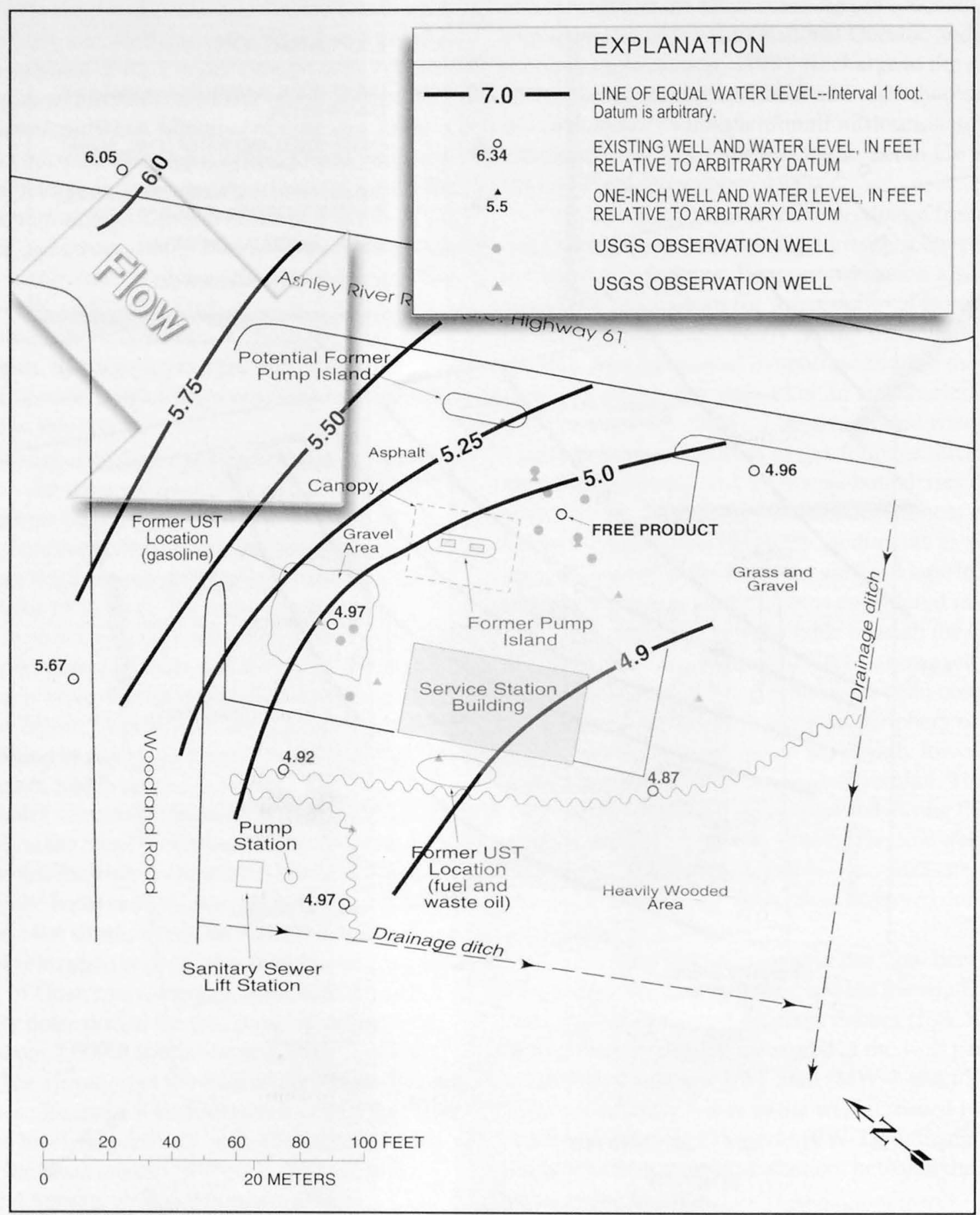

Base modified from General

Engineering Laboratories, 1993

Figure 9. Measured water levels at the Charleston, S.C., site, September 1998. 
were collected to determine the horizontal and vertical distribution of petroleum-hydrocarbon contamination in aquifer soils at locations where previous investigations had indicated probable source areas. Groundwater samples were collected to determine the horizontal and, to a lesser extent, vertical distribution of soluble BTEX compounds and MTBE, among the most mobile of gasoline components. Concentrations of BTEX and MTBE in vapor were examined to assess the vertical distribution of gaseous-phase volatile contaminants in the unsaturated zone above the contaminated watertable surface.

\section{Laurens Site}

Eleven coreholes were made in the vicinity of the former UST location at the Laurens site, and selected samples were analyzed for GRO content to determine the spatial distribution of petroleum hydrocarbons in soils. Elevated GRO concentrations were detected in soil samples from all coreholes. Concentrations of GRO were detected in soil samples from GS9 (up to $252,000 \mu \mathrm{g} / \mathrm{kg}$ ). Elevated GRO concentrations also were detected in soils from GS4 (up to $67,100 \mu \mathrm{g} / \mathrm{kg}$ ) and GS5 (up to $65,500 \mu \mathrm{g} / \mathrm{kg}$ ), indicating the area identified by these three coreholes as a source area. Based on site history and known groundwater-flow directions, hydrocarbon contamination in this area appears to be derived from leaking feed pipes in the vicinity of the former pump islands and not from leaking UST's. Another area of elevated GRO concentrations, however, does seem to be related to the release from UST's. GRO concentrations were detected in samples from GP10 (as much as $84,500 \mu \mathrm{g} / \mathrm{kg}$ ) and from adjacent coreholes GS3 (up to $31,500 \mu \mathrm{g} / \mathrm{kg}$ ) and GS7 (up to $44,600 \mu \mathrm{g} / \mathrm{kg}$ ). This area may represent a part of the original source derived from leaking UST's; soil from this area was not removed during UST closure activities.

The vertical distribution of GRO concentrations in soils from four coreholes is shown in figure 10. In general, the highest concentrations were detected in samples collected near the water table. Concentrations greater than $10,000 \mu \mathrm{g} / \mathrm{kg}$ generally occur within an approximate 5 - to $10-\mathrm{ft}$ vertical interval that brackets the water table, suggesting contaminant smearing on sediments in response to water-table fluctuations. Visual indication of free-phase petroleum in soil samples was not observed.
Ground-water samples were collected from monitoring wells installed during previous investigations and from 1-in-diameter PVC temporary wells installed during this investigation to determine the distribution of petroleum-hydrocarbon contamination in ground water at the Laurens site (tables 6 and 7). With regard to elevated concentrations, benzene seemed to be the most ubiquitous BTEX compound; therefore, it was chosen to depict the lateral distribution of BTEX compounds (fig. 11). The highest concentrations of benzene $(28,300 \mu \mathrm{g} / \mathrm{L})$, ethylbenzene $(3,260 \mu \mathrm{g} / \mathrm{L})$, toluene $(66,700 \mu \mathrm{g} / \mathrm{L})$, and MTBE $(64,178 \mu \mathrm{g} / \mathrm{L})$ were detected in water from well MW-6, located in the vicinity of the former UST's and paired with the deep horizon well DW-1. High contaminant concentrations $(1,540$ to $6,710 \mu \mathrm{g} / \mathrm{L}$ of benzene) were also detected in water from wells MW-1 and MW-2, respectively, located in the paved area, upgradient from the UST location. Wells GP3 and MW-3, downgradient from the UST location, also contained high contaminant concentrations exemplified by benzene concentrations of 2,210 and $993 \mu \mathrm{g} / \mathrm{L}$, respectively. At wells MW-9 and MW-10, located on private property across Creamer Street, only benzene was detected at concentrations $(67$ and $64.6 \mu \mathrm{g} / \mathrm{L}$, respectively) exceeding the $\mathrm{RBSL}$ of $5 \mu \mathrm{g} / \mathrm{L}$. The occurrence of petroleum hydrocarbons in these off-site wells is likely the result of the more southward general flow direction observed during periods of low watertable conditions (fig. 7). The lateral distribution of MTBE (fig. 12) and BTEX (fig. 13) was similar to the distribution of benzene. Free-phase petroleum was not observed in any of the wells sampled at the Laurens site.

Although high contaminant concentrations were not detected in water from DW-1, screened at 30.8 to $33.3 \mathrm{ft}$ bls, petroleum hydrocarbons were detected in water from temporary wells screened in the 13 - to $18-\mathrm{ft}$ depth horizon, about $5 \mathrm{ft}$ deeper than paired shallow wells. Concentrations detected in the deeper temporary wells were generally similar, if not slightly higher, than concentrations detected in the adjacent shallower wells. Benzene and MTBE concentrations exceeded the respective RBSL's of 5 and $40 \mu \mathrm{g} / \mathrm{L}$ in well pair GP4S/GP4D. Benzene was detected at concentrations exceeding the RBSL in water from GP1S/GP1D and GP2S. Water from GP2D did not contain concentrations exceeding RBSL's. 

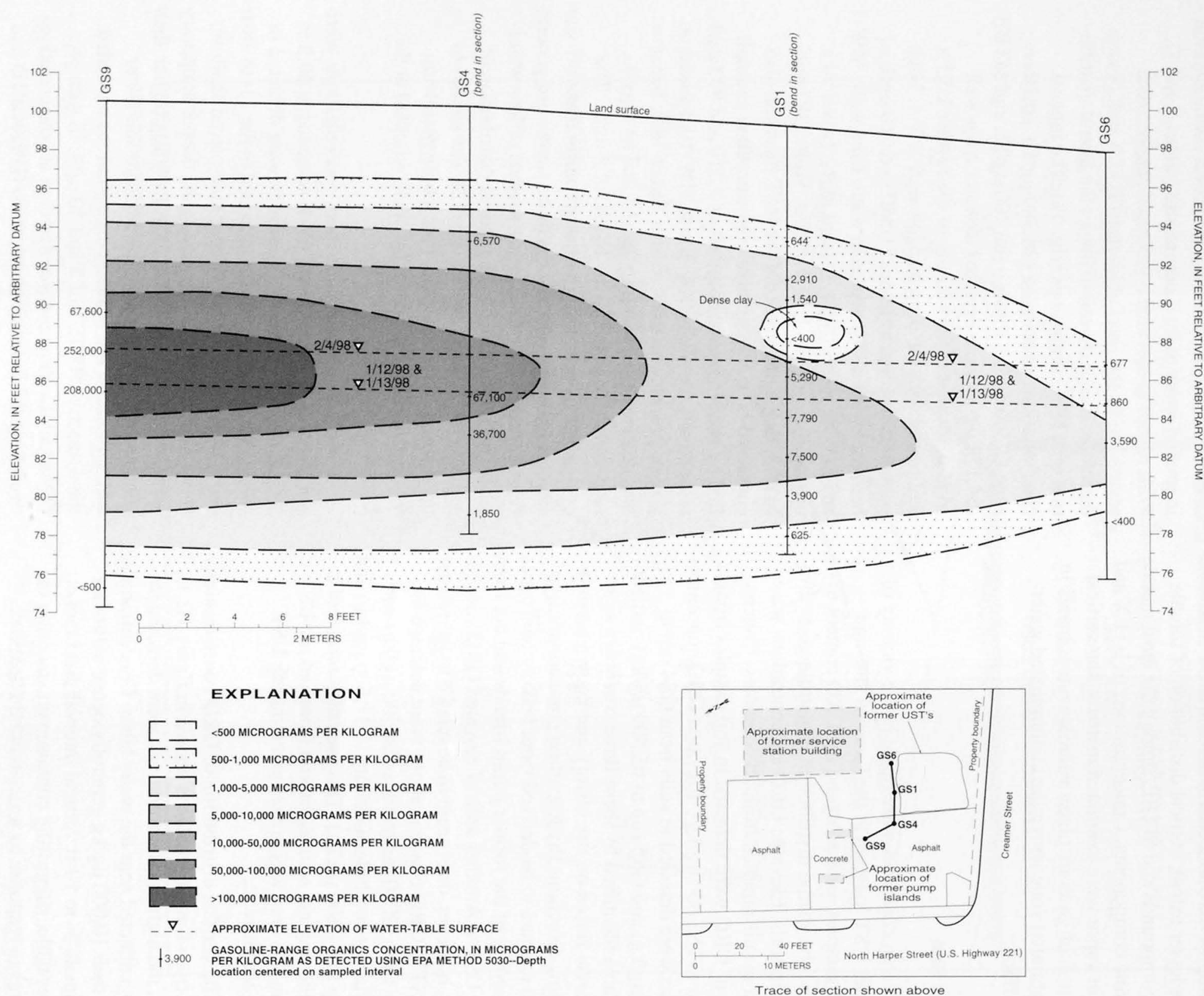

Figure 10. Vertical distribution of gasoline-range organics (GRO) in sediments along section GS9-GS6 at the Laurens, S.C., site. 
Table 7. Concentrations of dissolved petroleum hydrocarbons at the Laurens, S.C., site

[USEPA, U.S. Environmental Protection Agency; DAI-GC/MS, direct aqueous injection-gas chromatography/mass spectrometry; MTBE, methyl tert-butyl ether; TBA, tert-butyl alcohol; <, less than; R, replicate sample; ND, not detected; NA, not analyzed or applicable; RBSL, risk-based screening level. Tert-butyl formate (TBF) was analyzed using DAI-GC/MS, but was not detected in any sample above its detection limit of 5 micrograms per liter. All concentrations are reported in micrograms per liter]

\begin{tabular}{|c|c|c|c|c|c|c|c|c|}
\hline \multirow[b]{2}{*}{ Well } & \multicolumn{5}{|c|}{ Analyzed by USEPA method 8260} & \multicolumn{2}{|c|}{ Analyzed by method DAI-GC/MS } & \multirow[b]{2}{*}{ Comments } \\
\hline & Benzene & $\begin{array}{c}\text { Ethyl- } \\
\text { benzene }\end{array}$ & Toluene & $\begin{array}{l}\text { Total } \\
\text { xylenes }\end{array}$ & MTBE & MTBE & TBA & \\
\hline MW-1 & 1,540 & 6.9 & $<5$ & 22.8 & 155 & 140 & 979 & \\
\hline MW-2 & 6,710 & 2,770 & 39,800 & 15,400 & 12,900 & 7,300 & 1,035 & Upgradient of former tank area \\
\hline$M W-2 R$ & 2,280 & 2,930 & 5,420 & 7,460 & 7,260 & 9,471 & 658 & Field replicate sample \\
\hline MW-3 & 993 & 391 & 703 & 2,210 & 389 & 217 & 59.6 & \\
\hline MW-3R & 977 & 360 & 624 & 2,070 & 357 & 204 & 55.2 & Field replicate sample \\
\hline MW-4 & $<5$ & $<5$ & $<5$ & $<15$ & $<5$ & $<.10$ & $<.10$ & \\
\hline MW-5 & $<5$ & $<5$ & $<5$ & $<15$ & $<5$ & $<.10$ & $<.10$ & \\
\hline MW-6 & 28,300 & 3,260 & 66,700 & $<7,500$ & ND & 64,178 & 13,294 & Former tank area well \\
\hline MW-7 & $<5$ & $<5$ & $<5$ & $<15$ & $<5$ & $<.10$ & $<.10$ & \\
\hline MW-8 & $<5$ & $<5$ & $<5$ & $<15$ & $<5$ & $<.10$ & $<.10$ & \\
\hline MW-9 & 67 & $<5$ & 11.3 & $<15$ & 22.5 & .57 & 40.8 & \\
\hline MW-10 & 64.6 & $<5$ & 8.6 & $<15$ & 24.1 & 13.2 & 23 & \\
\hline DW-1 & $<5$ & 5.6 & 47.3 & $<15$ & $<5$ & $<.10$ & $<.10$ & Deep-horizon well; former tank area \\
\hline GP1S & 14 & 10.9 & 61.4 & 64.1 & $<5$ & $<.10$ & $<.10$ & 1-inch well; shallowest of pair \\
\hline GPID & 17.8 & 15.3 & 141 & 86.9 & 7.8 & $<.10$ & $<.10$ & 1-inch well; deepest of pair \\
\hline GP2S & 8.3 & 7.2 & 24.6 & $<15$ & 9.5 & 3.9 & $<.10$ & 1-inch well; shallowest of pair \\
\hline GP2D & $<5$ & 7.3 & 72.1 & $<15$ & 7.2 & $<.10$ & $<.10$ & 1-inch well; deepest of pair \\
\hline GP3 & 2,210 & 2,090 & 14,400 & 10,200 & 1,060 & 1,426 & 334 & 1-inch well \\
\hline GP4S & 547 & 350 & 150 & 875 & 505 & 282 & 26.9 & 1-inch well; shallowest of pair \\
\hline GP4D & 726 & 497 & 305 & 980 & 727 & 39.6 & 4.16 & 1-inch well; deepest of pair \\
\hline TP-1 & $<5$ & $<5$ & $<5$ & $<15$ & $<5$ & NA & $\mathrm{NA}$ & Trip blank \\
\hline TP-2 & $<5$ & $<5$ & $<5$ & $<15$ & $<5$ & NA & NA & Trip blank \\
\hline RBSL & 5 & 700 & 1,000 & 10,000 & 40 & 40 & NA & $\begin{array}{l}\text { (South Carolina Department of Health } \\
\text { and Environmental Control, 1995) }\end{array}$ \\
\hline
\end{tabular}

Petroleum hydrocarbons were not detected above respective detection limits in water from wells MW-4, MW-5, MW-7, and MW-8. Analysis of trip blanks that accompanied water samples from the Laurens site did not detect concentrations of BTEX compounds or MTBE above respective detection limits.

\section{Charleston Site}

Soil samples were collected from two source areas at the Charleston site, the former location of the UST's and the area around well MW-4 (fig. 5), and selected samples were analyzed for GRO content to determine the spatial distribution of petroleum hydrocarbons in soils near source areas. Cores were initially

obtained from two locations in the vicinity of the former gasoline UST's; GPS-1 and GPS-2, located in the excavation area and on the southern edge (downgradient) of the excavation, respectively. Soil recovery from the tank area was generally poor, probably because of the loosely compacted characteristic of the fill material. GRO was detected in a nonsaturated sample from GPS-1 $(2,010 \mu \mathrm{g} / \mathrm{kg})$ from a depth of $3 \mathrm{ft}$. Analysis of samples collected from near and below the water table at GPS-1 did not detect GRO concentrations above the detection limit of $500 \mu \mathrm{g} / \mathrm{kg}$. At GPS-2, a GRO was detected at GPS-2 $(36,000 \mu \mathrm{g} / \mathrm{kg})$ in a sample from a depth of $9 \mathrm{ft}$, but elevated concentrations were not detected at other sampled intervals both above and below $9 \mathrm{ft}$. 


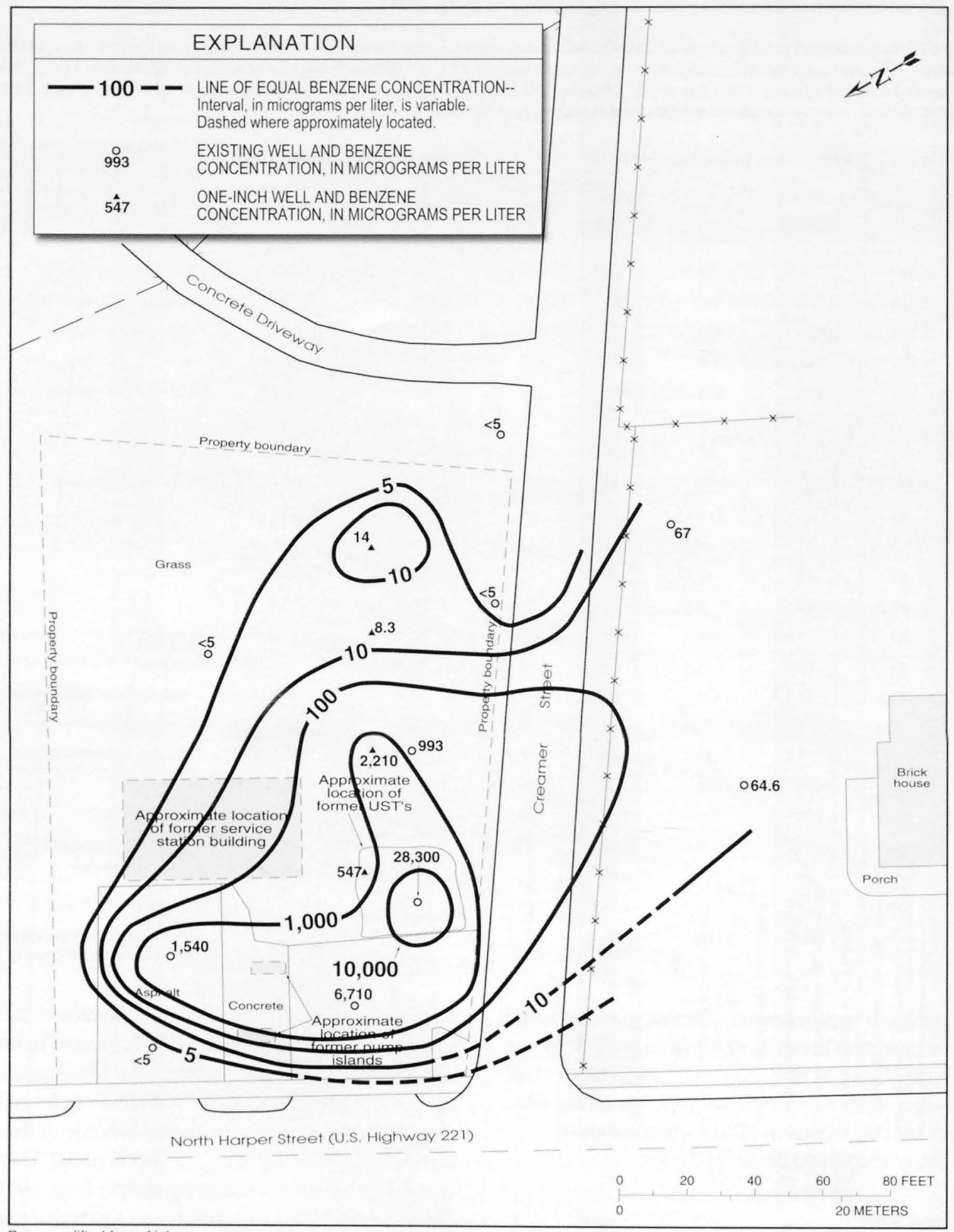

Base modified from Alpha

Environmental Sciences, Inc., 1997

Figure 11. Distribution of benzene at the Laurens, S.C., site, June 1998. 


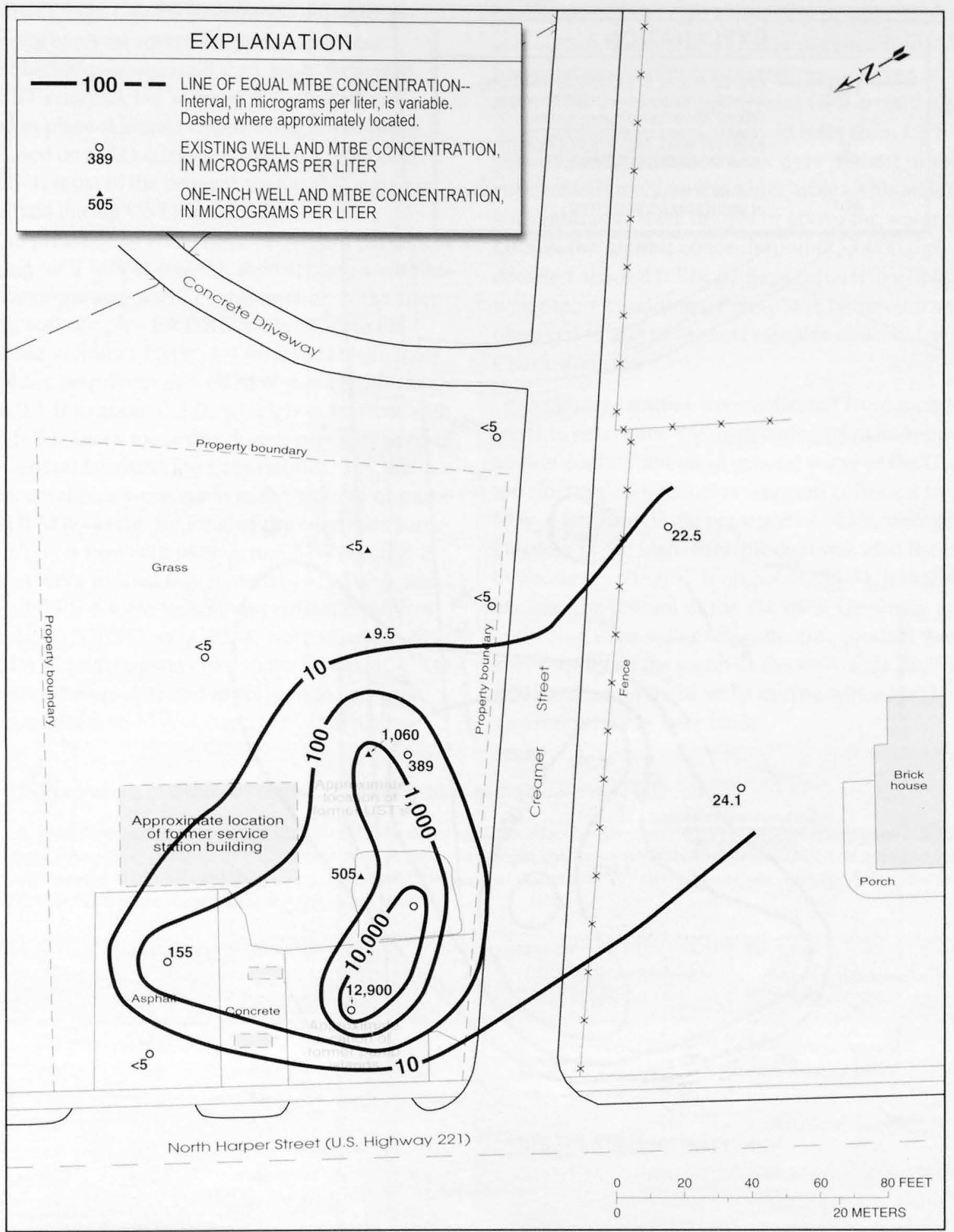

Base modified from Alpha

Environmental Sciences, Inc., 1997

Figure 12. Distribution of methyl tert-butyl ether (MTBE) at the Laurens, S.C., site, June 1998. 


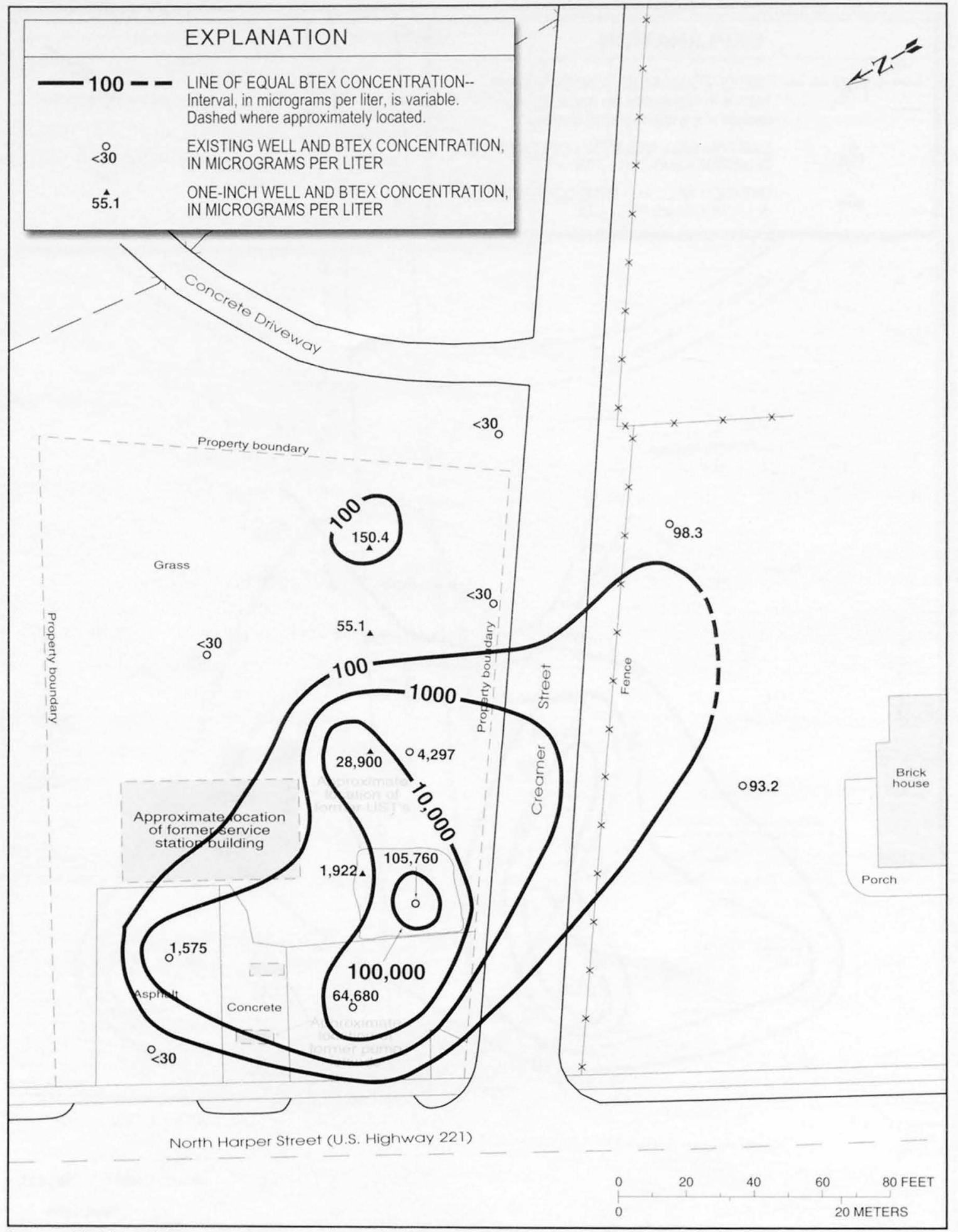

Base modified from Alpha

Environmental Sciences, Inc., 1997

Figure 13. Distribution of benzene, toluene, ethylbenzene, and total xylenes (BTEX) at the Laurens, S.C., site, June 1998. 
The relatively high GRO concentration detected at GPS-2 may represent source-area concentrations. The most highly contaminated soils were excavated during UST removal, but some of the affected soils remained in place (General Engineering Laboratories, 1991). Based on GRO concentrations in soils collected from GPS-1, most of the original source area apparently was removed during UST closure activities.

The presence of free-phase petroleum persists at monitoring well MW-4 (fig. 5), representing a continuing source of ground-water contamination at the site; therefore, soil samples for GRO analysis were collected in the vicinity of MW-4. Observed thicknesses of free-phase petroleum in well MW-4 ranged from less than $0.1 \mathrm{ft}$ to about $0.5 \mathrm{ft}$, which is consistent with the 0.32 -ft thickness measured during previous investigation (General Engineering Laboratories, 1993b).

Six coreholes were made in the vicinity of monitoring well MW-4 (fig. 5). Four of the coreholes were situated along a flowpath intersecting MW-4; GPS-3 and GPS-4 were located downgradient of MW-4, and GPS-5 and GPS-6 were located upgradient of MW-4. Two coreholes, GPS-7 and GPS-8, were situated adjacent to MW-4 and perpendicular to the flowpath. GRO concentrations were detected in soils collected from coreholes adjacent to MW-4 (up to $262,000 \mu \mathrm{g} / \mathrm{kg}$ ).
Concentrations of GRO were less in soils from GPS-3 and GPS-6, located at a greater distance from MW-4; however, maximum concentrations detected in soils from GPS-3 $(45,000 \mu \mathrm{g} / \mathrm{kg})$ and GPS-6 $(967 \mu \mathrm{g} / \mathrm{kg})$ were substantial, particularly in soils from GPS-3. In general, GRO concentrations were highest in samples collected at or above the water table. Although GRO concentrations were high at or above the water table at GPS-8, the highest concentration $(252,000 \mu \mathrm{g} / \mathrm{kg})$ was detected about $8 \mathrm{ft}$ bls, perhaps reflective of past low water-table conditions. Free-phase petroleum was not observed in any of the soil samples collected at the Charleston site.

Water samples were collected from monitoring wells to determine the distribution of petroleum-hydrocarbon contamination in ground water at the Charleston site (table 8). Samples were not collected from well MW-4 because of the presence of black, weathered gasoline in the well. Free product was also detected in temporary well GP-7 (corehole GPS-4); however, because the bottom of the screen at GP-7 was apparently above the water table, the free product was probably trapped in the sump of the well. Free product also was detected in these wells during water-level measurements at later dates.

Table 8. Concentrations of dissolved petroleum hydrocarbons at the Charleston, S.C., site

[USEPA, U.S. Environmental Protection Agency; DAI-GC/MS, direct aqueous injection-gas chromatography/mass spectrometry; MTBE, methyl tert-butyl ether; TBA, tert-butyl alcohol; <, less than; R, replicate sample; NA, not analyzed or applicable; RBSL, risk-based screening level. Tert-butyl formate (TBF) was analyzed using DAI-GC/MS, but was not detected in any sample above its detection limit of 5 micrograms per liter. All concentrations are reported in micrograms per liter]

\begin{tabular}{|c|c|c|c|c|c|c|c|c|}
\hline \multirow[b]{2}{*}{ Well } & \multicolumn{5}{|c|}{ Analyzed by USEPA method 8260} & \multicolumn{2}{|c|}{ Analyzed by method DAI-GC/MS } & \multirow[b]{2}{*}{ Comments } \\
\hline & Benzene & $\begin{array}{l}\text { Ethyl- } \\
\text { benzene }\end{array}$ & Toluene & $\begin{array}{c}\text { Total } \\
\text { xylenes }\end{array}$ & MTBE & MTBE & TBA & \\
\hline MW-1 & 434 & 36.6 & 6.2 & $<15$ & 138 & 161 & 2,094 & Former tank area well \\
\hline MW-1R & 532 & 45.1 & 6.2 & $<15$ & 138 & 139 & 1,928 & Field replicate sample \\
\hline MW-2 & 210 & 5.4 & 5.9 & $<15$ & 5.4 & 1.54 & 26.3 & \\
\hline MW-2R & 286 & 7.8 & 5.5 & $<15$ & 7.9 & 2.68 & 55.6 & Field replicate sample \\
\hline MW-3 & $<5$ & $<5$ & $<5$ & $<15$ & $<5$ & $<.10$ & $<.10$ & \\
\hline MW-4 & NA & NA & NA & NA & NA & NA & NA & Well contains free-phase petroleum \\
\hline MW-5 & $<5$ & $<5$ & $<5$ & $<15$ & $<5$ & $<.10$ & $<.10$ & \\
\hline MW-6 & $<5$ & $<5$ & $<5$ & $<15$ & $<5$ & $<.10$ & 28.5 & \\
\hline MW-7 & $<5$ & $<5$ & $<5$ & $<15$ & $<5$ & $<.10$ & $<.10$ & \\
\hline MW-8 & $<5$ & $<5$ & $<5$ & $<15$ & $<5$ & $<.10$ & $<.10$ & \\
\hline PW-1 & $<5$ & $<5$ & $<5$ & $<15$ & 20.2 & 4.81 & 390 & Deep-horizon well; former tank area \\
\hline TB-1 & $<5$ & $<5$ & $<5$ & $<15$ & $<5$ & NA & NA & Trip blank \\
\hline TB-2 & $<5$ & $<5$ & $<5$ & $<15$ & $<5$ & NA & NA & Trip blank \\
\hline RBSL & 5 & 700 & 1,000 & 10,000 & 40 & 40 & NA & $\begin{array}{l}\text { (South Carolina Department of Health } \\
\text { and Environmental Control, 1995) }\end{array}$ \\
\hline
\end{tabular}


Analysis of BTEX compounds in water samples from other monitoring wells indicated the presence of benzene, ethylbenzene, and toluene above detection limits only in wells MW-1 and MW-2, located in the vicinity of the former UST location (table 8). Replicate samples were collected at both of these wells. Total xylenes were not detected above the detection limit of $15 \mu \mathrm{g} / \mathrm{L}$ in water from any well. Benzene was the only BTEX compound detected at concentrations above the respective RBSL of $5 \mu \mathrm{g} / \mathrm{L}$. Benzene was detected in water from MW-1 (434 and $532 \mu \mathrm{g} / \mathrm{L}$ ) and in water from MW-2 (210 and $286 \mu \mathrm{g} / \mathrm{L}$ ) (table 8). Methyl tert-butyl ether was detected using both analytical methods (USEPA 8260 and DAI-GC/MS) in water from wells MW-1, MW-2, and PW-1, the deep horizon well paired with MW-1 in the former UST area. However, MTBE concentrations exceeded the respective RBSL of $40 \mu \mathrm{g} / \mathrm{L}$ only in water from MW-1 (up to $161 \mu \mathrm{g} / \mathrm{L}$ ). Tert-butyl alcohol was detected in water from MW-1 (up to 2,094 $\mu \mathrm{g} / \mathrm{L}$ ), MW-2 (up to $55.6 \mu \mathrm{g} / \mathrm{L}), \mathrm{MW}-6(28.5 \mu \mathrm{g} / \mathrm{L})$, and PW-1 $(390 \mu \mathrm{g} / \mathrm{L})$. The occurrence of MTBE and TBA in water from PW-1 may indicate the leading edge of downward contaminant migration at this location. Given the slight downward gradient measured at the well pair and the greater solubility of TBA and MTBE as compared to the BTEX compounds, TBA and MTBE would potentially appear at deeper horizons prior to BTEX compounds. Tert-butyl formate was not detected above its detection limit of $5 \mu \mathrm{g} / \mathrm{L}$ in water from any monitoring well. Petroleum hydrocarbons were not detected above respective detection limits in water from wells MW-3, MW-5, MW-7, and MW-8 (table 8). Analysis of trip blanks that accompanied water samples from the Charleston site did not detect concentrations of BTEX compounds or MTBE above respective detection limits.

\section{Natural Attenuation of Petroleum Hydrocarbons in Ground Water}

Once the contaminant source and the contaminant plume have been delineated, and the hydrologic, geochemical, and biologic properties of the site characterized, the natural attenuation of petroleum hydrocarbons can be assessed in step-by-step process as outlined in fig. 2. In the following sections, the natural attenuation of petroleum hydrocarbons is assessed at the Laurens and Charleston sites using this methodology.

\section{Laurens Site}

Step 1-Delineation of source area. The approximate distribution of petroleum hydrocarbons in the source area is shown in fig. 14. This delineation is based partly on site history and records of the locations of underground tanks and distribution lines. In addition, the amount of GRO petroleum hydrocarbons present in subsurface sediments have been measured by coring sediments.

\section{Step 2-Define areal and vertical extent of contaminant} plume. The areal distribution of dissolved petroleum hydrocarbons is shown in figures 11,12 , and 13 . The highest measured aqueous concentrations of contaminants in the source area are from MW-6, with benzene concentrations $28,300 \mu \mathrm{g} / \mathrm{L}$, and MTBE concentrations of $64,178 \mu \mathrm{g} / \mathrm{L}$ (table 7 ). The core of the plume - that is, that part of the plume that carries the greatest concentrations away from the source area-is centered on wells GS5, GP4, GP2, and GP1. The approximate vertical extent of the plume downgradient of the source area is indicated by the presence of dissolved petroleum hydrocarbons in deeply screened (GP2D, GP1D) and shallow-screened (GP2S, GP1S) geoprobe wells. These data indicate that the plume has spread laterally as well as immediately downgradient of the contaminantsource areas, and that higher concentrations of contaminants are present near the top of the water table rather than deeper in the saturated zone. This observed distribution reflects hydrologic transport of dissolved contaminants away from the source area.

\section{Step 3-Quantify hydrologic characteristics of the} aquifer. The Laurens site is underlain by saprolitic material characteristic of the South Carolina Piedmont. Slug tests at this site (table 5) indicate that the hydraulic conductivity ranges from 0.4 to $8 \mathrm{ft} / \mathrm{d}$ with an average value of $3 \mathrm{ft} / \mathrm{d}$. Previous investigations indicated an average hydraulic conductivity of $0.3 \mathrm{ft} / \mathrm{d}$ (Alpha Environmental Services, Inc., 1996, 1997). Depth to the water table varies from about 14 to $17 \mathrm{ft}$ bls near the source area. Ground-water flow is to the southeast, with ground water discharging to a small stream located about $200 \mathrm{ft}$ from the source area. Water-table fluctuations are substantial in response to rainfall events (figs. 6 and 7). These data indicate that the rate and directions of ground-water flow are variable at this site, and may contribute to the dispersion of the contaminant plume as it moves away from the source area. The hydraulic gradient at the site varies from about 0.01 to $0.02 \mathrm{ft} / \mathrm{ft}$, and rates of ground-water flow vary accordingly. 


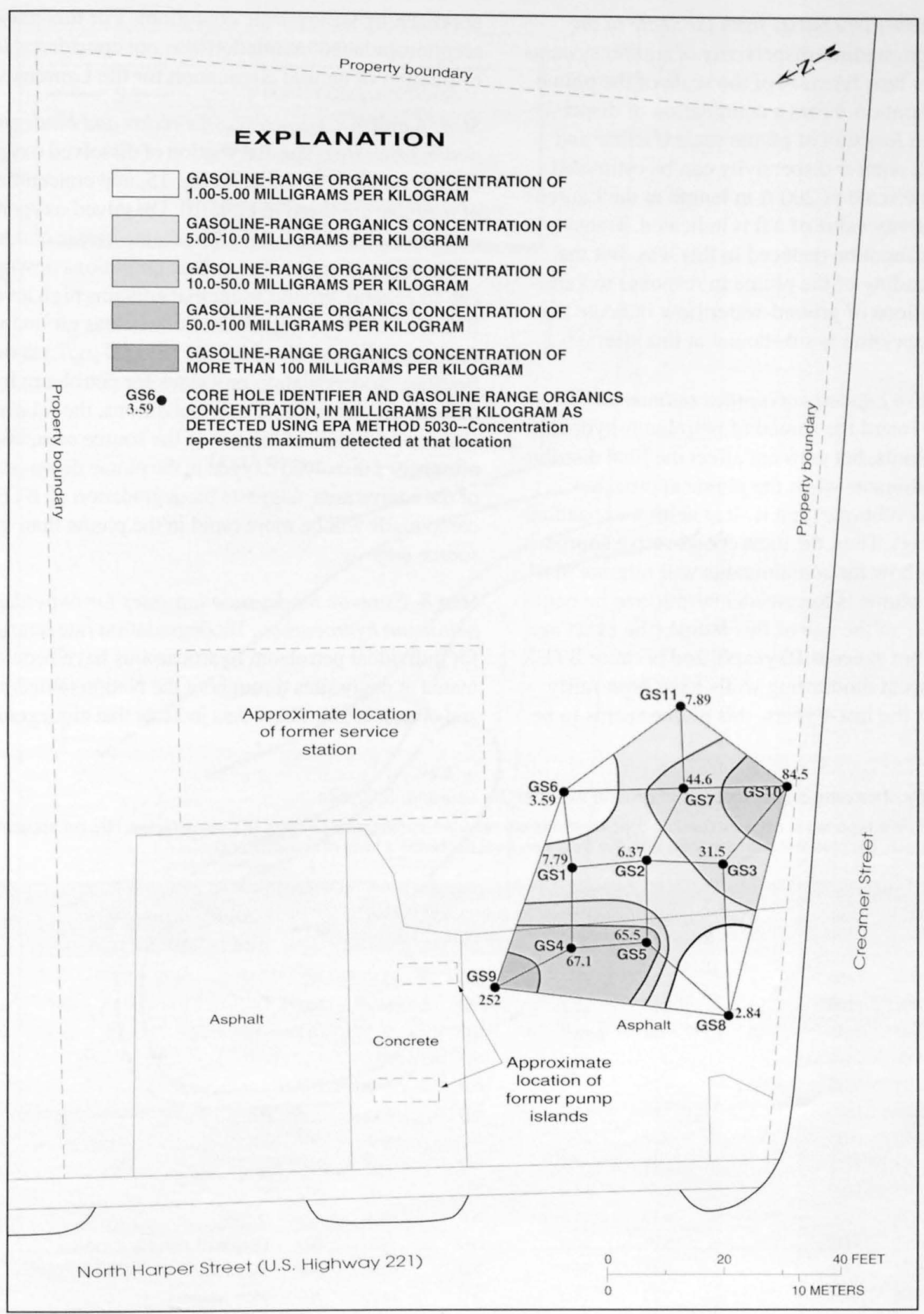

Base modified from Alpha

Environmental Sciences. Inc., 1997

Figure 14. Approximate distribution of gasoline-range organics (GRO) at the Laurens, S.C., site. 
Step 4-Estimate dispersivity from the scale of the plume. The longitudinal dispersivity of aquifer systems is observed to be a function of the scale of the plume under consideration. From a compilation of dispersivity values as a function of plume scale (Gelhar and others, 1992), aquifer dispersivity can be estimated. Given a plume scale of $200 \mathrm{ft}$ in length at the Laurens site, a dispersivity value of $2 \mathrm{ft}$ is indicated. Transverse dispersivity cannot be deduced in this way, but the apparent spreading of the plume in response to variations in directions of ground-water flow indicate that transverse dispersion is substantial at this site.

\section{Step 5-Sorptive capacity of aquifer sediments.}

Sorption can retard the spread of petroleum-hydrocarbon contaminants, but does not affect the final distribution of contaminants when the plume approaches steady-state conditions (that is, it is neither expanding nor contracting). Thus, the most conservative approach to evaluating how far contaminants will migrate in a contaminant plume is to consider sorption to be negligible. Because of the age of this plume (the exact age is unknown, but exceeds 10 years), and because BTEX concentrations at monitoring wells have been fairly constant over the last 4 years, this plume seems to be approaching steady-state conditions. For this reason, sorption-induced retardation was not considered in the evaluation of natural attenuation for the Laurens site.

Steps 6 and 7-Characterize the redox and biodegradation processes. The distribution of dissolved oxygen at the site (table 9) is shown in fig. 15, and concentrations of methane are listed in table 10. Dissolved oxygen concentrations less than $0.2 \mathrm{mg} / \mathrm{L}$ indicate anoxic conditions in the source area grading to oxic conditions downgradient. In general, ground water that contains high levels of BTEX $(>10,000 \mu \mathrm{g} / \mathrm{L})$ is anoxic, whereas ground water containing low levels of BTEX $(<1,000 \mu \mathrm{g} / \mathrm{L})$ is oxic. Because biodegradation processes for petroleum hydrocarbons are faster under oxic conditions, the relative absence of dissolved oxygen in the source area, and the presence of dissolved oxygen in the plume downgradient of the source area, suggests biodegradation of BTEX compounds will be more rapid in the plume than in the source area.

\section{Step 8-Estimate biodegradation rates for individual} petroleum hydrocarbon. Biodegradation rate constants for individual petroleum hydrocarbons have been estimated at many sites throughout the Nation (Wiedemeier and others, 1996). These data indicate that biodegradation

Table 9. Redox chemistry characteristics of ground water at the Laurens, S.C., site

[Water temperature is reported in degrees Celsius; concentrations are reported in milligrams per liter; ND, not detected; NA, not applicable; $>$ greater than; trace, denotes that concentration is above detection level but below a level of accurate analysis]

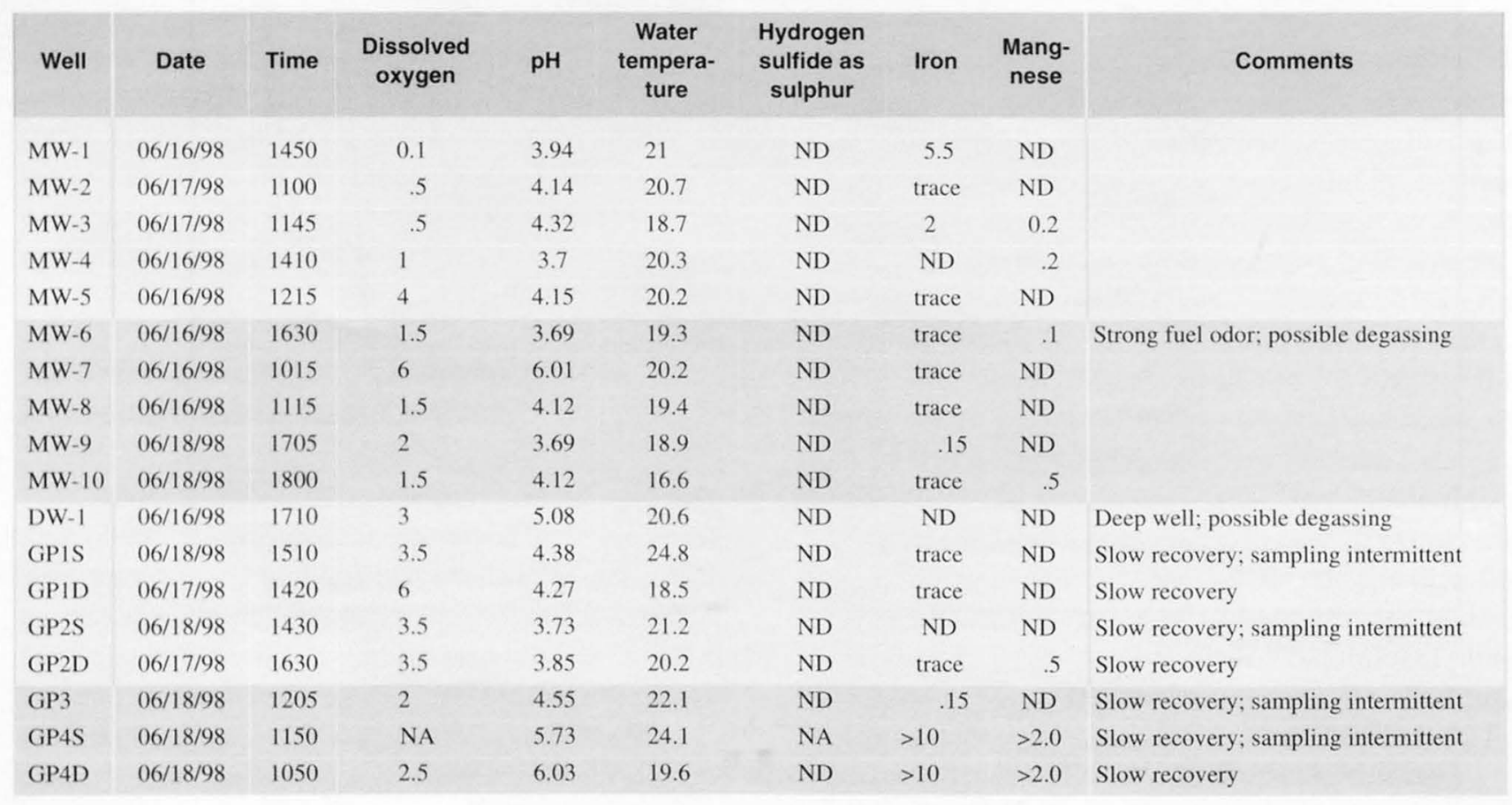




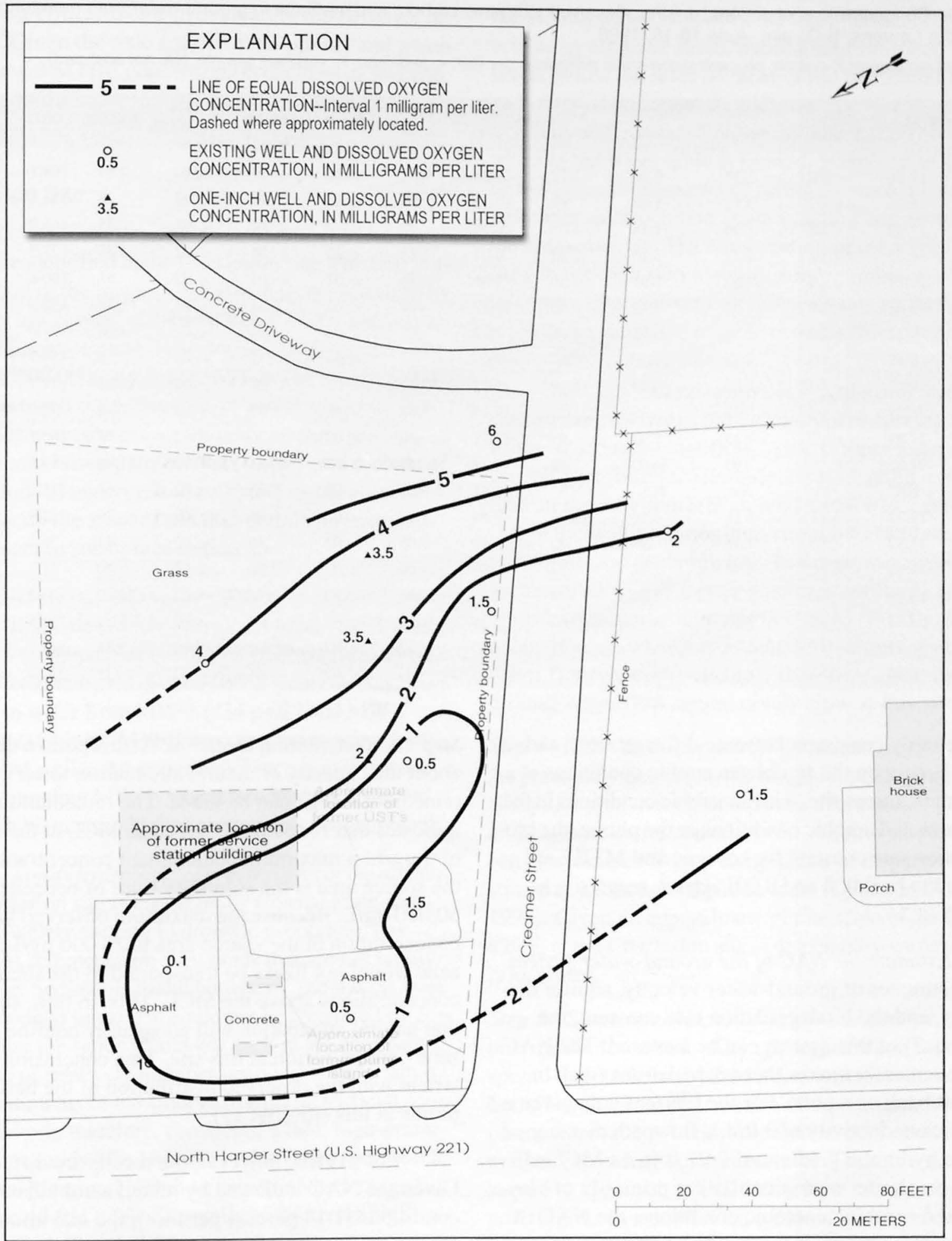

Base modified from Alpha

Environmental Sciences, Inc., 1997

Figure 15. Distribution of dissolved oxygen at the Laurens, S.C., site. 
Table 10. Concentrations of cations, anions, dissolved inorganic carbon, and methane in ground water from monitoring wells at the Laurens, S.C., site, June 16-18, 1998

[DIC, dissolved inorganic carbon; concentrations are in milligrams per liter; <, less than; R, replicate sample; NA, not analyzed]

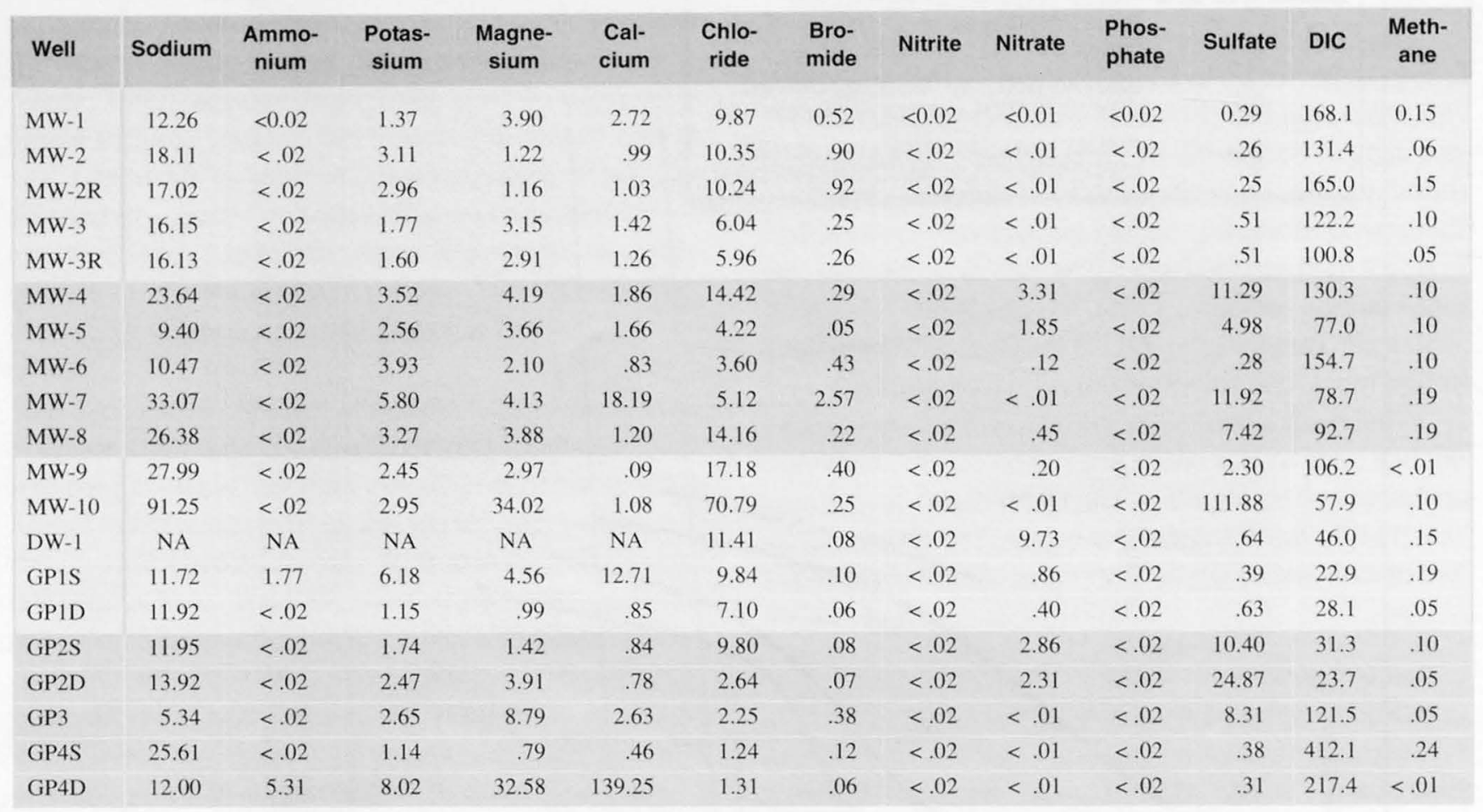

rates are fairly consistent between different sites, and depend largely on the aerobic/anaerobic conditions at a site. At the Laurens site, with anaerobic conditions in the source area and aerobic conditions in the plume, the biodegradation rate constant for benzene and MTBE are estimated to be 0.005 and 0.001 days $^{-1}$, respectively (table 3).

Step 9-Estimate the NAC of the ground-water system. Given estimates of ground-water velocity, aquifer dispersivity, and the biodegradation rate constant, the NAC (eq. 7) of this system can be assessed. The NAC tool conveniently makes these calculations (disk in pocket at back of report). For the Laurens site, given a hydraulic conductivity of $3 \mathrm{ft} / \mathrm{d}$, a flowpath distance of $200 \mathrm{ft}$, a hydraulic gradient of $0.01 \mathrm{ft} / \mathrm{ft}$, an MCL of $5 \mu \mathrm{g} / \mathrm{L}$, an aquifer matrix consisting primarily of clay, and mixed aerobic/anaerobic conditions, the NAC of this system for benzene is estimated to be 5.28 percent per foot of flowpath. Similarly, for MTBE, the NAC is estimated to be 1.14 percent per foot of flowpath. The difference between the NAC for benzene and MTBE reflects the lower biodegradation rate constant for MTBE. This is relatively efficient natural attenuation for benzene, and somewhat lower for MTBE.
Step 10-Remediation Decision. At this point a decision about the capacity of natural attenuation to serve as a remedial strategy can be made. The remediation tool indicates that for benzene, given an MCL at the stream of $5 \mu \mathrm{g} / \mathrm{L}$, a maximum contaminant concentration in the source area is the solubility limit of benzene, or $60,000 \mu \mathrm{g} / \mathrm{L}$. Because the maximum observed benzene concentration in the source area is $28,000 \mu \mathrm{g} / \mathrm{L}$, benzene would not likely be transported to the stream at concentrations above the MCL. This, in turn, suggests that natural attenuation will adequately confine benzene contamination at this site. This conclusion is consistent with the observed distribution of the benzene plume at this site (fig. 11).

For MTBE, however, the results are different. Given the NAC indicated by mixed aerobic/anaerobic conditions ( 1.14 percent per foot), the maximum allowable concentration of MTBE in the source is calculated to be only $48.95 \mu \mathrm{g} / \mathrm{L}$. This is well below the measured MTBE concentration of $64,178 \mu \mathrm{g} / \mathrm{L}$ in the source area. However, if aerobic conditions are specified, the maximum allowable MTBE concentration in the source area is calculated to be $1,276,226 \mu \mathrm{g} / \mathrm{L}$. Clearly, dissolved oxygen concentrations in ground 
water are a critical factor in evaluating the behavior at this site. Given the oxic nature of the plume, and given the observed MTBE concentration declines at this site, aerobic conditions seem to be representative, and MTBE will not impact the stream.

\section{Charleston Site}

Step 1-Delineation of source area. Two source-area locations were identified at the Charleston site. The first is at the location of the former UST, which is characterized by relatively low levels $(<2,010 \mu \mathrm{g} / \mathrm{kg})$ of GRO. The second is near the former pump island where concentrations in excess of $100,000 \mu \mathrm{g} / \mathrm{kg}$ were found. The approximate distribution and concentrations of petroleum hydrocarbons in the source areas are shown in figure 16. This delineation is based partly on site history and records of the locations of underground tanks and distribution lines, and partly on the amount of GRO petroleum hydrocarbons present in subsurface sediments.

\section{Step 2-Define areal and vertical extent of contaminant} plume. The Charleston site is typical of many UST sites in South Carolina in that it is difficult to delineate a distinct plume of contaminated ground water. Benzene was detected in water from MW-1 $(434 \mu \mathrm{g} / \mathrm{L})$ and MW-2 $(210 \mu \mathrm{g} / \mathrm{L})($ table 8$)$. MTBE was detected in water from MW-1 $(161 \mu \mathrm{g} / \mathrm{L})$. An important observation is that the wells surrounding MW-4, where free product is present, do not exhibit measurable concentrations of contaminants.

\section{Step 3-Quantify hydrologic characteristics of the aquifer:} The Charleston site is underlain by Coastal Plain sediments of widely varying hydrologic properties. The uppermost sediments are silty sands that are not highly permeable. Sediments found between 7 and $9 \mathrm{ft}$ bls were water-saturated sands that could not be recovered by coring because the sands would not pack in the core barrel. This zone of relatively high permeability is underlain by clayey sediments of the Cooper Marl. The surficial aquifer framework, therefore, consists of a thin, high-permeability zone sandwiched between relatively impermeable sediments. Measured hydraulic conductivities ranged from 20 to $40 \mathrm{ft} / \mathrm{d}$ (table 5), and these relatively high values probably reflect the high-permeability zone present at 7 to $9 \mathrm{ft}$ bls.

A conceptual model of this hydrologic system is shown in figure 17. The low-permeability sediments of the Cooper Marl act as a lower confining bed. The lowpermeability sands from land surface to $7 \mathrm{ft}$ bls have trapped petroleum hydrocarbons that slowly leach into the ground water. However, the high-permeability zone acts as an effective drain, maintaining saturated water levels below the level of most of the petroleum-hydrocarbon contamination. In addition, because the site is overlain with macadam blacktop, the infiltration of water to the water table is limited. However, in periods of high precipitation, water levels rise into the zone of petroleum-hydrocarbon contamination and mobilize the contaminants. The combination of relatively fast flow in the high-permeability zone, combined with relatively little delivery of contaminants to the saturated zone, limits the migration of dissolved petroleum hydrocarbons at the site.

Rates of ground-water flow at this site vary considerably between the different permeability zones. Rates of ground-water flow in the Cooper Marl are probably negligible. Similarly, rates of ground-water flow in the silty sands from land surface to $7 \mathrm{ft}$ bls (when the water table is high enough to saturate these sediments) are probably low. In the zone of high permeability ( 7 to $9 \mathrm{ft}$ bls), where permeability is about $20 \mathrm{ft} / \mathrm{d}$, a hydraulic gradient of $0.0042 \mathrm{ft} / \mathrm{ft}$ (fig. 9), and an aquifer matrix of sand and clay, the rates of groundwater flow are approximately $0.31 \mathrm{ft} / \mathrm{d}$. Thus, rates of ground-water flow are relatively slow at this site.

Step 4-Estimate dispersivity from the scale of the plume. As previously described, the longitudinal dispersivity of an aquifer system is observed to be a function of the scale of the plume under consideration. Aquifer dispersivity can be estimated from a compilation of dispersivity values as a function of plume scale (Gelhar and others, 1992). Given an approximate plume scale of $20 \mathrm{ft}$ in length at the Charleston site, a dispersivity value of $1 \mathrm{ft}^{-1}$ is indicated.

Step 5 -Sorptive capacity of aquifer sediments. As previously described, although sorption can retard the spread of petroleum hydrocarbon contaminants, it does not affect the final distribution of contaminants when a plume approaches steady-state conditions (that is, it is neither expanding nor contracting). Thus, the most conservative approach to evaluating how far contaminants will migrate in a contaminant plume is to consider sorption to be negligible. The exact age of this plume is unknown, but exceeds 10 years, and BTEX concentrations at monitoring wells have been fairly constant over the last 4 years, which indicates that the plume may to be approaching steady-state conditions. For this reason, sorption-induced retardation was not considered in the evaluation of natural attenuation for the Charleston site. 


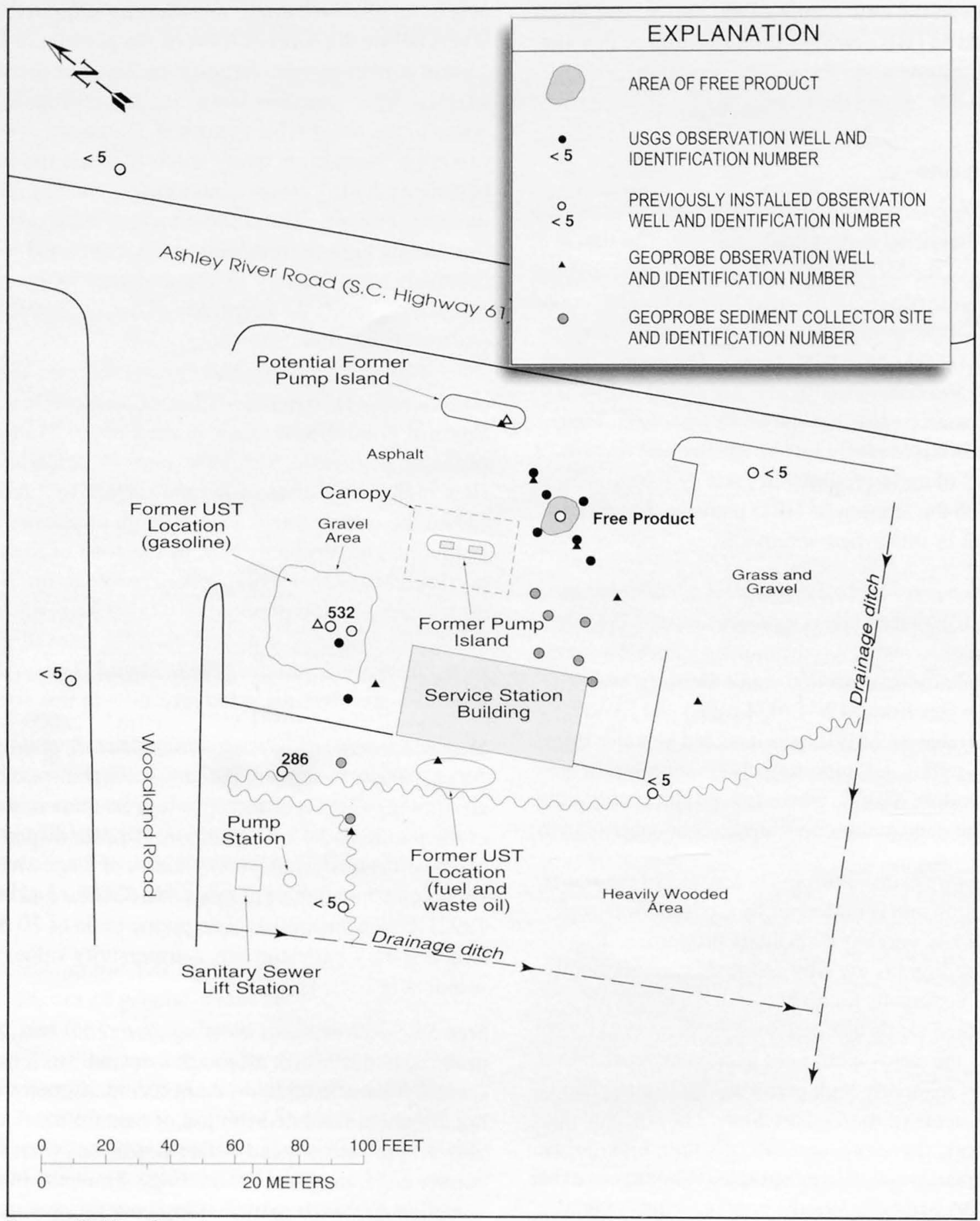

Base modified from General

Engineering Laboratories, 1993

Figure 16. Approximate distribution of gasoline-range organics (GRO) at the Charleston, S.C., site. 


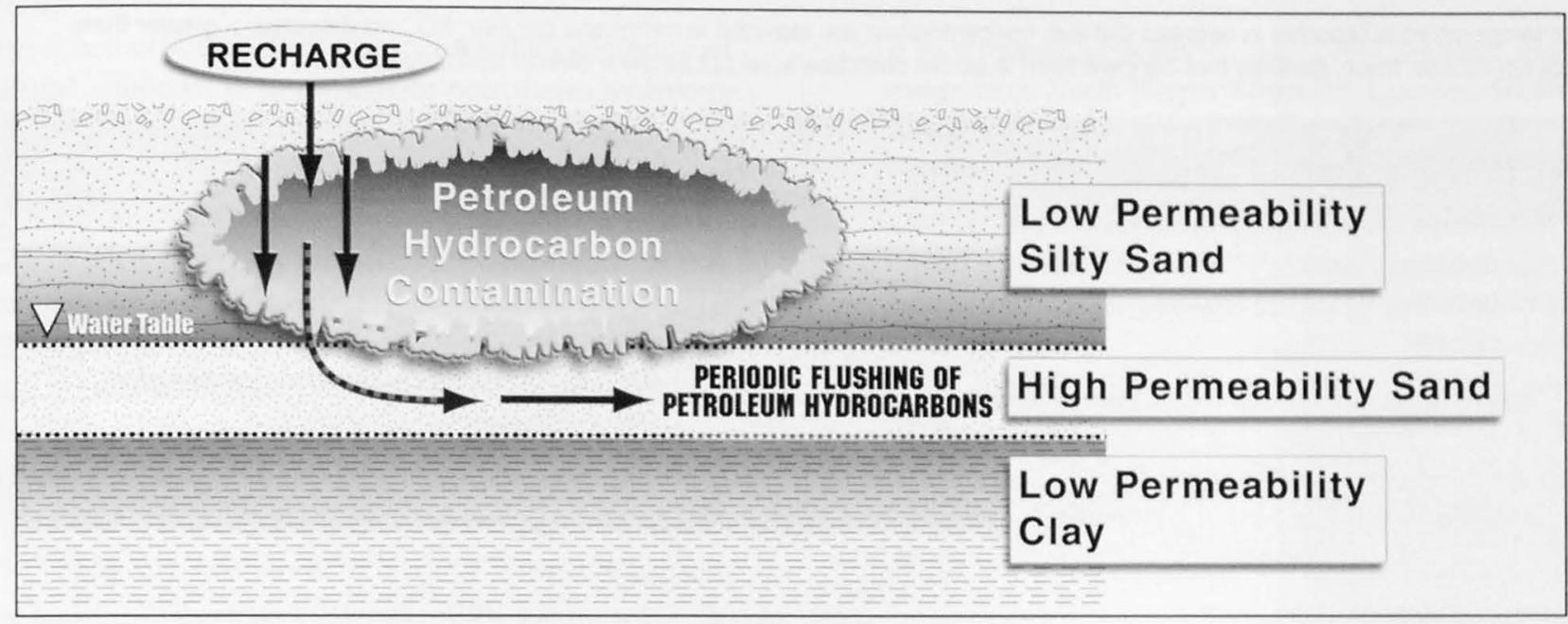

Figure 17. Conceptualization of hydrologic conditions and mobilization of petroleum hydrocarbons entrained in soils at the Charleston, S.C., site.

Steps 6 and 7-Characterize the redox and biodegradation processes. Dissolved oxygen is present at low concentrations throughout the site (table 11), and relatively high concentrations of methane are present in the contaminated zone (table 12). Low-permeability, greenish sediments of the Cooper Marl are probably anoxic. The presence of dissolved oxygen, the lack of hydrogen sulfide, and the presence of relatively high concentrations of iron indicate a mix of aerobic and anaerobic conditions at this site.

\section{Step 8-Estimate biodegradation rates for individual} petroleum hydrocarbon. Biodegradation rate constants for individual petroleum hydrocarbons have been estimated at many sites throughout the Nation (Wiedemeier and others, 1996). These data indicate that biodegradation rates are fairly consistent between different sites, and depend largely on the aerobic/anaerobic conditions at a site. At the Charleston site, with a mix of aerobic and anaerobic conditions, biodegradation rate constants for particular compounds can be estimated (table 3 ).

\section{Step 9-Estimate the NAC of the ground-water system.}

Given estimates of ground-water velocity, aquifer dispersivity, and the biodegradation rate constant, the NAC (eq. 7) of this system can be assessed. The NAC tool conveniently makes these calculations (disk in pocket at back of report). For benzene transport at the Charleston site, given a hydraulic conductivity of $18 \mathrm{ft} / \mathrm{d}$, a flowpath distance of $50 \mathrm{ft}$, a hydraulic gradient of $0.0042 \mathrm{ft} / \mathrm{ft}$, an
MCL of $5 \mu \mathrm{g} / \mathrm{L}$, an aquifer matrix consisting of sand and clay, and mixed aerobic/anaerobic conditions, the NAC is estimated to be 1.58 percent per foot of flowpath. Similarly, for MTBE, the NAC is estimated to be 0.32 percent per foot of flowpath. The difference between the NAC for benzene and MTBE reflects the lower biodegradation rate constant for MTBE. This is relatively efficient natural attenuation for benzene, and somewhat lower for MTBE.

Step 10-Remediation Decision. At this point, a decision about the capacity of natural attenuation to serve as part of site remediation can be made. The remediation tool indicates that for benzene, given an MCL at the stream of $5 \mu \mathrm{g} / \mathrm{L}$, a maximum contaminant concentration in the source area is just $11.0 \mu \mathrm{g} / \mathrm{L}$. Because the maximum observed benzene concentration in the source area is $434 \mu \mathrm{g} / \mathrm{L}$, benzene could possibly be transported to the stream at concentrations above the MCL. This, in turn, suggests that natural attenuation may not adequately confine benzene contamination at this site.

The results are similar for MTBE. Given the NAC indicated by mixed aerobic/anaerobic conditions ( 0.32 percent per foot), the maximum allowable concentration of MTBE in the source is calculated to be just $5.87 \mu \mathrm{g} / \mathrm{L}$. This is below the measured MTBE concentration of $161 \mu \mathrm{g} / \mathrm{L}$ in the source area, and suggests that MTBE transport to the point of contact is possible. 
Table 11. Redox chemistry characteristics of ground water at the Charleston, S.C., site

[Water temperature is reported in degrees Celsius; concentrations are reported in milligrams per liter; ND, not detected; > greater than; NA, not applicable; trace, denotes that concentration is above detection level but below a level of accurate analysis]

\begin{tabular}{|c|c|c|c|c|c|c|c|c|c|}
\hline Well & Date & Time & $\begin{array}{c}\text { Dissolved } \\
\text { oxygen }\end{array}$ & $\mathrm{pH}$ & $\begin{array}{l}\text { Water } \\
\text { tempera- } \\
\text { ture }\end{array}$ & $\begin{array}{l}\text { Hydrogen } \\
\text { sulfide as } \\
\text { sulphur }\end{array}$ & Iron & $\begin{array}{l}\text { Mang- } \\
\text { nese }\end{array}$ & Comments \\
\hline MW-1 & $06 / 25 / 98$ & 1330 & ND & 6.34 & 22.1 & 0.1 & $>10$ & ND & \\
\hline MW-2 & $06 / 24 / 98$ & 1520 & 0.05 & 6.28 & 20.3 & .1 & 6 & 0.4 & \\
\hline MW-3 & $06 / 24 / 98$ & 1125 & .9 & 3.98 & 25.9 & ND & .2 & ND & \\
\hline MW-4 & $06 / 25 / 98$ & 1100 & NA & NA & $\mathrm{NA}$ & NA & NA & NA & Free product, black, gasoline odor \\
\hline MW-5 & $06 / 24 / 98$ & 1245 & .5 & 6.23 & 23.4 & ND & 1.5 & 1 & \\
\hline MW-6 & $06 / 24 / 98$ & 1355 & .7 & 6.41 & 20.6 & ND & 6.5 & ND & Roots, iron, and mud-screen breached? \\
\hline MW-7 & $06 / 24 / 98$ & 1600 & .3 & 6.62 & 20.9 & ND & .6 & ND & \\
\hline MW-8 & $06 / 24 / 98$ & 1045 & .15 & 4.56 & 26.7 & ND & $>10$ & ND & \\
\hline PW-1 & $06 / 25 / 98$ & 1240 & 7 & 7.27 & 22.2 & ND & trace & ND & \\
\hline GP-1 & $06 / 24 / 98$ & NA & NA & NA & NA & NA & NA & NA & Dry well \\
\hline GP-2 & $06 / 24 / 98$ & NA & NA & NA & NA & NA & NA & NA & Dry well \\
\hline GP-3 & $06 / 24 / 98$ & 1210 & NA & NA & NA & NA & NA & NA & Dry well \\
\hline GP-4 & $06 / 24 / 98$ & NA & NA & NA & NA & NA & NA & NA & Dry; sump water has strong fuel odor \\
\hline GP-5 & $06 / 24 / 98$ & 1650 & NA & NA & NA & NA & NA & NA & Dry well \\
\hline GP-6 & $06 / 25 / 98$ & NA & NA & NA & NA & NA & NA & NA & Dry well \\
\hline GP-7 & $06 / 24 / 98$ & 1700 & NA & NA & NA & NA & NA & NA & Free product in sump, weathered gasoline \\
\hline GP-8 & $06 / 25 / 98$ & NA & NA & $\mathrm{NA}$ & NA & NA & NA & NA & Dry, petroleum odor \\
\hline
\end{tabular}

Table 12. Concentrations of cations, anions, dissolved inorganic carbon, and methane in ground water from monitoring wells at the Charleston, S.C., site, June 24-25, 1998

[DIC, dissolved inorganic carbon; concentrations are in milligrams per liter; <, less than; R, replicate sample; NA, not analyzed]

\begin{tabular}{|lccccccccccccc} 
Well & Sodium & $\begin{array}{c}\text { Ammo- } \\
\text { nium }\end{array}$ & $\begin{array}{c}\text { Potas- } \\
\text { sium }\end{array}$ & $\begin{array}{c}\text { Magne- } \\
\text { sium }\end{array}$ & $\begin{array}{c}\text { Cal- } \\
\text { cium }\end{array}$ & $\begin{array}{c}\text { Chlo- } \\
\text { ride }\end{array}$ & $\begin{array}{c}\text { Bro- } \\
\text { mide }\end{array}$ & Nitrite & $\begin{array}{c}\text { Nitrate } \\
\text { Phos- } \\
\text { phate }\end{array}$ & $\begin{array}{c}\text { Sulfate } \\
\text { DIC }\end{array}$ & $\begin{array}{c}\text { Meth- } \\
\text { ane }\end{array}$ \\
MW-1 & 143.50 & $<0.02$ & 6.61 & 8.21 & 185.46 & 72.40 & 0.71 & $<0.02$ & $<0.01$ & $<0.02$ & 23.82 & 542.0 & 7.14 \\
MW-1R & 133.93 & $<.02$ & 6.39 & 8.85 & 203.36 & 72.89 & .71 & $<.02$ & $<.01$ & $<.02$ & 23.80 & 392.5 & 5.44 \\
MW-2 & 108.37 & $<.02$ & 8.31 & 11.77 & 154.90 & 29.42 & .32 & $<.02$ & $<.01$ & $<.02$ & 32.94 & 364.2 & 1.17 \\
MW-2R & 115.97 & $<.02$ & 9.27 & 12.55 & 147.24 & 30.00 & .31 & $<.02$ & $<.01$ & $<.02$ & 32.85 & 382.8 & 1.07 \\
MW-3 & 26.17 & $<.02$ & 4.41 & 4.38 & 3.05 & 6.97 & .13 & $<.02$ & $<.01$ & $<.02$ & 38.73 & 101.8 & .10 \\
MW-4 & NA & NA & NA & NA & NA & NA & NA & NA & NA & NA & NA & NA & NA \\
MW-5 & 75.67 & $<.02$ & 8.22 & 10.59 & 232.34 & 15.75 & .49 & $<.02$ & $<.01$ & $<.02$ & 40.69 & 572.2 & .10 \\
MW-6 & 137.26 & $<.02$ & 11.97 & 11.81 & 183.86 & 52.44 & .60 & $<.02$ & $<.01$ & $<.02$ & 32.60 & 549.4 & .24 \\
MW-7 & 134.80 & $<.02$ & 18.05 & 20.02 & 176.32 & 40.05 & .29 & $<.02$ & $<.01$ & $<.02$ & 41.10 & 406.0 & .19 \\
MW-8 & 46.44 & $<.02$ & 12.98 & 12.59 & 44.53 & 23.08 & 2.34 & $<.02$ & $<.01$ & $<.02$ & 122.75 & 226.4 & .19 \\
PW-1 & 389.85 & $<.02$ & 47.72 & 25.31 & 42.55 & 115.63 & .53 & $<.02$ & $<.01$ & $<.02$ & 79.41 & 288.7 & .19 \\
\hline
\end{tabular}




\section{SUMMARY AND CONCLUSIONS}

A methodology for assessing the efficiency of natural attenuation to remediate petroleum hydrocarbon-contaminated ground water was developed and applied to two sites in South Carolina. This methodology outlines the hydrologic, geochemical, and biologic data needed to assess the efficiency of natural attenuation, shows how this data can be integrated and used to compute the capacity of the system to lower contaminant concentrations along aquifer flowpaths, and provides an interactive computer tool for making preliminary assessments of the natural attenuation capacity.

The use of this methodology was illustrated by evaluating two sites in South Carolina. The Laurens site located in the Piedmont Physiographic Province is underlain by a clayey saprolitic aquifer. Concentrations of benzene $(28,300 \mu \mathrm{g} / \mathrm{L})$, and MTBE $(64,178 \mu \mathrm{g} / \mathrm{L})$ are relatively high in the source area but decrease rapidly downgradient. The natural attenuation capacity of this system (the capacity of the aquifer to decrease contaminant concentrations along the flowpath) for benzene, given the observed aerobic conditions of the plume, is approximately 5.28 percent per foot of flowpath, which is sufficient to completely degrade benzene before it discharges to a small stream about $200 \mathrm{ft}$ downgradient. Although lower for MTBE (approximately 1.14 percent per foot of flowpath), the natural attenuation capacity seems to be sufficient to degrade MTBE before it reaches the stream. Thus, at the Laurens site, natural attenuation processes seem sufficient to prevent transport of contaminants from the source area to the nearest point of contact.

The Charleston site located in the Coastal Plain Physiographic Province is underlain by sand and clay that is characterized by relatively low rates of groundwater flow $(0.3 \mathrm{ft} / \mathrm{d})$; the flow system exhibits a mix of aerobic and anaerobic conditions. The estimated natural attenuation capacity for benzene is approximately 1.58 percent per foot, and 0.32 percent per foot for MTBE. This indicates that maximum contaminant concentrations in the source area should not exceed $11.0 \mu \mathrm{g} / \mathrm{L}$ for benzene, or $5.87 \mu \mathrm{g} / \mathrm{L}$ for MTBE in order for natural attenuation to fully protect adjacent points of ground-water discharge. Because the observed maximum contaminant concentrations in the source area are higher than these values, natural attenuation may not be an adequate stand-alone remedial strategy at the Charleston site.

\section{REFERENCES}

Alpha Environmental Sciences, Inc., 1996, Standard limited assessment, North Harper Street BP, Laurens, South Carolina: Consultant's report to the South Carolina Department of Health and Environmental Control, 23 p.

---- 1997, Rapid assessment report, North Harper Street BP, Laurens, South Carolina: Consultant's report to the South Carolina Department of Health and Environmental Control, 23 p.

American Public Health Association, American Water Works Association, and the Water Environment Federation, 1998, Standard methods for the examination of water and wastewater (20th ed.): Washington, D.C., American Public Health Association, 1142 p.

American Society for Testing and Materials, 1994, Standard test methods for low level dissolved oxygen in water: Philadelphia, Annual Book of Standards, Standard D 5543-94.

Baedecker, M.J., Cozzarelli, I.M., Eganhouse, R.P., Siegel, D.I., and Bennett, P.C., 1993, Crude oil in a shallow sand and gravel aquifer, III. Biogeochemical reactions and mass balance modeling in anoxic ground water: Applied Geochemistry, v. 8, p. 569-586.

Baedecker, M.J., Siegel, D.I., Bennett, P.C., and Cozzarelli, I.M.,1988, The fate and effects of crude oil in a shallow aquifer: 1. The distribution of chemical species and geochemical facies, in Mallard, G.E., and Ragone, S.E., eds., U.S. Geological Survey Toxic Substances Hydrology Program, Proceedings of the Technical Meeting, Phoenix, Arizona, September 26-30, 1988: U.S. Geological Survey Water-Resources Investigations Report 88-4220, p. 13-20.

Barker, J.F., Patrick, G.C., and Major, D., 1987, Natural attenuation of aromatic hydrocarbons in a shallow sand aquifer: Ground Water Monitoring Review, v. 7 , p. 64-71.

Bekins, B.A., Warren, E., and Godsy, E.M., 1998, A comparison of zero-order, first-order, and monod biotransformation models: Ground Water, v. 36, p. 261-268.

Bouwer, Herman, 1989, The Bouwer and Rice slug test-An update: Ground Water, v. 27, no. 3, p. 304-309.

Bouwer, Herman, and Rice, R.C., 1976, A slug test for determining hydraulic conductivity of unconfined aquifers with completely or partially penetrating wells: Water Resources Research, v. 12, p. 423-428.

Bradley, P.M., and Chapelle, F.H., 1997, Kinetics of DCE and $\mathrm{VC}$ mineralization under methanogenic and $\mathrm{Fe}(\mathrm{III})-$ reducing conditions: Environmental Science and Technology, v. 30, p. 1984-2086. 
Campbell, B.G., Conlon, K.J., Mirecki, J.E., and Petkewich, M.D., 1997, Evaluation of aquifer storage and recovery in the Santee Limestone/Black Mingo aquifer near Charleston, South Carolina, 1993-95: U.S. Geological Survey Water-Resources Investigations Report 96-4183, 89 p.

Chapelle, F.H., Bradley, P.M., Lovley, D.R., and Vroblesky, D.A., 1996, Measuring rates of biodegradation in a contaminated aquifer using field and laboratory methods: Ground Water, v. 34, p. 691-698.

Chapra, S.C., 1996, Surface water-quality monitoring: New York, McGraw Hill, 844 p.

Charbeneau, R.J., and Daniel, D.E., 1993, Contaminant transport in unsaturated flow, in Maidment, D.R., ed., Handbook of Hydrology: New York, McGraw Hill, p. 151 .

Chemetrics, Inc., 1984, Power plant manual (1st ed.): Chemetrics, Inc., 169 p.

Cherry, R.N., and Badr, A.W., 1998, South Carolina water plan, goals and guidelines for management of the State's water resources: Columbia, South Carolina Department of Natural Resources, Land, Water and Conservation Division, $62 \mathrm{p}$.

Church, C.D., Isabelle, L.M., Pankow, J.F., Rose, D.L., and Tratnyek, P.G., 1997, Method for the determination of methyl tert-butyl ether and its degradation products in water: Environmental Science and Technology, v. 31, no. 12 , p. $3723-3726$.

Cozzarelli, I.M., Eganhouse, R.P., and Baedecker, M.J., 1988, The fate and effects of crude oil in a shallow aquifer: II. Evidence of anaerobic degradation of monoaromatic hydrocarbons, in Mallard, G.E., and Ragone, S.E., eds., U.S. Geological Survey Toxic Substances Hydrology Program, Proceedings of the Technical Meeting, Phoenix, Arizona, September 26-30, 1988: U.S. Geological Survey Water-Resources Investigations Report 88-4220, p. 21-33.

Daniel, C.C., III, and Harned, D.A., 1998, Ground-water recharge to and storage in the regolith-fractured crystalline rock aquifer system, Guilford County, North Carolina: U.S. Geological Survey Water-Resources Investigations Report 97-4140, 65 p.

Freeze, R.A., and Cherry, J.A., 1979, Groundwater: Englewood Cliffs, N.J., Prentice-Hall, 604 p.

Gelhar, L.W., Welty, C., and Rehfeldt, K.R., 1992, A critical review of data on field-scale dispersion in aquifers: Water Resources Research, v. 28, p. 955-1974.

General Engineering Laboratories, 1991, Underground storage tank closure assessment, former Oasis service station, Charleston, South Carolina: Consultant's report to the South Carolina Department of Health and Environmental Control, 5 p.
1992, Expanded assessment plan, former Oasis service station, Charleston, South Carolina: Consultant's report to the South Carolina Department of Health and Environmental Control, $13 \mathrm{p}$.

-1993a, Expanded assessment report, former Oasis service station, Carolina: Consultant's report to the South Carolina Department of Health and Environmental Control, 19 p.

1993b, Quarterly monitoring update, former Oasis service station, Charleston, South Carolina, June 1993: Consultant's report to the South Carolina Department of Health and Environmental Control, 2 p.

- 1993c, Quarterly monitoring update, former Oasis service station, Charleston, South Carolina, November 1993: Consultant's report to the South Carolina Department of Health and Environmental Control, 2 p.

- 1994, Quarterly monitoring update, former Oasis service station, Charleston, South Carolina, January 1994: Consultant's report to the South Carolina Department of Health and Environmental Control, 2 p.

Gilbert, T.W., Behymer, T.D., and Castaneda, H.B., 1982, Determination of dissolved oxygen in natural and wastewaters: American Laboratory, March 1982, p. 119-134.

Hadley, P.W., and Armstrong, R., 1991, Where's the benzene?-Examining California ground-water quality surveys: Ground Water, v. 29, p. 35-40.

Landmeyer, J.E., Chapelle, F.H., Bradley, P.M., Pankow, J.F., Church, C.D., and Tratnyek, P.G., 1998, Fate of MTBE relative to benzene in a gasoline-contaminated aquifer (1993-98): Ground Water Monitoring \& Remediation, v. 18 , no. 4, p. 93-102.

Lovley, D.R., Baedecker, M.J., Lonergan, D.J., Cozzarelli, I.M., Phillips, E.J.P., and Siegel, D.I., 1989, Oxidation of aromatic contaminants coupled to microbial iron reduction: London, Nature, v. 339, p. 297-299.

McCartan, Lucy, Weems, R.E., and Lemon, E.M., Jr., 1980, The Wando Formation (Upper Pleistocene) in the Charleston, South Carolina, area, in Sohl, N.F., and Wright, W.B., Changes in stratigraphic nomenclature by the U.S. Geological Survey, 1979: U.S. Geological Survey Bulletin 1502-A, p. A110-A116.

1990, Quaternary stratigraphy in the vicinity of Charleston, South Carolina, and its relationship to local seismicity and regional tectonism: U.S. Geological Survey Professional Paper 1367-A, 39 p.

McCartan, Lucy, Lemon, E.M., Jr., and Weems, R.E., 1984 , Geologic map of the area between Charleston and Orangeburg, South Carolina: U.S. Geological Survey Miscellaneous Investigations Map Series I-1492, scale 1:250,000, 1 sheet. 
National Oceanic and Atmospheric Administration, 1999, Climatological data annual summary, South Carolina, 1998: Asheville, N.C., v. 101, no. 13, 19 p.

Nelson, A.E., Horton, J.W., Jr., and Clarke, J.W., 1998, Geologic map of the Greenville $1^{\circ} \times 2^{\circ}$ quadrangle, Georgia, South Carolina, and North Carolina: U.S. Geological Survey Miscellaneous Investigations Map Series I-2175, scale $1: 250,000,1$ sheet.

Newcome, Roy, Jr., 1989, Ground-water resources of South Carolina's Coastal Plain-1988, an overview: South Carolina Water Resources Commission Report No. 167, $127 \mathrm{p}$.

Park, A.D., 1985, The ground-water resources of Charleston, Berkeley, and Dorchester Counties, South Carolina: South Carolina Water Resources Commission Report No. 139,146 p.

Schwartzenbach, R.P., and Westall, J., 1981, Transport of nonpolar organic compounds from surface water to ground water: Laboratory sorption studies: Environmental Science and Technology, v. 15, no. 11, p. 11-18.

South Carolina Department of Health and Environmental Control, 1995, Risk-based corrective action for petroleum releases, $11 \mathrm{p}$.

Squillace, P.J., Pankow, J.F., Korte, N.E., and Zogorski, J.S., 1997, Review of the environmental behavior and fate of methyl tert-butyl ether: Environmental Toxicology and Chemistry, v. 9, p. 1836-1844.

Stumm, W., and Morgan, J.J., 1981, Aquatic chemistry ( 2 d ed.): New York, John Wiley, 780 p.
U.S. Environmental Protection Agency, 1983, Methods for chemical analysis of water and waste: Washington, D.C., U.S. Environmental Protection Agency, $\mathrm{EPA} / 600 / 4-79 / 020$.

1986, Test methods for evaluating solid waste, Physi$\mathrm{cal} /$ chemical methods (3d ed.): Washington, D.C., U.S. Environmental Protection Agency, SW-846, 1919 p.

- 1996, Test methods for evaluating solid waste, Physi$\mathrm{cal} /$ chemical methods-Update III ( $3 \mathrm{~d}$ ed.): Washington, D.C., U.S. Environmental Protection Agency, SW-846. 1999, Final OSWER monitored natural attenuation policy: Washington, D.C., U.S. Environmental Protection Agency, Office of Solid Waste and Emergency Response, OSWER Directive 9200.4-17P.

Vroblesky, D.A., Robertson, J.F., and Rhodes, L.C., 1995, Stratigraphic trapping of shallow petroleum contamination: Ground-Water Monitoring and Remediation, v. 15, no. 2 , p. 177-183.

Ward, L.W., Blackwelder, B.W., Gohn, G.S., and Poore, R.Z., 1979, Stratigraphic revision of Eocene, Oligocene, and lower Miocene Formations of South Carolina: Geologic Notes, v. 23 , no. 1, p. 2-23.

Wiedemeier, T.H., Swanson, M.A., Wilson, J.T., Kampbell, D.H., Miller, R.N., and Hansen, J.E., 1996, Approximation of biodegradation rate constants for monoaromatic hydrocarbons (BTEX) in ground water: Ground Water Monitoring and Remediation, v. 16, p. 186-194.

Yazicigil, H., and Sendlein, L.V.A., 1981, Management of ground water contaminated by aromatic hydrocarbons in the aquifer supplying Ames, Iowa: Ground Water, v. 19 , no. 6 , p. $648-665$. 
